(1) 


\section{DESCUBRIENDO BALI ARTE Y EXOTISMO EN LA CRÓNICA HISPÁNICA}

Marisa Peiró Márquez

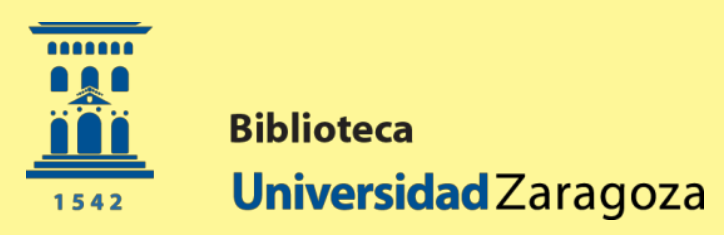




\section{EXPOSICIÓN}

Patrocina

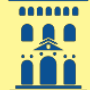

Vicerrectorado de

Cultura y Proyección Social

Universidad Zaragoza

Organiza

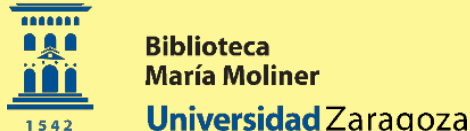

Facultad de

Filosofía y Letras

UniversidadZaragoza

\section{Comisaria}

Marisa Peiró Márquez

\section{Coordinación técnica y científica}

Marisa Peiró Márquez, David Almazán Tomás, Matilde Cantín Luna

Textos y catalogación

Marisa Peiró Márquez

Museografía, diseño y montaje

Marisa Peiró Márquez y Alba Finol Sola

\section{PUBLICACIÓN}

Coordinación y edición

Marisa Peiró Márquez

\section{Textos}

Marisa Peiró Márquez, Ricardo Martorell TéllezGirón, David Almazán Tomás

Matilde Cantín Luna

\section{Fotografías de la exposición}

Alba Finol Sola

\section{AGRADECIMIENTOS}

Biblioteca de la Universidad de Zaragoza, SEMETA de la Universidad de Zaragoza, Biblioteca Nacional de España, Archivo Miguel Covarrubias de la Universidad de las Américas de Puebla, Tropenmuseum (Ámsterdam), Ecos de Asia. Revista de divulgación sobre cultura asiática, familia Peiró Márquez, Adrián Navarro, Víctor Quero.

\section{(ब) $\odot \odot$}

Reconocimiento-NoComercialSinObraDerivada 


\section{ÍNDICE}

PRÓLOGO: AMPLIANDO HORIZONTES,

DESCUBRIENDO BALI

Por David AlmaZÁn Tomás y Matilde Cantín Luna

PRESENTACIÓN

6

Por MARISA PEIRó Márquez

EL DESCUBRIMIENTO DE BALI POR OCCIDENTE

Por MARISA PEIRó MÁRQUEZ

BALI ANTE EL MUNDO Y EL MUNDO EN BALI

Por MARISA PEIRÓ MárQUEZ

CRONISTAS HISPÁNICOS EN BALI

POR MARISA PEIRÓ MÁRQUEZ

LA VIDA COTIDIANA EN BALI

Por MARISA PEIRÓ MárqueZ

LA RELIGIÓN EN BALI

Por MARISA PEIRÓ MÁRQUEZ

LAS ARTES EN BALI

Por MARISA PEIRÓ MÁrqueZ

LAS ARTES ESCÉNICAS EN BALI

POR MARISA PEIRÓ MÁRQUEZ

LA GASTRONOMÍA BALINESA

POR MARISA PEIRÓ MÁRQUEZ

LAS DANZAS RITUALES EN LA ISLA DE BALI

POR RicARdo MARTORELl Y TÉLlEZ-GIRÓN

BIBLIOGRAFÍA RECOMENDADA

12

18

21

24

7

28

34

40

43

52 


\section{Prólogo: AmPLIANDO HORIZONTES, DESCUBRIENDO BALI}

Prof. David Almazán Tomás

Dpto. Historia del Arte

Universidad de Zaragoza

Matilde Cantín Luna

Directora de la Biblioteca María Moliner

Universidad de Zaragoza

Una de las críticas que podríamos hacer a los planes de estudios de las distintas titulaciones de la universidad española es un marcado eurocentrismo que deja fuera muchas culturas fundamentales para tener una visión panorámica. Los fuertes lazos históricos con América han servido para que configurar una larga tradición de americanistas, pero no ocurre lo mismo con otros continentes. En el mundo de la Historia del Arte, por las decisivas influencias que las artes de fuera de Europa han producido en nuestros más destacados artistas, pronto se ha visto la necesidad de ampliar horizontes hacia el arte otras lejanas regiones del mundo. La pasión por el arte japonés, en la segunda mitad del siglo XIX, en el llamado fenómeno del Japonismo, descubrió el arte de las lacas, cerámicas, marfiles, pinturas y estampas niponas. En la siguiente generación las máscaras y tallas del llamado Arte Negro influyeron decisivamente en el arte de los artistas de vanguardia, con Pablo Picasso como principal representante. Después, los surrealistas quedaron fascinados con el arte oceánico. Desde entonces, las principales exposiciones y estudios se han hecho eco de que para entender el desarrollo del arte europeo era necesario conocer también todo el arte que le influyó a lo largo del tiempo. En cierto modo, esta entrada en la historia del arte del arte japonés, del africano y del oceánico vino justificada por la esa influencia en el arte europeo y la presencia de grandes colecciones de estas exóticas tradiciones artísticas en nuestros museos, primero en los de etnología y, finalmente, también en los de arte.

Afortunadamente, la Universidad de Zaragoza tiene una larga tradición en estudios sobre arte islámico, precolombino, asiático y africano, y además son frecuentes las actividades culturales (exhibiciones, conferencias, semanas culturales, presentaciones de libros, etc.), que dinamizan la vida universitaria. Sin embargo, hay que reconocer que hay grandes regiones del mundo que injustamente quedan al margen. Siendo autocríticos no puede justificarse en absoluto que nuestros estudiantes no tengan acceso a la historia, el arte y la cultura de la India (más aún cuando en unos pocos años va a convertirse en la nación más poblada de nuestro planeta). Y por su extensión geográfica, también es una lástima no ofrecer a nuestros estudiantes la posibilidad de introducirse en la riqueza y variedad cultural de Melanesia, Micronesia y Polinesia. El listado de regiones que deberíamos conocer algo mejor es ciertamente largo. Pues bien, sin lugar a dudas, un lugar imprescindible para componer el mosaico cultural global es Indonesia y, más en concreto, la isla de Bali. 
El catálogo que aquí presentamos responde a la muestra que, con el título Descubriendo Bali: Arte y exotismo en la crónica hispánica, se inauguró el 25 de septiembre de 2019, en la sala de exposiciones de la Biblioteca de Humanidades "María Moliner". La celebración de esta exposición durante varios meses de 2019 ha sido una excelente ocasión para corregir este olvido y ofrecer la oportunidad de adentrarse en un territorio fascinante. Enmarcada dentro de Exlibris: ciclo de actividades sobre libros y documentos de la Universidad de Zaragoza, una de sus funciones ha sido también visibilizar el rico y desconocido patrimonio bibliográfico de la Biblioteca Universitaria sobre las lenguas y culturas del sudeste asiático, y en especial, mediante obras procedentes de la Biblioteca del espía, cuya colección de Oriente supera las trecientas obras y que está depositada en la Biblioteca María Moliner de la Facultad de Filosofía y Letras. ${ }^{1}$

La comisaria de la exposición, la Dra. Marisa Peiró, buena conocedora de Bali, su cultura y todos los viajeros que se han dejado seducir por la isla, ha combinado un discurso científico sólido con una exhibición amena de libros y objetos artísticos balineses, que se completan paneles con textos muy documentados y, también, con algunas películas que proyectaron una exótica imagen de Bali que todavía hoy persiste. La exposición, dirigida a nuestra comunidad universitaria pero abierta al público general, se ha enriquecido con otras actividades, como un ciclo de conferencias sobre la sociedad, la cultura, la religión, el arte, la literatura, el cine, la música y el teatro o una serie de amenas y didácticas visitadas guiadas

Ciertamente, la exposición "Descubriendo Bali" hace gala de su título y con un enfoque didáctico y bien articulado nos ha permitido viajar a Bali sin salir de la Biblioteca María Moliner. No nos queda más que agradecer a Marisa Peiró su empeño en sacar adelante esta exposición y localizar, catalogar y comentar todas las piezas que componen esta exposición, en la cual se adelantan futuras líneas de investigación de gran interés, como el estudio de los

${ }^{1}$ Si bien durante mucho tiempo se desconocía la procedencia del mismo - de más de ochocientas obras referidas a ciento cincuenta lenguas, con ejemplares de hasta doscientos años- adquirido por el profesor Guillermo Redondo Veintemillas para la BUZ, este se acabó ganando el sobrenombre de Colección del Espía, y como tal fue ya objeto de catalogación y exposición de la mano de Luisa Orera y de Matilde e Inmaculada Cantín. Finalmente, se supo que este perteneció a Faustino Antonio Camazón, criptógrafo y espía, que ayudó a desentrañar la máquina Enigma y murió
parte asiática supera las trescientas obras, muy pocas de ellas hacen referencia al sudeste asiático. viajeros españoles, y en especial los aragoneses, que a lo largo del tiempo han visitado Bali y han escrito sus crónicas y libros de viaje.

La realización de la exposición ha sido posible gracias a la colaboración del Vicerrectorado de Cultura y Proyección Social de la Universidad de Zaragoza, la Biblioteca de la Universidad de Zaragoza y la Facultad de Filosofía y Letras. Queremos agradecer el trabajo exhaustivo realizado por Marisa Peiró y el apoyo, así como la generosidad de los coleccionistas privados que han prestado obras para la exposición; además, de, por supuesto, la colaboración de la Biblioteca General -que prestó algunos de sus centenarios volúmenes- $\mathrm{y}$ a todo el personal de la Biblioteca y universitario que han hecho posible esta pequeña, pero ambiciosa, actividad.

Zaragoza, noviembre de 2019.

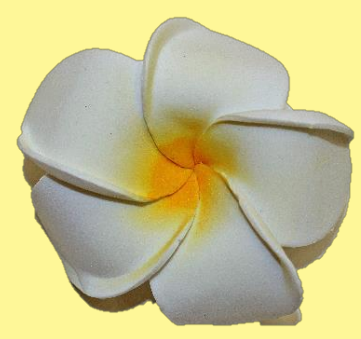




\section{Presentación}

"Hoy, casi todo el mundo ha oído hablar de Bali. Para algunos significa un pequeño sitio al que ir, uno de tantos puertos de un crucero alrededor del mundo; a otros, les evoca imágenes de chicas morenas con pechos bonitos, palmeras, olas, y todas aquellas nociones románticas que la convierten en un paraíso de los Mares del Sur. En general, la idea popular sobre Bali acaba aquí.” - Miguel Covarrubias, 1937.

Con estas palabras, el artista y antropólogo mexicano Miguel Covarrubias daba comienzo a su libro Island of Bali (1937), el más importante escrito sobre esta isla hasta la fecha. A pesar de su cronología, estas líneas siguen de gran actualidad, pues la indonesia isla de Bali se ha reafirmado como uno de los destinos turísticos más importantes del mundo. Pero esto no siempre fue así. Aunque la presencia hispánica en la actual Indonesia se remonta a principios del s. XVI, cuando diferentes potencias se disputaron las islas Molucas y sus valiosas especias, Bali pasó desapercibida (incluso para los británicos y holandeses que finalmente ocuparon la región) hasta principios de siglo XX, momento en el que, mediante libros, canciones y películas, comenzó a forjarse una peculiar imagen que sigue, en cierto modo, vigente.

La exposición Descubriendo Bali: Arte y exotismo en la crónica hispánica proponía realizar un viaje hacia la cultura balinesa, e instaba a hacerlo de la misma manera en la que muchos se enteraron de su existencia: a través de libros, revistas, imágenes llamativas, películas, y materiales artísticos y artesanales que nos hablan no solo del arte y la historia de Bali, sino también del impacto y la impresión que estos causaron en sus visitantes, tratado de recrear la sugerente atmósfera que atrajo a artistas, escritores y viajeros durante las primeras décadas del siglo XX. La exposición, resultado de una investigación doctoral, recopiló, por vez primera, los relatos y descripciones de toda una serie de visitantes españoles e hispanoamericanos, entre los que destacan personajes como el físico aragonés Julio Palacios, el historiador de alta alcurnia Ricardo Martorell y Téllez-Girón -cuyo texto se reedita, mediante este catálogo, por primera vez-, los poetas Gerardo Diego y Pablo Neruda, o el artista y antropólogo Miguel Covarrubias. La muestra, y también este catálogo, proponía ilustrar el

2Para la exposición se seleccionaron obras en lengua sánscrita, malaya, javanesa e indonesia, similares a los que estudiosos y viajeros utilizaron para sus pesquisas. contenido de los libros mediante la combinación de diferentes materiales didácticos, aunando bibliografía e infografías, con vídeos y piezas artísticas y artesanales (pinturas, tallas, textiles, marionetas...), a través de obras que pertenecen tanto al rico patrimonio de la Universidad de Zaragoza (en especial, de la llamada "Colección del Espía")2 como a diversas colecciones privadas.

La muestra estuvo estructurada en diferentes vitrinas y secciones que permitían adentrarnos en aspectos esenciales de la vida cotidiana en Bali, así como en los diferentes tipos de ensayos, películas y relatos, que ayudaron a construir esa imagen del Otro que todavía se tiene sobre Bali. Confiamos en que, a partir de los diversos contenidos, esta fascinación por Bali que sacudió y sobrecogió al mundo entero durante buena parte del s. XX, no caiga en el olvido y que esto permita estrechar los lazos entre la Universidad de Zaragoza y esta remota, pero importante, parte del mundo.

Marisa Peiró Márquez

Zaragoza, noviembre de 2019. 


\section{EL DESCUBRIMIENTO DE BALI POR OCCIDENTE}

"Bali es la hermana menor de la riquísima Java. Todo parece vivir en aquella isla paradisiaca con la fragancia de la pubescencia. (...) Los balineses -malayos de razaconservan su civilización de abolengo hindú, con una ejecutoria limpia de injerencias o invasiones extrañas. (...) Acaso también, por la misma razón, los balineses son, entre todos los pueblos malayos, los más perfectos, vivir su vida.” - Ricardo Martorell (1933)

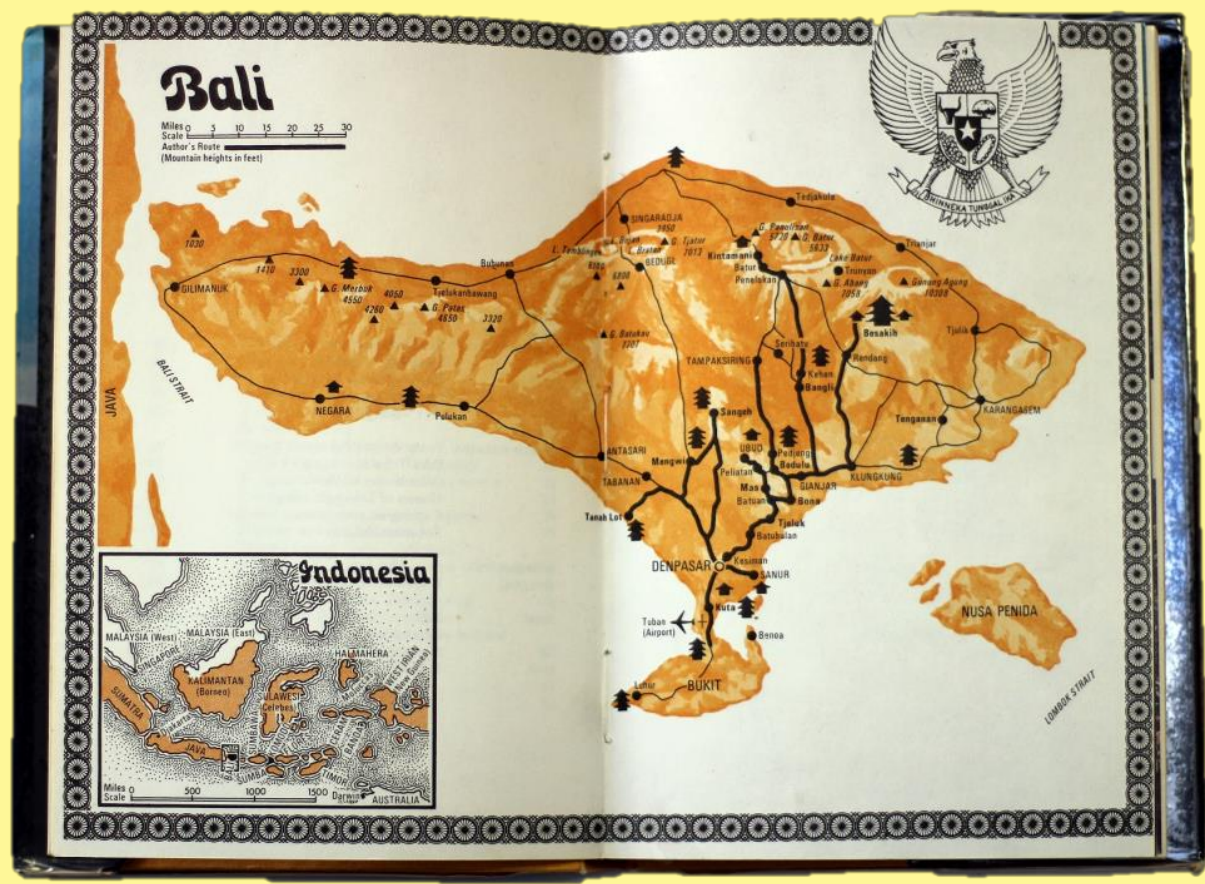

Libro Bali and beyond (Simpson, Colin, Londres, Angus and Robertson, 1973). Colección particular.
Con sus casi cuatro millones de habitantes, Bali nunca ha sido una isla perdida o insignificante. De clima benigno pero susceptible a desastres naturales (como la erupción de los volcanes que surcan y rodean la isla, o los tifones y tormentas que constantemente la amenazan), su economía se basó durante milenios en el cultivo y venta del arroz, hasta que a principios del siglo XX alguien se dio cuenta de su excepcionalidad y comenzó a publicitarse como uno de los últimos paraísos terrenales. Hoy recibe más de tres millones de turistas al año.

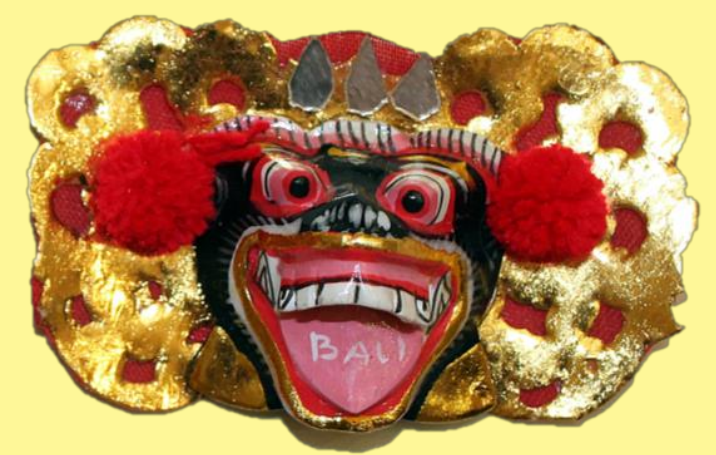

Máscara decorativa con motivos de Barong, de carácter turístico. Técnica mixta. S. XXI. Colección particular.

Pero la historia de Bali es mucho más antigua que su descubrimiento comercial. Situada geográficamente junto a la línea de Wallace, el límite físico y geográfico entre Asia y Oceanía, la isla fue habitada desde la prehistoria. 
Muchos rasgos culturales de este periodo perviven aún en usos y costumbres, además de en piezas artísticas como las tjilís ${ }^{3}$ o en la Luna de Pejeng (el mayor timbal del bronce del mundo) y en bailes y ritos de la religión popular. Aunque poco se sabe sobre su primitiva organización, se cree que en este periodo el arroz, y lo necesario para cultivarlo (el agua y su reparto y canalización) ya era considerado el elemento económico principal, y, por tanto, regía la administración y religión de los balineses, aunque también se comerciaba con culturas vecinas como son los Dong Son del actual Vietnam.

Durante los primeros siglos de nuestra era, la religión hinduista (mezclada con una fuerte dosis de budismo) se expandió por diferentes territorios del sudeste asiático; Bali no escaparía a esta ola, aunque durante el primer milenio parece haber sido cultural y económicamente dependiente de varios reinos indobudistas más importantes de Malasia, Sumatra, y, especialmente, Java y Madura, con las que compartía un pasado. La invisible línea de Wallace hacía, a su vez, de frontera natural entre estos reinos y las islas de la Oceanía indonesia, como Timor o Alor, adónde no llegó la nueva cultura venida del continente. También fue en este momento cuando llegaron a Bali mercaderes del sur de China y de lugares tan lejanos como la Península Arábiga, que dejaron en la isla una importante impronta cultural.

Durante los ss. X y XI Bali comenzó a adquirir cierta autonomía de Java (dependía entonces del reino de Medang). Este momento coincide con el gobierno del casi legendario rey Erlangga, nacido en la nobleza balinesa y que consiguió crear un nuevo reino en la isla vecina. Es entonces cuando comienzan a forjarse algunas de las tradiciones culturales más importantes, como la pintura, el teatro, o las convenciones en el vestir, reforzadas durante el posterior gobierno de la dinastía Mahapajit (1293-1527), imperio talasocrático con más

${ }^{3}$ Se conoce como tal una representación esquemática, realizada en materiales perecederos diversos, pero entre los que sobresale la hoja de lontar, de Dewi Sri, diosa del arroz, la fertilidad y la riqueza venerada desde tiempos inmemoriales pero que adoptó su nombre actual con la llegada del hinduismo. También son muy populares las representaciones de la pero que adoto su no la diosa realizadas con monedas, tipología que data de fina es del pron a Bali prosperidad y el dinero. Estos (sobre todo, los chinos) trajeron consigo un tipo de moneda que hoy se conoce en Bali como monedas y quedaron ligadas a un uso ritual, asociándose a la riqueza y a la buena suerte, y utilizándose en ceremonias de noventa reinos tributarios que logró unir bajo una sola corona a territorios de las actuales Indonesia, Malasia, Singapur, Filipinas y Brunei, entre otros lugares. Tras un largo, pero intenso proceso de expansión, el islam llegó a

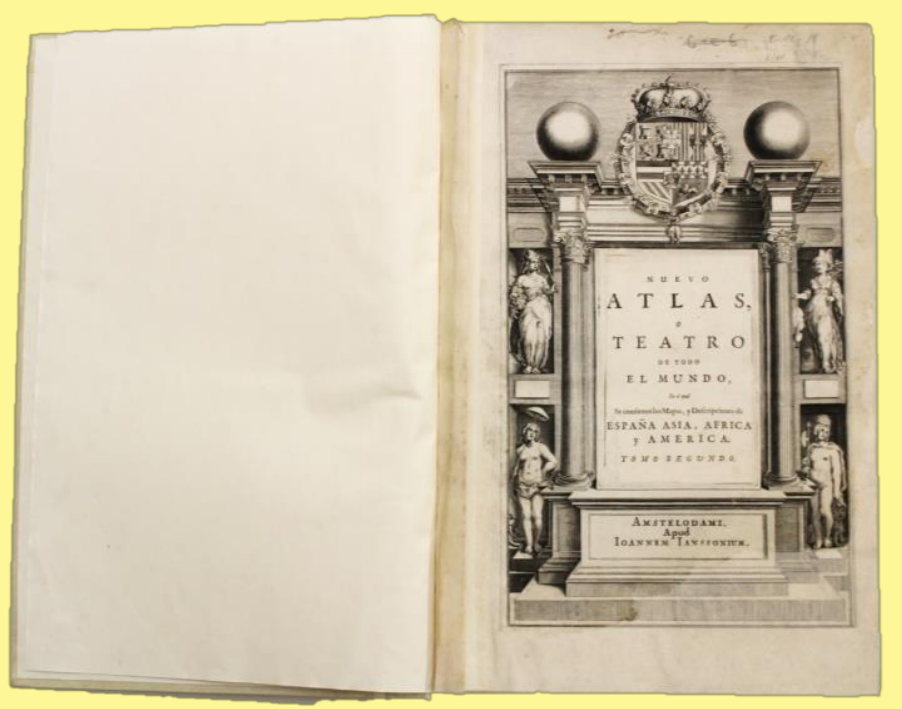

Libro Nuevo Atlas o teatro de todo el mundo, en el qual se contienen los mapas, y descripciones de España, Asia, Africa y America, tomo segundo. (Janssonius, Johannes, Amsterdam, Apud Ioanemm Ianssonium, 1653). Colección de la Biblioteca de la Universidad de Zaragoza.

relevantes. Por, más pronto que tarde, comenzaron a utilizarse también para realizar figuras de Batara Sedana y Dewi Sri respectivamente, dios de la Riqueza y diosa de la Agricultura y la Fertilidad-, a las que se agregaban cara y manos de manera. Las llamativas figuras fueron descritas por los visitantes extranjeros como muñecas, pero no debe olvidarse su carácter propiciatorio; era habín 
las islas indonesias durante el s. XV, asentándose definitivamente tras la caída de los Mahapajit a manos del sultanato de Demak y de la conquista portuguesa de Malacca a principios del s. XVI. Este periodo es de vital importancia porque las cortes hinduistas javanesas se refugiaron en Bali, dando un nuevo impulso a las artes y fomentando el aislamiento, cultural y económico de la isla, todavía hoy el último reducto hinduista en la región.

Aunque algunos viajeros europeos tenían noticia de la existencia de Bali desde, al menos, finales de la Edad Media, no fue hasta 1512 que arribó a tierras balinesas la primera expedición occidental, liderada por los portugueses Antonio Abreu y Francisco Serrão. Rodeada de ricas y codiciadas islas como Sumatra, Borneo o Java, Bali ni siquiera figuraba ni en la mayoría de crónicas ni mapas (o lo hacía bajo el nombre de "Boly", "Bale", "Bally" o "Balí"), ya que era apenas una curiosidad "salvaje" en la ruta hacia las islas Molucas, verdadera joya de la corona gracias a sus valiosas especias (clavo, pimienta, canela y nuez moscada). 4

Libro Nuevo Atlas o teatro de todo el mundo, en el qual se contienen los mapas, y descripciones de España, Asia, Africa y America, tomo segundo. (Janssonius, Johannes, Amsterdam, Apud Ioanemm Ianssonium, 1653). Colección de la Biblioteca de la Amsterdam, Apud Ioane

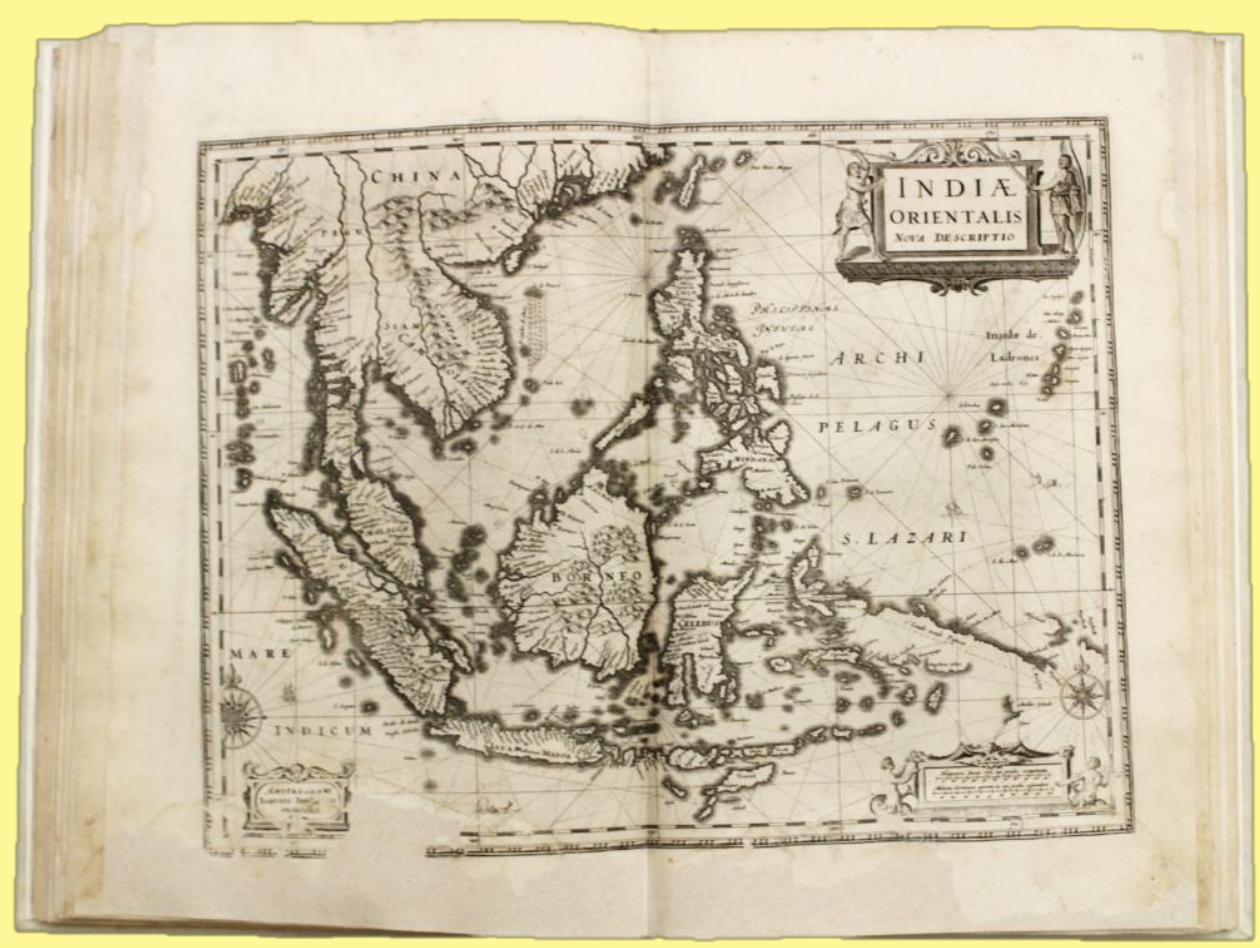

4 "Descubiertas" por los portugueses en 1512 en la misma expedición de Serrão, las Molucas fueron uno de los principales asuntos de disputa entre los reinos españoles y Portugal a principios del siglo XIV. Si bien el Tratado de Tordesillas (1494) reguló la distribución de las nuevas tierras encontradas allende el Océano Atlántico y el control de las plazas comerciales africanas, la llegada de los portugueses a Asia (Goa, Ormuz, Malaca y otros tantos puertos) provocó otro tipo de problemas. Cuando la nave de Serrão encalló en las tierras del sultán de Ternate, este vio la oportunidad de establecer una alianza con los portugueses que le protegiese de las naciones vecinas, y más adelante, en 1522, permitió la fundación de un primer fuerte portugués (hoy conocido como Kastela). Este mismo año, la expedición de circunvalación del globo encabezada por Fernando de Magallanes (que tenía como objetivo alcanzar las Molucas desde Occidente, lo que permitiría reclamarlas como castellanas) llegó al fin a su objetivo. Poco después, la expedición comandada por Juan Sebastián Elcano y García como castellanas) llegó al fin a su objetivo. Poco después, la expedición comandada por Juan Sebastián Elcano y García Jofré de Loaisa (el nuevo Capitán General y Gobernador de las Molucas), arribó al vecino -y enemigo- Sultanato de Tidore, donde fundarían un importante fuerte. Esto generaría otro conflicto militar con los portugueses, que pronto derrotarían a los castellanos en Tidore. Las disputas se dirimirían, oficialmente, con la firma del Tratado de Zaragoza entre las delimitaría las zonas de influencia castellana y portuguesa en Oriente. En realidad, Portugal compró los derechos sobre las Molucas por 350.000 ducados de oro, pero el tratado incluía una cláusula por la cual este podía anularse si se devolvía el pago. Más adelante, Castilla centraría sus esfuerzos en establecer una nueva ruta comercial que atravesase el globo sin depender del mercado portugués, algo que finalmente sucedió cuando Andrés de Urdaneta descubrió la ruta de Tornaviaje, se estableció la ruta del Galeón de Manila (que paraba en el Virreinato de Nueva España y dejaba ahí parte de la riqueza) y las Filipinas se convirtieron en el nuevo centro de la riqueza) ylas Filipinas se convirtieron en el nuevo centro del comercio en Asia. A principios del siglo XVII comenzó la colonización (militar y economica) holandesa en la región perdiendo progresivamente las monarquías hispánicas su peso La Compañía Neerlandesa de las Indias Orientales llegó a las 
Durante este periodo, y hasta después de época napoleónica (cuando los británicos comenzaron a tener interés en la región), Bali está prácticamente ausente de mapas y crónicas, y cuanto aparece, lo hace en registros sumamente inexactos, a menudo fueron escritos por personajes que jamás visitaron la región.

Entre los siglos XVI y XIX, Bali no despertó demasiado interés entre los colonizadores holandeses, británicos y portugueses que se disputaban las islas vecinas por sus ricas especias y recursos naturales, a pesar de lo cual, se establecieron algunos contactos. En 1597, el explorador Cornelis de Houtman (responsable del establecimiento de buena parte de las rutas comerciales holandesas en la región) llegó a Bali, visitó varios de sus reinos -dejando interesantes crónicas- y consiguió comerciar con pimienta negra; en 1601, una expedición encabezada por Jacob van Heemskerck consiguió causar buena impresión en la corte del rajá de Gelgel, pero poco más se logró. A pesar de los variados contactos, portugueses y holandeses fracasaron en el intento de formalizar el comercio con Bali y solo ocasionalmente realizaron misiones comerciales. Su principal mercancía (que a veces obtenían mediante intermediarios chinos, árabes y bugineses) fueron las esclavas balinesas, que de buen grado eran vendidas por los diferentes rajás de la isla, a cambio de opio, en el puerto de Buleleng. Codiciadas por su belleza y capacidad artística (con los hombres se comerció mucho menos), la mayoría eran huérfanas o viudas y pertenecían a familias de deudores, criminales o, sencillamente, opositores a los diferentes gobernantes.

Pero el panorama cambión con el declive de la Compañía neerlandesa de las Indias Orientales y las nuevas inquietudes coloniales de Francia y Reino Unido en el siglo XIX, los Países Bajos se decidieron a hacer una conquista efectiva (militar, y no solo económica) de todos aquellos territorios que sobre el papel les pertenecían.

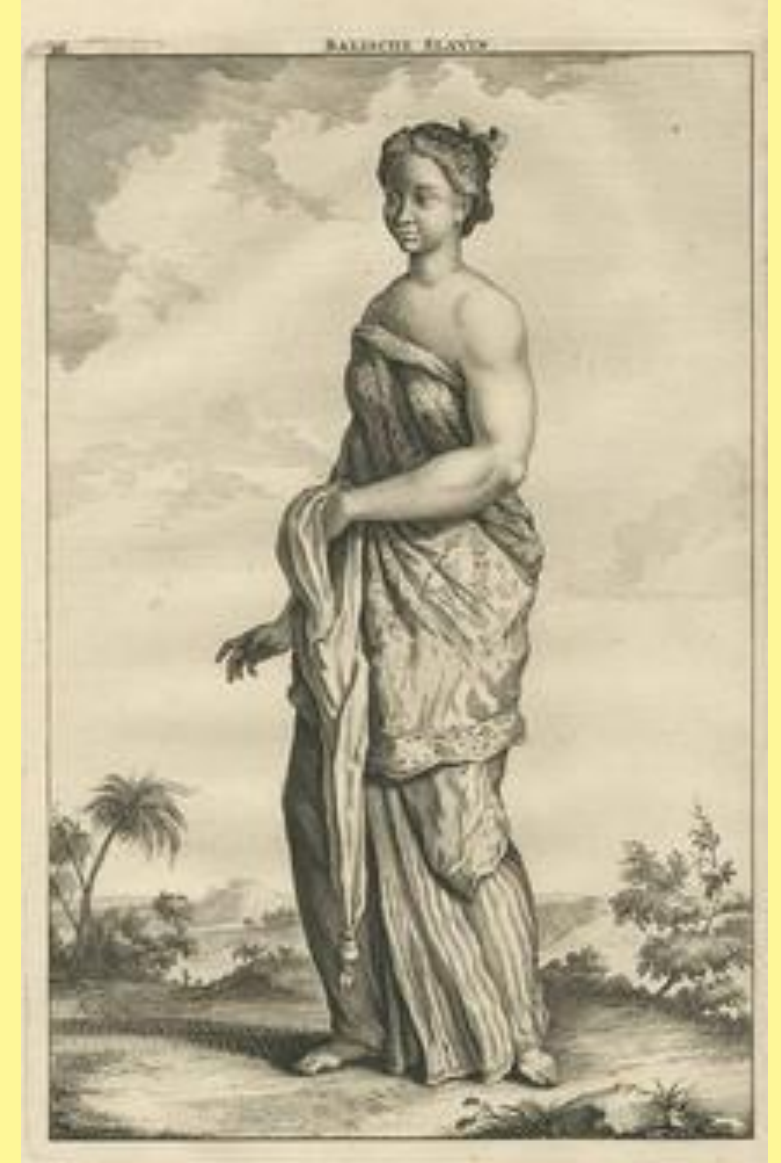

Esclava balinesa, por C. de Bruyn (c.1711)

Molucas en 1599 de forma sumamente violenta y rápidamente se hicieron con el control de muchas de sus islas; tanto es así, que, incluso en 1655, los habitantes de Kelan capturaron al Príncipe de Ternate (que había sido el principal fuerte portugués) para apaciguar a los violentos holandeses. Los castellanos abandonarían Tidore, su última posesión en las Molucas, en 1663, y durante mucho tiempo únicamente los británicos consiguieron disputarse el control de la región. 
Tras la cruenta conquista, los holandeses no tardaron en darse cuenta de qué no había merecido la pena: Bali ofrecía escasa rentabilidad como fuente de materias primas o de mano de obra. No obstante, el que hubiera permanecido al margen de los cambios culturales y económicos del colonialismo le otorgaba un aspecto distintivo, con un envidiable y fotogénico entorno natural y una distinta y distante cultura; por ese motivo, en un momento en que los famosos Mares del Sur eran el tema de moda en la literatura, el arte y el cine, decidió promocionarse la isla como una suerte de paraíso perdido y museo viviente que les hiciera competencia, convirtiéndose en uno de los primeros destinos de turismo natural y cultural del mundo.

Así, a partir de 1909 se construyeron las primeras carreteras y se habilitaron, por primera vez, barcos regulares que conectasen la isla con Java. Sería la Compañía Postal holandesa, la K.P.M., quien gestionaría estas primeras rutas turísticas. En Denpasar, la nueva capital, se abrió la primera casa de huéspedes, que luego se convertiría en el Bali Hotel (al principio apenas un edificio colonial con camas de hospital, muy alejado de los lujosos hoteles de otras ciudades asiáticas), y unos pocos inversores compraron los primeros coches que permitirían realizar a los turistas más aventureros "cómodos" viajes de varios días por la isla, en los que visitaban los arrozales y alguno de los más de veinte mil templos que todavía pueblan su territorio.

Entre 1909 y 1942 -momento en el que los japoneses invadieron la isla-, los holandeses intentaron escolarizar a la población, mejorar las comunicaciones e incentivar la economía, pero también impusieron polémicas medidas en la religión y la vestimenta (como la obligación de llevar camisa, que causó otra oleada de suicidios). Paradójicamente, sería el contacto con artistas y antropólogos extranjeros que comenzaron a llegar durante ese periodo lo que permitió no solo que muchas tradiciones se registraran -y que, gracias a ellos, todavía nos sean conocidas-, sino que esto también incentivo el auge de las industrias culturales locales en la que ya nunca habría vuelta atrás, y que impulsó a Bali hacia una nueva era en la que todavía nos encontramos.

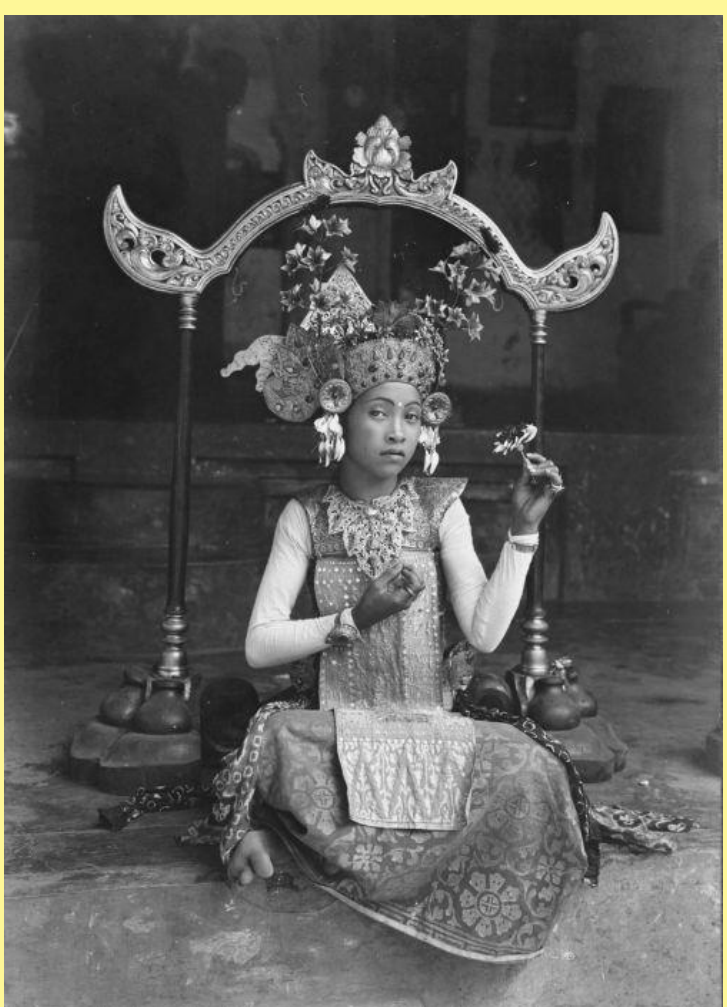

Fotografia de Thilly Weissenborn, pionera de la fotografia en las Indias Orientales. 


\section{BALI ANTE EL MUNDO Y EL MUNDO EN BALI}

"Sin duda, muy pronto Bali estará "echada a perder" para aquellos viajeros quisquillosos que detestan todo lo que traen consigo." - Miguel Covarrubias, 1937.

La mejor campaña publicitaria que Bali pudo tener no provino de una iniciativa oficial, sino de los singulares, exóticos y sumamente atractivos comentarios e imágenes que sobre la isla publicaban sus cada vez más interesantes visitantes. El primer artista relevante en Bali sería el errático W. O. J. Nieuwenkamp (1874-1960), periodista y artista gráfico holandés, que visitó la isla en varias ocasiones y que se dedicó mediante una serie de libros ilustrados, como Bali en Lombok (1906), ${ }^{5}$ a difundir las bondades y beldades de la isla entre sus congéneres de la metrópoli. A pesar de que el autor visitó Bali en 1906 (y que asistió a la conquista y destrucción de Denpasar), su libro hablaba de la isla en una atractiva clave art nouveau al tiempo que se interesaba por las formas de representación autóctonas.

El libro que provocaría el gran flechazo entre Bali y Occidente no sería ilustrado sino fotográfico, y llegaría unos años más tarde de la mano del entregado doctor alemán Gregor Krause (1883-1959), que llegó a Bali en 1912, destinado a la aldea de Bangli como médico de la administración colonial. A pesar de que Krause no encontró un Bali lujoso ni monumental, fue capaz de hallar la belleza en la fragilidad de sus aldeas y gentes que, hambrientas y débiles tras las guerras coloniales, luchaban por transmitir y embellecer sus tradiciones. Hubo que esperar a 1922 para que Bali $1912,{ }^{6}$ con texto de Krause y más de cuatrocientas fotos que tomó durante el ejercicio de su profesión, fuese publicado, y para que tanto la isla como el autor alcanzaran la fama. Krause aportó a la imagen de la isla uno de sus elementos más atractivos y persistentes, del que todavía no se ha librado: bellas mujeres semidesnudas. Sus retratos de pobreza rural y religiosidad tradicional fueron entendidos, especialmente en los Estados Unidos (su libro se tradujo al inglés en 1926, con gran éxito), como un ejemplo de libertad y de exuberancia femenina. Para aquel entonces, y aunque a la gente todavía le

5 Nieuwenkamp, W.O.J. Bali En Lombok: zijnde verzameling geïllustreerde reisherinneringen en studies omtrent Land en Volk, Kunst en Kunstnijverheid. Amsterdam, De Zwerver, 1906. costaba situar Bali en un mapa, se sabía que era un lugar de hermosas mujeres morenas, apacible y tranquilo, algo de lo que el mundo del cine no tardaría en hacerse eco.

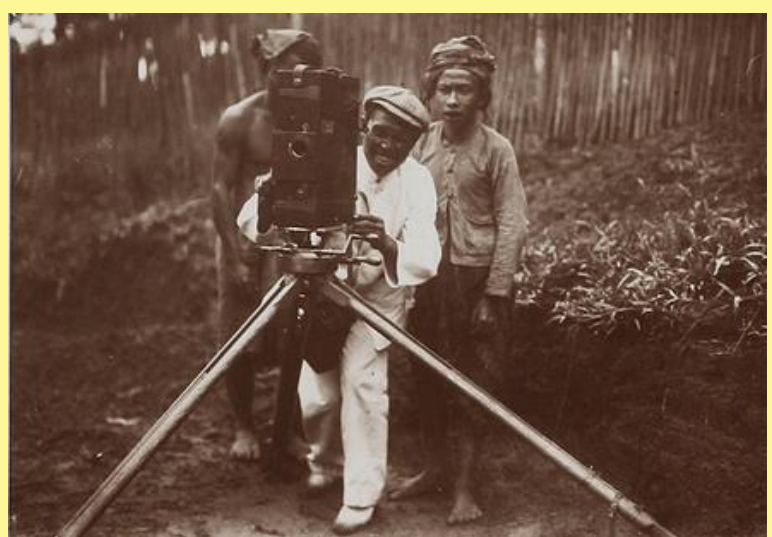

Gregor Krause fue uno de los pioneros de la difusión del Bali rural que tanto atraería a los viajeros del periodo de entreguerras.

En 1926 llegaría a Bali su visitante más ilustre, Walter Spies (1895-1942), que fue de todo menos un turista. Nacido en Moscú, se formó como músico y pintor de vanguardia en Alemania. En 1923 aceptó un puesto en la orquesta de gamelán del sultán de Yogyakarta, y tres años más tarde llegó a Bali. Pronto, y mientras se dedicaba a estudiar y a escribir sobre las artes locales (en especial la música y la

${ }^{6}$ Krause, Gregor, Bali: volk, land, tanze, feste, tempel. Munich, Georg Muller Verlag, 1926 
danza), Spies se autoproclamó embajador de los extranjeros en Bali, ofreciéndose como guía y anfitrión de todo recién llegado. En poco tiempo Spies logró ser el más experto conocedor de la isla, y requerido y amado por todos. A partir de 1938, se haría construir un "refugio" de montaña en el que se alojarían, entre otras celebridades, Charles Chaplin, Noël Coward, Vicky Baum (quien, ayudada por Spies, publicó su famosa novela Amor y muerte en Bali) o Colin McPhee. Por ello, no es extraño que cuando cineastas como Roosevelt o Denis recalaron en la costa balinesa acudieran a su búsqueda para que les ayudase a rodar películas de aventuras.
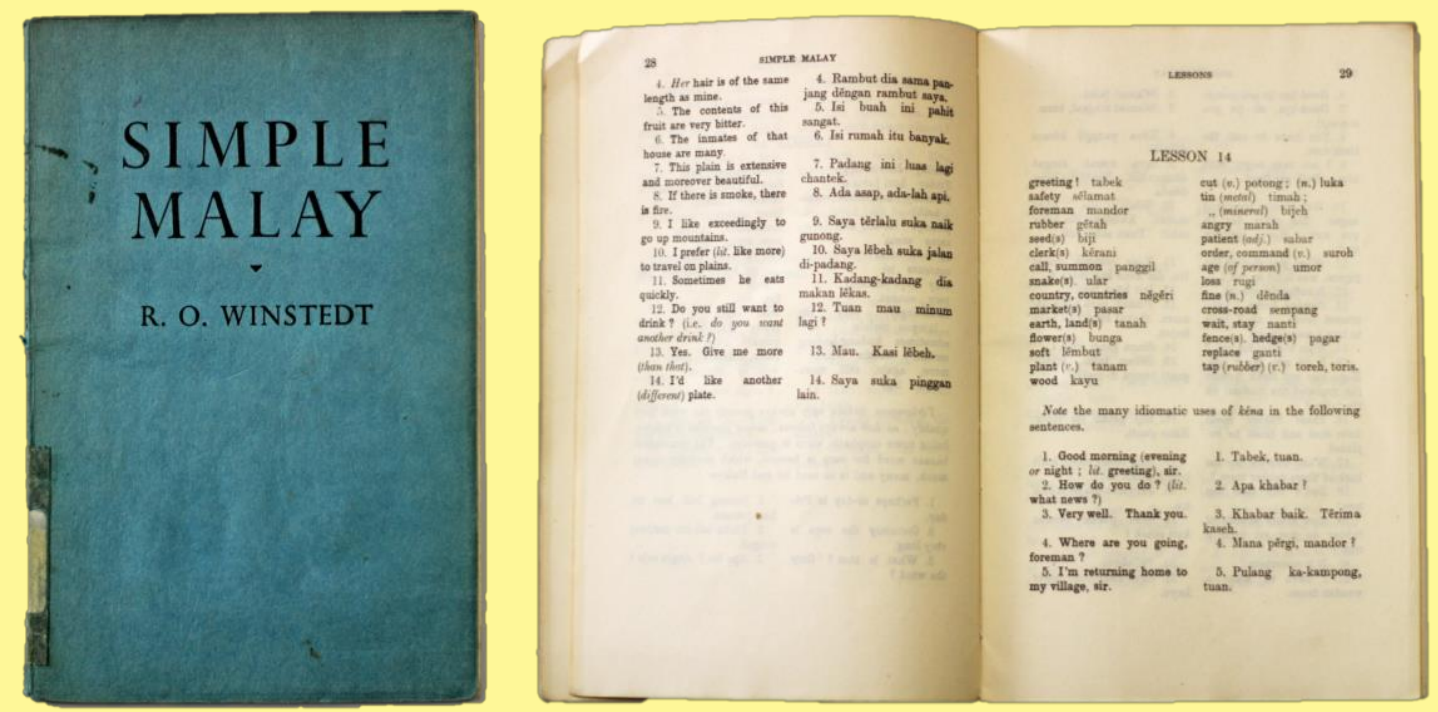

Sobre estas líneas, libro Simple Malay (Richard Olof Windstedt. Nueva York, Longsmans, 1946). Colección de la Biblioteca de la Universidad de Zaragoza. A la derecha, arriba, libro A handbook of spoken Bazaar Malay (J.J. McHugh, Singapur, Kelly \& Walsh, 1951). Colección de la Biblioteca de la Universidad de Zaragoza y, debajo, libro Spoken Bazaar Malay, Teach yourself malay (M. Blanche Lweis, Londres, The English University Press, 1949). Colección de la Biblioteca de la Universidad de Zaragoza.
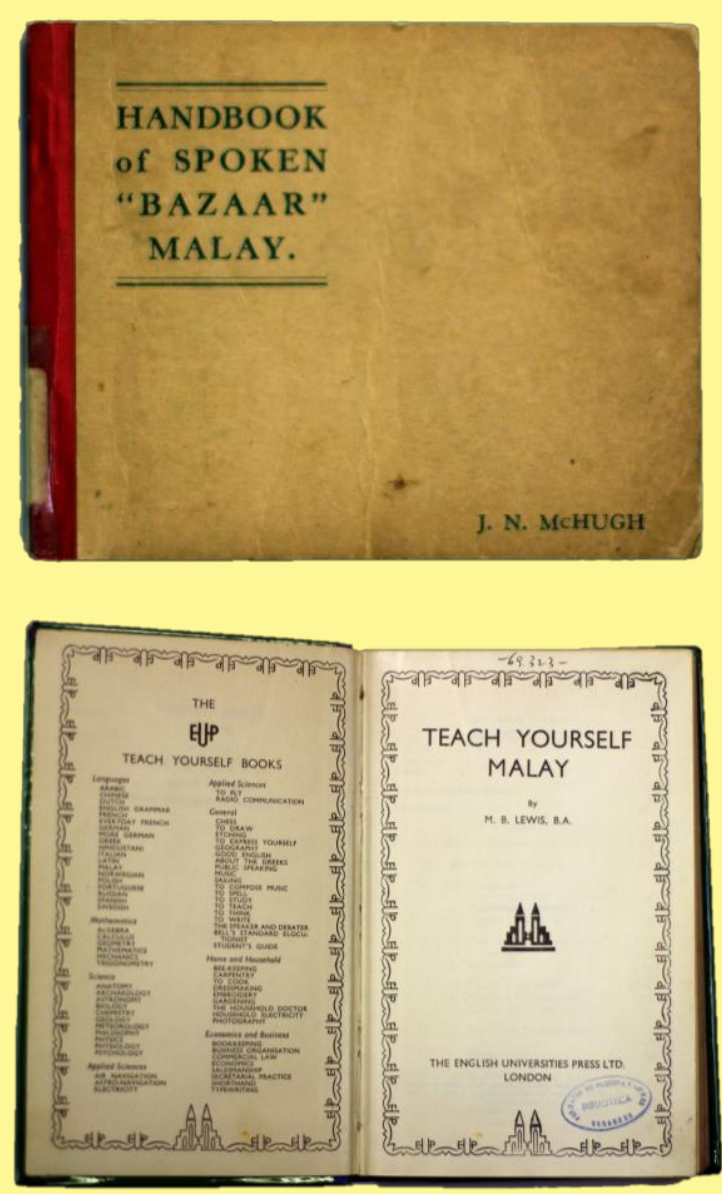

En 1930 llegó a la isla uno de sus visitantes más ilustres, el mexicano Miguel Covarrubias (1904-1957). Tras una exitosa y precoz carrera 
como ilustrador en Nueva York (donde trabajaba para grandes editoriales y revistas como Vanity Fair, Vogue o The New Yorker), Covarrubias llegó a Bali en su luna de miel -en esto sería uno de los pioneros- pero no fue un viajero corriente. No viajó a la isla en un crucero de lujo sino en un carguero, y durante el trayecto se tomó las molestias de aprender malayo (entonces lingua franca de la región), lo que le permitió a él y a su esposa, la bailarina y modelo Rosa Rolando, tener un mejor entendimiento de la cultura balinesa. La pareja, guiada por Spies, residió en la isla durante nueve meses, viviendo incluso en la casa de un noble local (pues el Bali Hotel les desagradaba), y se convirtió pronto en experta en el microcosmos balinés: Miguel tomó bocetos y pintó algunos gouaches, y Rosa se interesó por la gastronomía y por el baile. A su vuelta a Nueva York, en 1932, Miguel realizaría una exitosa exposición de pinturas que despertó el interés de la alta cultura por la isla.

Tras Covarrubias, llegarían a Bali la mayoría de turistas y celebridades: las cifras se triplicaban año a año, y comenzaron a construirse los primeros hoteles de lujo, que a menudo contaban con su propia compañía de música y bailes tradicionales. Bali se fue definiendo como un lugar de lujo y voluptuosidad, además de un oasis de libertad religiosa y sexual. En 1937, y fruto de un segundo viaje de investigación a la isla, Miguel Covarrubias publicaría su gran best seller, Island of Bali, que agotó una segunda edición antes de salir a la venta y que estuvo acompañado de campañas de ilustraciones y diseños de telas en revistas y grandes almacenes. La diferencia con otros libros precedentes es que los Covarrubias habían pasado un año en la isla documentándose: Miguel tomaba notas, dibujaba y leía, mientras que Rosa entrevistaba a los locales y tomaba fotografías.

El final de la década de los 30 constituyó una época dorada para Bali. Impulsado en un primer lugar por el mundo frívolo, venía ahora respaldado por artistas e intelectuales. El libro de Covarrubias, todavía hoy de referencia sobre la isla, marcaba al paso de la adoración primitivista al genuino interés antropológico por la cultura balinesa, que vio la llegada de una serie de antropólogos, artistas y estudiosos. Tanto es así, que en 1936 Geoffrey Gorer llegó a decir sobre Bali que "en los últimos diez años, de esta isla se ha escrito, ha sido filmada, fotografiada y comentada efusivamente hasta un extremo que rusticaría la náusea".

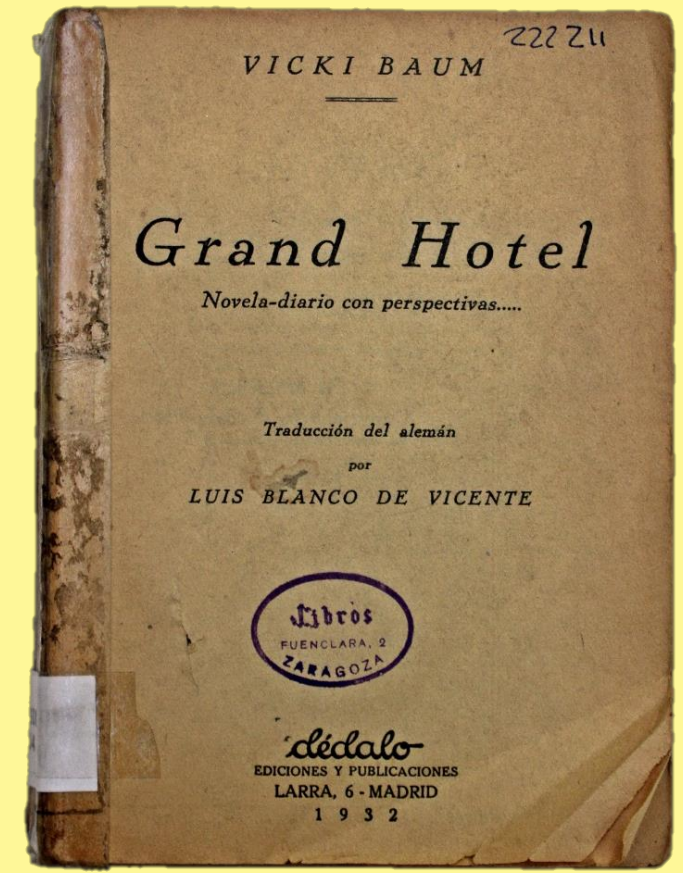

Libro Grand Hotel: novela-diario con perspectivas (Baum, Vicki, Madrid, Dédalo, 1932), Colección de la Biblioteca de la Universidad de Zaragoza.

En el campo de las artes plásticas, la isla se fue convirtiendo en un reducto para pintores occidentales: además de Spies y Covarrubias, se asentaron muchos otros, como el holandés Rudolf Bonnet (1895-1978), el belga AdrianJean Le Mayeur (1880-1958), el filipino Antonio Blanco (1912-1999) o el chino Lee Ma 
Fong (1913-1988); al campo de la música y la danza llegaron profesionales y estudiosos como Beryl de Zoete (1879-1962), Colin McPhee (1900-1964) -que escribió el primer estudió occidental sobre gamelán- o el propio Spies. La danza fue el tema predilecto de Margaret Mead (1901-1978) y Gregory Bateson (1904-1980), los más importantes antropólogos que estudiaron y residieron en la isla, de la que serían considerados los mayores expertos hasta la llegada de Clifford Geertz (1926-2006), Adrian Vickers (1958) o Bruce W. Carpenter.
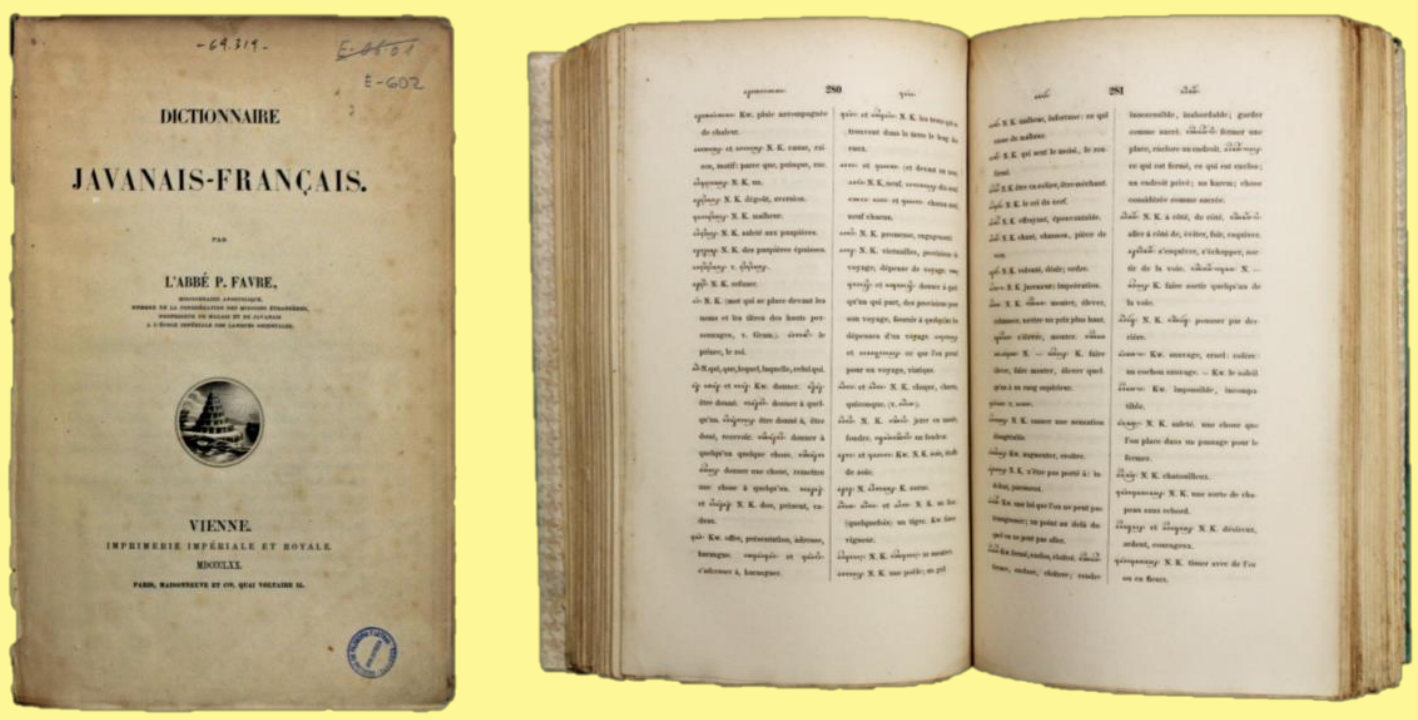

Dictionnaire javanais-français (Favre, Pierre Étienne Lazare, Viena, Imprimerie Impériale et Royale, 1870). Colección de la Biblioteca de la Universidad de Zaragoza.

Si bien la irrupción de Bali en la cultura de masas y en el imaginario popular fue particularmente tardía, esta alcanzó un desarrollo sin parangón. Muchos de los primeros libros sobre la isla no dudaban en llamarla "isla de los dioses", "isla de los demonios" o, incluso "isla de los pechos desnudos", al mismo tiempo que el epíteto de "último paraíso" y "paraíso perdido" se iba haciendo una constante en los textos sobre Bali. Buena parte de la culpa se debió al mundo del cine, que tuvo con la isla una relación particularmente curiosa. Al margen del ámbito gubernamental, los primeros cineastas que llegaron a Bali, André Roosevelt (1879-1962) y Armand Denis (18961971), acudieron a Walter Spies en busca de asesoramiento para realizar su gran película. Aunque Roosevelt había llegado a la isla en 1924, no fue hasta 1928 cuando comenzaron a rodar la que fuera la película más importante sobre Bali: Goona-Goona (también conocida como The Kriss y Black Magic). Con una trama convencional que combinaba romance, esoterismo y aventuras selváticas con algo de desnudez se convirtió en un gran éxito tras su estreno en 1930. Tras ella, se produjo toda una serie de películas catalogadas como "épica Goona-Goona", que, a pesar de su bajo presupuesto y escasa coherencia, llegaron a tener gran éxito: destacan la alemana Insel der Damonen (1933), o las americanas Virgins of Bali (1932), Legong (1935) y Wajan, son of a witch (1937). Aunque la mayoría de estos filmes de explotation poco o nada tenían que ver con Bali (ialgunos incluso estaban ambientados en África!) y reutilizaban escenas de otras películas o de archivo, siempre mostraban mujeres de armas tomar, desvestidas para la ocasión. Su éxito se explica ya que conseguían burlar la censura del Código Hays, que prohibía prácticamente cualquier 
atisbo de sexualidad en pantalla; amparados en las diferencias culturales (incluso llegaron a presentarse como "desnudez para todos los públicos") estos filmes colmaron las expectativas de sensualidad en las pantallas, gozando, por ello, de un gran éxito y rentabilidad.

Gracias a libros como Bali: last Paradise (1930), de Hickmann Powell, Bali, enchanted island (1935), de Helen Eva Yates, o las obras de Nieuwenkamp, Krause y Covarrubias, para finales de la década de los 30, Bali no solo inundaba las salas de cine, sino que hacía lo propio con las estanterías y escaparates de muchos comercios. Incluso, aprovechando el tirón mediático, Covarrubias llegó a ser contratado por los grandes almacenes Franklin Simon \& Co., de la Quinta Avenida de Nueva York, para diseñar una serie de escaparates y telas inspiradas en el tradicional batik balinés.

Pero mientras que, en los Estados Unidos, y, por ende, en el mundo entero, Bali se erigía como una comuna de libertad, creativa y personal, la realidad era bien distinta: en 1938 se produjo en la isla un gran "pánico moral" que llevó a las autoridades coloniales holandesas a detener a gran parte de homosexuales, considerados presuntos pederastas; entre ellos, Walter Spies y el académico Roelof Goris. La Segunda Guerra Mundial sorprendió a la isla en un momento de gran efervescencia artística, y la eclipsó por completo. Ocupada por los japoneses ocuparían en 1942 y el mercado artístico y turístico se reducirían hasta lo esencial, algo que continuaría en la posterior Guerra Civil (1945-1949). Éste sería el comienzo de una época de decadencia de la que Bali nunca se recuperaría, aunque el gobierno de Sukarno (1949-1967), con toda su atención puesta en la más poblada e industrial isla de Java, vio los últimos estertores del Bali exótico y sensual.

En el ámbito popular, la reivindicación de la isla a nivel antropológico, dio lugar a la muerte del Goona-Goona, y dejó hueco para la comedia romántica, caso de Un novio para tres novias (1939) -en inglés, Honeymoon in Bali-, o de muchas otras producciones que propiciaron imágenes difusas -y erróneas- sobre la isla. Tal es el caso del best-seller sobre los Mares del Sur de James A. Michener Sucedió en el Pacífico (1947), que después se convertiría en un exitoso musical y en una película, y en donde se hablaba de una isla de Bali H'ai (fruto de la cual, la palabra Bali apareció en multitud de productos y establecimientos tiki, ambientados en Oceanía), o de la comedia musical de Bob Hope y Bing Crosby, Camino a Bali (1952), que, aunque recreaba correctamente ciertos aspectos visuales resultaba un completo descalabro a nivel antropológico. La de Hope, Crosby y Lamour fue la última gran película sobre Bali, que con la Guerra quedó relegada de las agencias de viajes hasta la posterior generalización del turismo aéreo, momento en el que Bali volvió a aparecer en el mapa (y en las estanterías de muchas personas).

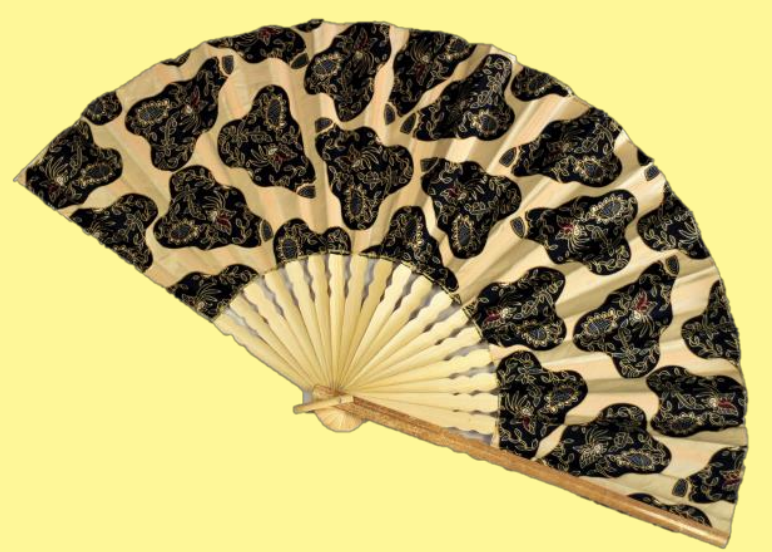

En esta página, y en las siguientes, abanicos con batik. Madera y textil. Fabricación artesanal. S. XXI. Colección particular.

La década de los 60 no fue precisamente idílica, aunque sí fue un periodo de crecimiento económico y de mejora del nivel de vida. La Guerra Fría y la intervención en Vietnam dificultaban enormemente el turismo, y el golpe 
de Estado del general Suharto y toda una serie de matanzas por motivos ideológicos hicieron que Bali prácticamente desapareciera del imaginario popular, y, por ende, de las agencias de viajes. La imagen y atractivo del Bali prístino terminó con la Segunda Guerra Mundial y no sería sino a partir de la década de los 70 -con la generalización del turismo aéreo-, y especialmente, a partir de los 90, cuando el turismo volvió con fuerza y se construyeron los resorts masivos que dispararon los precios de la isla; se potenció, más que nunca, la práctica de surf y del submarinismo, y la isla se pobló de australianos, , que ocuparon tanto playas y hoteles como las cárceles locales, dando lugar a múltiples encontronazos con las autoridades y ofreciendo una imagen completamente diferente a la que décadas atrás atrajo a escritores, artistas, antropólogos y empresarios.

Un nuevo empuje turístico y, en cierto sentido, rebrandring de Bali se produjo tras la publicación Come, reza, ama (2006), novela semibiógráfica de Elizabeth Gilbert sobre una treintañera estadounidense descontenta con su aparentemente idílica vida que decide dejarlo todo para irse, entre otras cosas, a amar a la isla de Bali (tras su purificación espiritual en la India). El libro se convertiría a su vez en un blockbuster de 2010 protagonizado por Julia Roberts. Si bien tanto el libro como la película (rodada in situ) describían un Bali correcto, aunque superficial, estos produjeron una nueva ola de veneración imbuida de espiritualidad New Age, que, para bien o para mal, volvió a situar a Bali en el mapa. Libro y película propiciaron un nuevo tipo de turismo en la isla, ligados a mujeres blancas y pudientes de mediana y tercera edad que no solo ha dejado pingues beneficios, sino que ha generado un

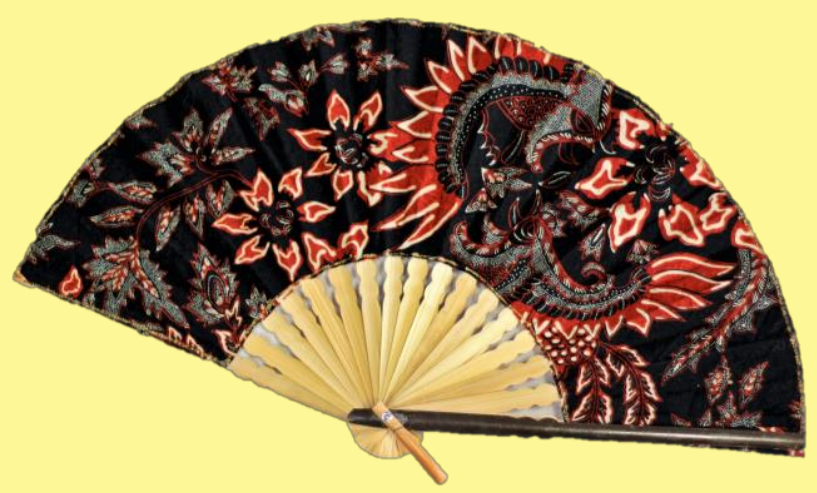
mercado de turismo sexual único en el mundo, estudiado por el premiado documental Cowboys in Paradise (2012, de Amit Virmani).

Aunque la bonanza económica se vio violentada tras los atentados islamistas del 2002 y 2004, el turismo se ha recuperado hasta el punto de resultar problemático. Las imágenes más recientes nos hablan de colosales hoteles y de una globalización que se erige casi total: el Starbucks de Ubud, ubicado en el tradicional centro religioso y artístico de la isla, recibe, hoy, muchos más visitantes que sus templos.
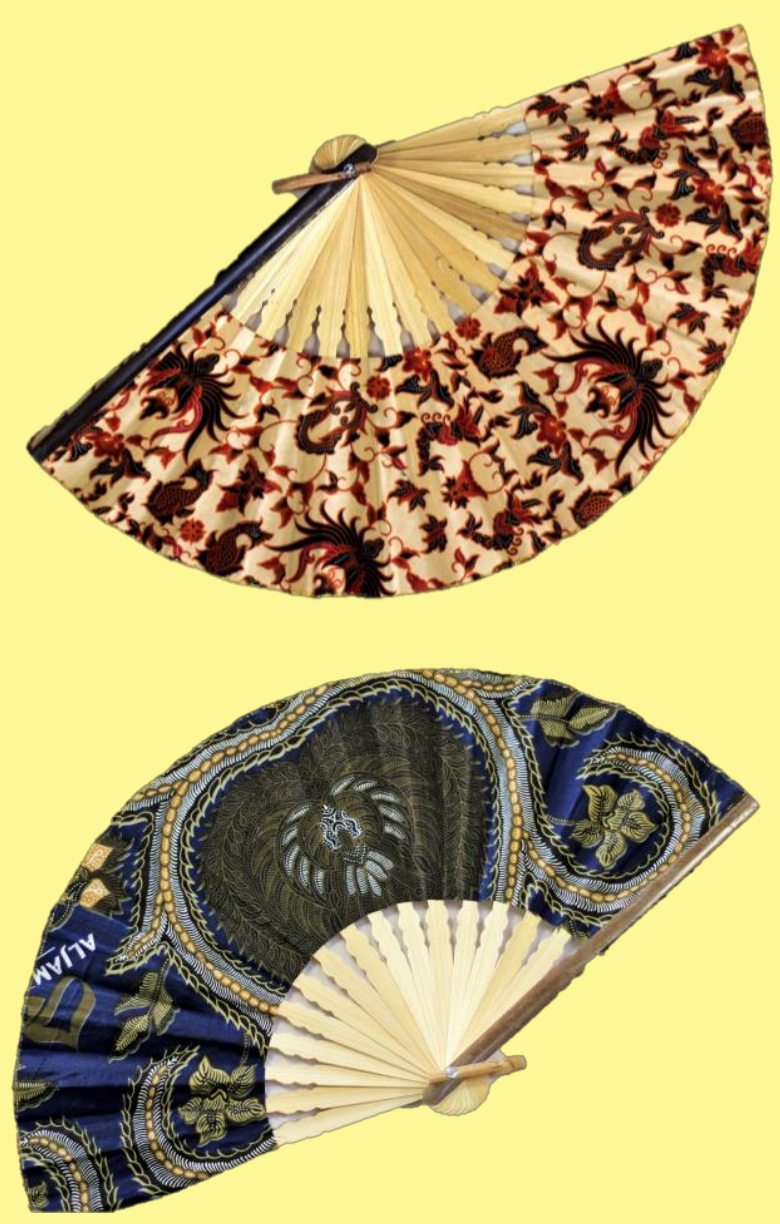


\section{CRONiSTAS hispánicos EN BALI}

“Cuando me disponía a estar de catedrático interino en Madrid, con una promesa, más o menos firme, de que me iban a dar la cátedra enseguida, me llaman por teléfono del Ministerio de Estado (...) para proponerme ir a Filipinas. (...) Me fui a Filipinas con Julio Palacios, que era ya académico de la Academia de Ciencias Exactas y estaba muy puesto en las nuevas teorías del átomo. (...) Fue un viaje muy interesante (...) Y por consejo de Neruda, que había estado en Java y Bali, hicimos la vuelta por Célebes, Bali, donde pasamos cinco días maravillosos (...)"-Gerardo Diego.

A pesar de que los viajeros hispanos no abundaron tanto como los europeos o norteamericanos en Bali, resulta sorprendente la calidad y cantidad de los testimonios sobre Bali en lengua castellana, ya sea en revistas ilustradas (como la argentina Caras y Caretas) o en periódicos de carácter local.7 Además del ya mencionado mexicano Miguel Covarrubias (1904-1957), el gran autor sobre Bali, la isla fue objeto de extrañeza y admiración en publicaciones hispánicas de todo el globo. Para la mayoría de visitantes, Bali fue una breve, pero singular parada en largos viajes de vuelta al mundo. Por ejemplo, el poeta Gerardo Diego y el físico Julio Palacios, eminencias en sus respectivos campos, que viajaron en 1935 a Filipinas para impartir unas conferencias en el Ateneo Español de Manila decidieron hacer parada en Bali por sugerencia de Pablo Neruda, que acababa de ser cónsul de Chile en Batavia (Java) y ya conocía los encantos de la isla. Además del consejo, Neruda también prestó a Diego el traje con el que aparece en la fotografía. A pesar de la brevedad de su estancia, Bali dejó una huella notable en ambos viajeros. Mientras que Gerardo Diego (1896-1987) mencionó la isla en poemas como Lokang (Boceto para un poema de Bali) (1956), ${ }^{8}$ el aragonés Julio Palacios Martínez (1891 - 1970), nacido en Paniza, dejó al respecto un interesante testimonio, publicado en un libro que escribió al respecto de su viaje (su única

7 Imperio: Diario de Zamora de Falange Española de las J.O.N.S.: Año VII, $\mathrm{n}^{\circ}$ 1626, 19 de marzo de 1942

8 «Lokang (Boceto para un poema de Bali)» [La memoria, Lokang, la memoria.], Cuadernos de Ágora, $\mathrm{n}^{\mathrm{O}}$ 1-2, noviembrediciembre de 1956, pp. 4-5. obra fuera el ámbito científico): Filipinas, orgullo de España: un viaje por las islas de Malasia (1935), que fue elogiado por Ortega y Gasset y reeditado hace unos años. 9

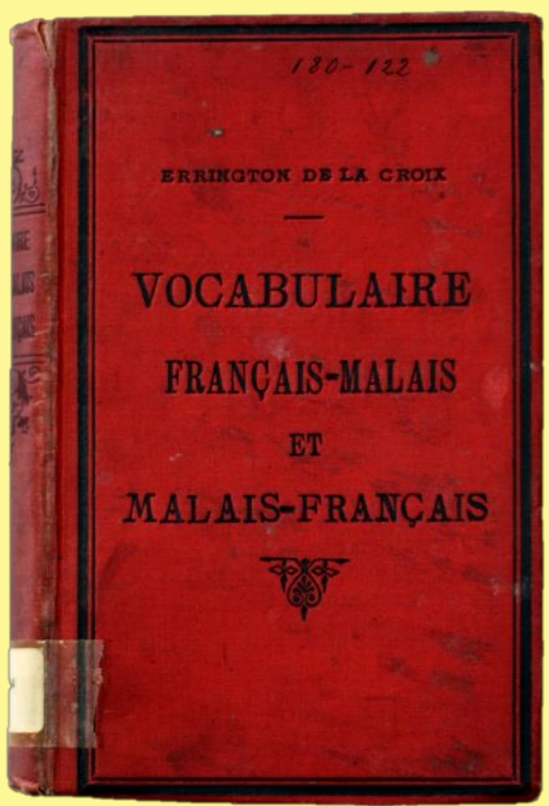

Libro Vocabulaire français-malais e malais-français (Errington de la Croix, París, Ernest Leroux, 1889). Colección de la Biblioteca de la Universidad de Zaragoza.

9 Palacios, Julio. Filipinas, orgullo de España: un viaje por las islas de la Malasia. Zaragoza, Diputación General de Aragón, 1998. 


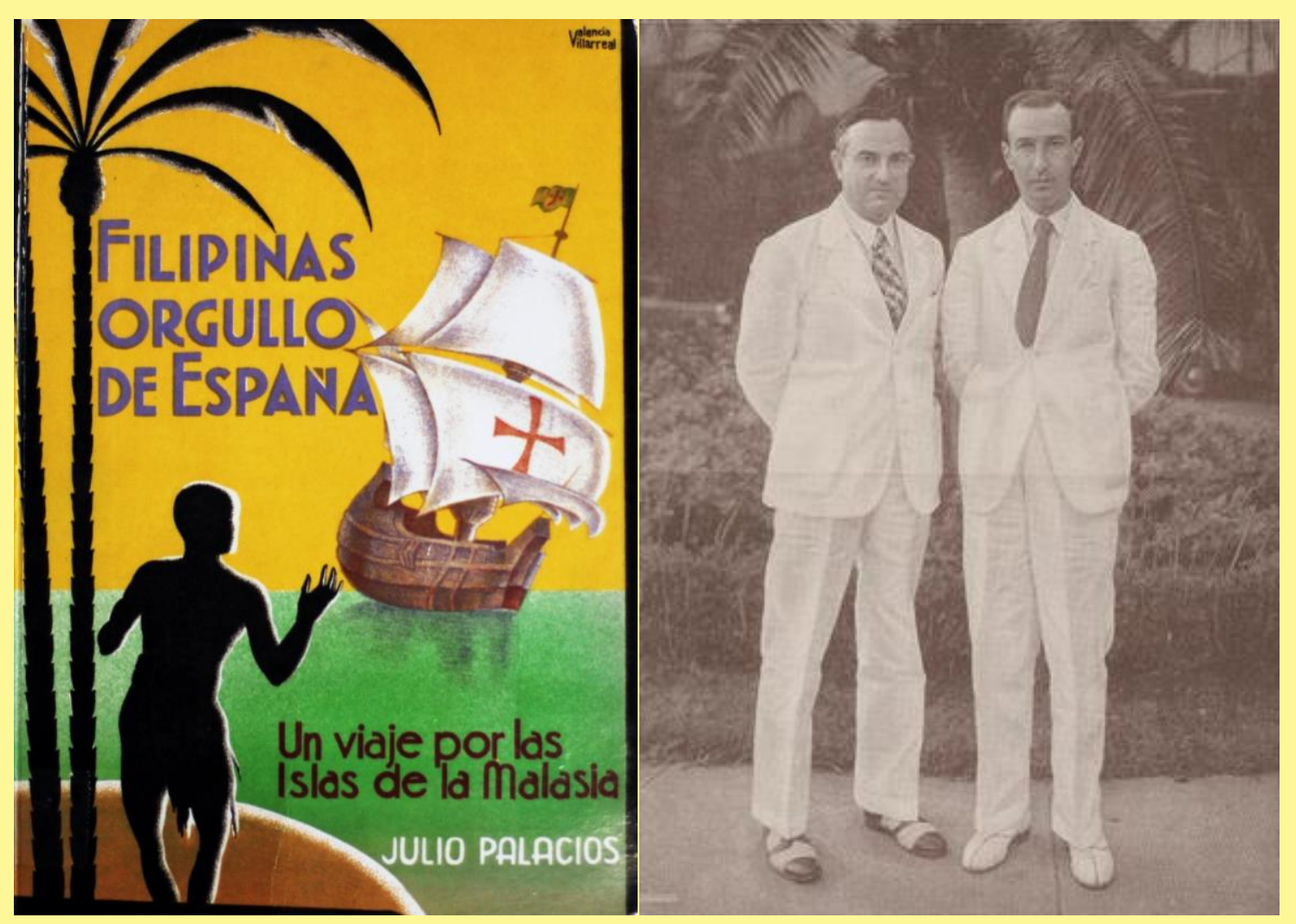

A la izquierda, Filipinas, orgullo de España: un viaje por las islas de la Malasia (Palacios, Julio, Zaragoza, Diputación General de Aragón, 1998). Colección de la Biblioteca de la Universidad de Zaragoza. A la derecha, Palacios y Gerardo Diego durante su viaje por Extremo Oriente, tal como aparecieron en un diario de Manila

Considerado hoy como uno de los más relevantes físicos españoles, Julio Palacios era en aquellos momentos doctor por la Universidad Central de Madrid, había estudiado en Leiden y trabajado con Blas Carrera, sido catedrático de Termología en la Universidad de Madrid, miembro de la Real Academia de Ciencias Exactas, Física y Naturales y director de la novedosa sección de Rayos x del Instituto Nacional de Física y Química. En su libro, dentro del capítulo "Bali, la perla de Insulindia", Palacios no duda en denunciar las artimañas con las que holandeses y norteamericanos intentan estafar a los turistas; no obstante, repite muchas de las visitas clave de la mayoría: templos (como el de Goah Gajah o Goa Lawah, palacios (como el Kerta Gosa), mercados, cremaciones y danzas, e incluso llega a coincidir con el bailarín I Mario, el más famoso del momento. No obstante, el relato de Palacios destaca por su detalle y franqueza, así como por el uso de fuentes secundarias que seguramente leyó durante la redacción del libro. Tras su viaje a Bali, que coincidió con el estallido de la Guerra Civil, Julio Palacios comenzó a interesarse por la biología y cuando desarrollaría su famosa postura crítica hacia la teoría de la relatividad. Pero eso ya es otra historia.

Por su parte, Baudilio Alió fue un pintor y escritor hispano-argentino (con ambas nacionalidades figura en las crónicas), nacido en Chile y descendiente de un empresario y arquitecto catalán del mismo nombre que a finales del siglo XIX se asentó en Asunción y que construyó el actual Teatro Nacional del Paraguay en 1886. Poco ha trascendido de la vida de nuestro Alió, excepto que fue un pintor y caricaturista de fama en la Buenos Aires de la década de los 20, y que se costeó varios viajes 


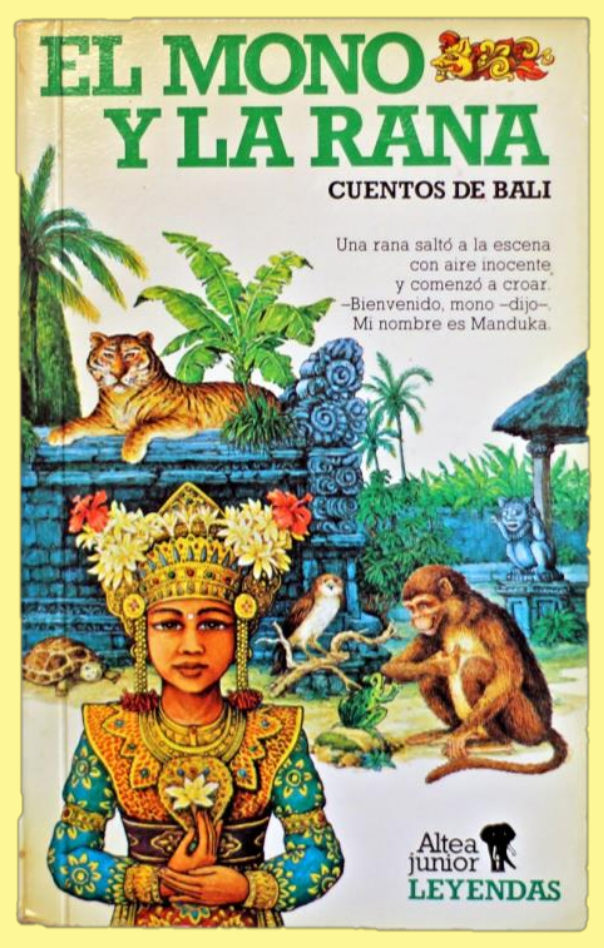

Libro El mono y la rana: leyendas de Bali (Berthier, Marie-Thérèse, Sweeney, John-Thomas y Mignon, Philippe, Madrid, Ediciones Altea, 1986).

regiones. En cuanto a Bali, se concentra en describir la religión y la danza, aspecto que sobrecogía a la mayoría de visitantes extranjeros. Además de las informaciones que aparecen

${ }^{10}$ Alió, Baudilio. Tras la ruta del Sol (la vuelta al mundo de un pintor). Buenos Aire, Talleres Gráficos Argentinos, L.J. Rosso, 1931.

${ }^{11}$ Martorell Téllez-Girón, Ricardo. Trece crónicas de viaje por China, Mongolia, Japón, Filipinas, Bali, Siam y la India. Madrid, Estanislao Maestre, 1933. Esta obra se encuentra libre de derechos de autor y puede consultarse libremente en línea en la Biblioteca Nacional Hispánica. Por su relevancia, incluimos el capítulo balinés en este catálogo. en su libro, poco más se sabe de su vida hasta la Guerra Civil, que le sorprende en Barcelona y en la que, con discreto anonimato se alista en la Legión. Fallece en la Batalla de Sabiñánigo en otoño de 1937, dejando poco más que una nota para su enamorado Nacho que fue publicada en varios periódicos. Ninguno de sus compañeros conocía sus orígenes hasta que su madre se presentó a reclamar el cuerpo.

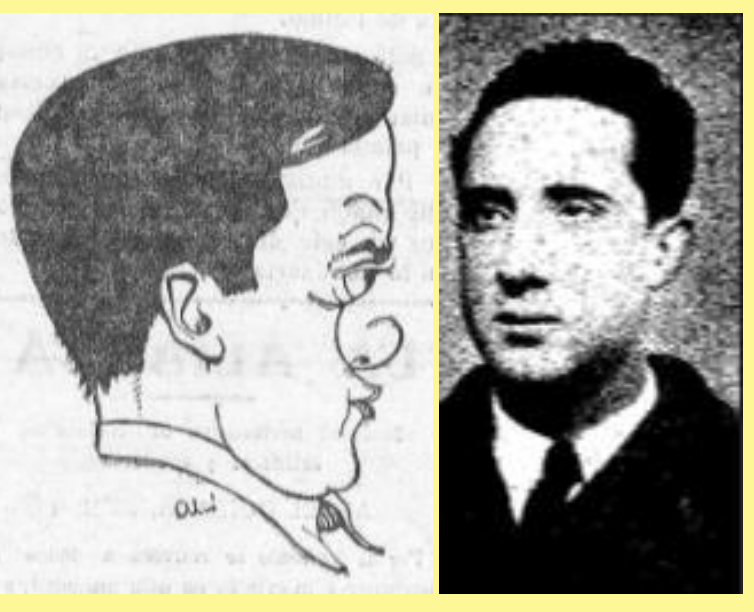

A la izquierda, Baudilio Alió, autocaricatura; a la derecha, Una de las pocas fotos que se conservan de Ricardo Martorell Téllez-Giron, Marqués de Monasterio. 


\section{LA VIDA COTIDIANA EN BALI}

Hablar de vida cotidiana en Bali es hablar de la importancia de la tradición religiosa, que envuelve absolutamente todos los aspectos de la vida desde el nacimiento a la muerte. La herencia más fuerte del hinduismo en Bali se percibe en su obsesión por la jerarquía. Ante la apariencia de un lugar caótico, abarrotado y desordenado, todo está regido por un montón de reglas que condicionan absolutamente todos los aspectos del día a día.

El cultivo y negocio del arroz rigió el día a día de los balineses durante miles de años, así que las principales aldeas se organizaron teniendo en cuenta las fuentes de agua y sus corrientes. En muchos casos, ni siquiera puede hablarse de núcleos de población sino de una serie de viviendas que comparten instalaciones comunes (esencialmente, templos, en los que también se llevan a cabo actividades de reunión y gobierno), cuyos hombres adultos deben formar parte de una asamblea comunitaria si no quieren verse condenados al ostracismo. Las viviendas son, en realidad, una serie de pabellones rodeados por un recinto, en los que cada una de las habitaciones (de un solo piso, a veces elevado sobre el suelo y con poca luz y ventilación) es un bloque separado al que debe accederse por el jardín, sin ningún tipo de pasillo o espacio cubierto, estructura muy similar a la de los templos. Todo esto puede realizarse con más o menos lujo, pero la misma estructura se repite en palacios y viviendas prefabricadas, en incluso en muchos hoteles modernos.

Hace cientos de años, el hinduismo trajo consigo un sistema de castas y jerarquía muy marcado, de obligado seguimiento hasta la conquista holandesa, que dividía a la población en los grupos brahmán (asociados a la religión), tsatria (la nobleza gobernante), wesia (la clase militar) y tsudra (el pueblo llano). No obstante, muchas actividades que en otros lugares hubieran estado mal consideradas entre las clases altas, como la música, la carpintería o la venta ambulante, fueron y son practicadas de manera profesional por miembros de la alta cultura balinesa. Si bien hoy la casta no condiciona completamente el día a día, sí que está presente en los nombres tradicionales. El balinés, históricamente carece de apellido (aunque hoy muchos adoptan uno para facilitar trámites), tiene siempre un nombre que consta de varias partículas (un mínimo de tres), aunque puede decidir hacerse conocer solo con algunas de ellas. Observando el nombre de un balinés podemos intentar adivinar su pasado familiar: p. e. de la bailarina Ni Polock podemos saber que era de origen humilde, mientras que del pintor Anak Agung Gdé Sobrat podemos decir que pertenecía al alto funcionariado y que era el cabeza de familia, o del artista I Gusti Nyoman Lempad, que era el tercer hijo de una familia de la baja nobleza. Ninguno de ellos vivió en un periodo en el que les fuera necesario adoptar un apellido. Esto explica que, para los extranjeros, la mayoría de nombres balineses suenen iguales y confusos.

Otro de los ejemplos de la complejidad del hinduismo balinés que marca el día a día es el calendario. Además del calendario gregoriano solar impuesto desde época colonial, los balineses tienen dos calendarios, el saka -de tipo lunar y que dura 210 días- y el pawukon que dura 510-. Este último está formado por treinta wuku ("semanas"), que pueden ser de tres, cinco o siete días de duración. La conjunción de estos dos calendarios determinará la idoneidad de las fechas para realizar determinadas acciones o ceremonias, siendo la más importante el Nyepí (considerado el "año nuevo balinés"), en la que deben seguirse las estrictas normas de "no viajar, no 
luz o fuego, no entretenimiento y no trabajar" y en la que toda la isla permanece en silencio e inactiva.

\begin{tabular}{|l|l|l|l|}
\hline 1. Casta & $\begin{array}{l}\text { 2. Orden de } \\
\text { nacimiento* }\end{array}$ & $\begin{array}{l}\text { 3. Nombre } \\
\text { apodo }\end{array}$ & 4. iApellido? \\
\hline $\begin{array}{l}\text { Tsatria: Cocorde (familia real), Gde (cabeza } \\
\text { de clan), Anak Agung (alto funcionariado, } \\
\text { Baja nobleza: I gusti (m) / Ni gusti (f) (baja } \\
\text { nobleza) }\end{array}$ & $\begin{array}{l}\text { Primer hijo: Wayan / Putu } \\
\text { (también sirve para el } \\
\text { quinto hijo) }\end{array}$ & $\begin{array}{l}\text { Uno o dos apodos } \\
\text { Brahmán: Ida Bagus (m), Ida Ayu (f) }\end{array}$ & $\begin{array}{l}\text { Tradicionalmente no hay, } \\
\text { pero es necesario para } \\
\text { salir del país, agilizar } \\
\text { trámites, y muchos } \\
\text { jóvenes lo usan de cara a la } \\
\text { globalización. Es de libre } \\
\text { elección. }\end{array}$ \\
\hline Wesia: Dewa (m), Desak (f) & Tercer hijo: Nyoman & Topónimos & Antropónimos \\
\hline Tsudra: I (m), Ni (f) & Cuarto hijo: Ktut / Ketut & & \\
\hline *En ocasiones, la nobleza los evita. Si un hijo muere, los siguientes "ascienden". &
\end{tabular}

Cuadro que intenta explicar el complejo sistema de nombres balineses

La mayoría de estas normas y costumbres han llegado hasta nosotros por medio de la tradición oral, ya que, hasta época colonial, no había en Bali otros registros que los realizados en lontar, pequeñas "tablillas" realizadas en hojas de palma, y que se limitaban a asuntos religiosos y rituales, escritos en kawi, una forma arcaica de escribir el javanés antiguo, todavía hoy lengua litúrgica de la isla. La lengua del día a día era (y continúa siendo) el balinés, aunque con la proclamación de la República de Indonesia, se adoptó el bahasa indonesia (literalmente "lengua indonesia"), como lengua oficial, creado unos años antes a partir de varias lenguas malayas con la intención de unificar la cultura y administración de la futura nación. Durante el periodo en el que la isla recibió a sus más ilustres visitantes, la lingua franca de todo el archipiélago era el malayo, utilizado por administración y comerciantes; muchos viajeros comentaban con asombro como casi nadie en Bali hablaba holandés. Una vez que el turismo comenzó a considerarse fuente de ingresos, muchos artesanos y comerciantes comenzaron a aprender inglés y desechar progresivamente el javanés y el malayo. Si bien en las escuelas se enseña el bahasa indonesia y el inglés, no por ello se desdeñan las tradiciones locales, ya que, de los seis días lectivos, dos corresponden a cada uno de los uniformes oficiales: el occidental (con pantalón), el indonesio (al estilo javanés) y el tradicional balinés.

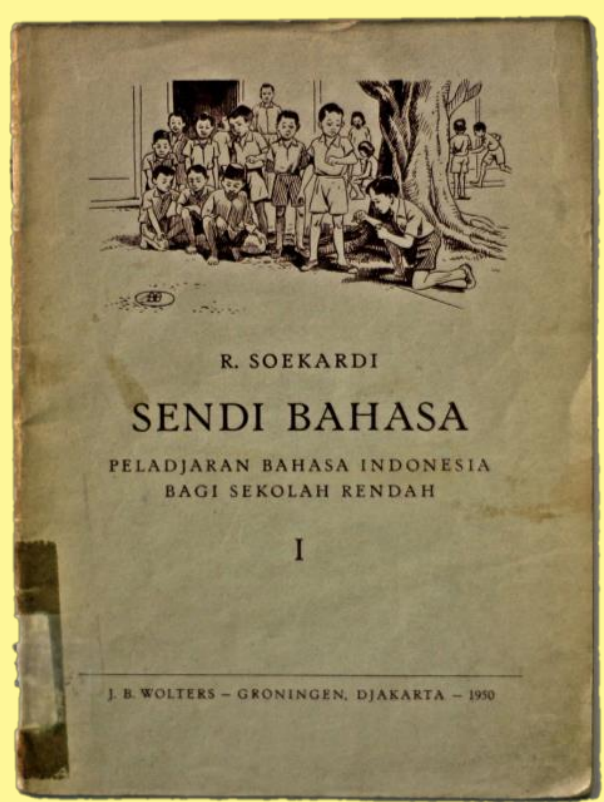

Sendi Bahasa: peladjaran Bahasa Indonesia bagi sekolah rendah (R. Soekardi, Yakarta, J.B. Wolters, 1950). Colección de la Biblioteca de la Universidad de Zaragoza.

$\mathrm{El}$ asunto de la vestimenta fue uno de los que más llamó la atención a todos aquellos que visitaban Bali: no solo hombres y mujeres adultos se arreglaban y engalanaban por igual, sino que, además, su ropas y complementos eran particularmente parecidos. El elemento tradicional del vestido era, y es, el sarong, un fragmento de tela que se enrolla alrededor de las piernas y que forma una especie de falda. Puede estar más o menos decorado y se anuda 
de forma diferente en mujeres y hombres, ya que en este caso se ata en el centro, evocando los atributos masculinos. Además de mediante nudos y rollos, este puede fijarse mediante otras telas o fajines colocadas con presión, y prescriptivas en el caso de la danza. Tradicionalmente, los balineses iban descalzos (hoy, rara vez aguantan algo que no sean sandalias, aun cuando el clima sea frío) y desnudos de cintura para arriba, lo que hacía las delicias de muchos visitantes. La excepción llegaba al entrar al templo o realizar actos rituales, pues ahí hombres y mujeres cubrían sus torsos con algún tipo de blusa o camisa. La más popular hoy, desde que los holandeses prohibieran la desnudez parcial es la kebaya, un tipo de blusa ajustada y escotada, que puede realizarse en diferentes colores y materiales y que se lleva con un contrastado fajín. La principal diferencia reside en la forma de presentar la cabeza. Tradicionalmente, las mujeres dejaban su cabello largo y lo recogían en diferentes peinados, profusamente adornados, ya fuera con telas o pequeños complementos.

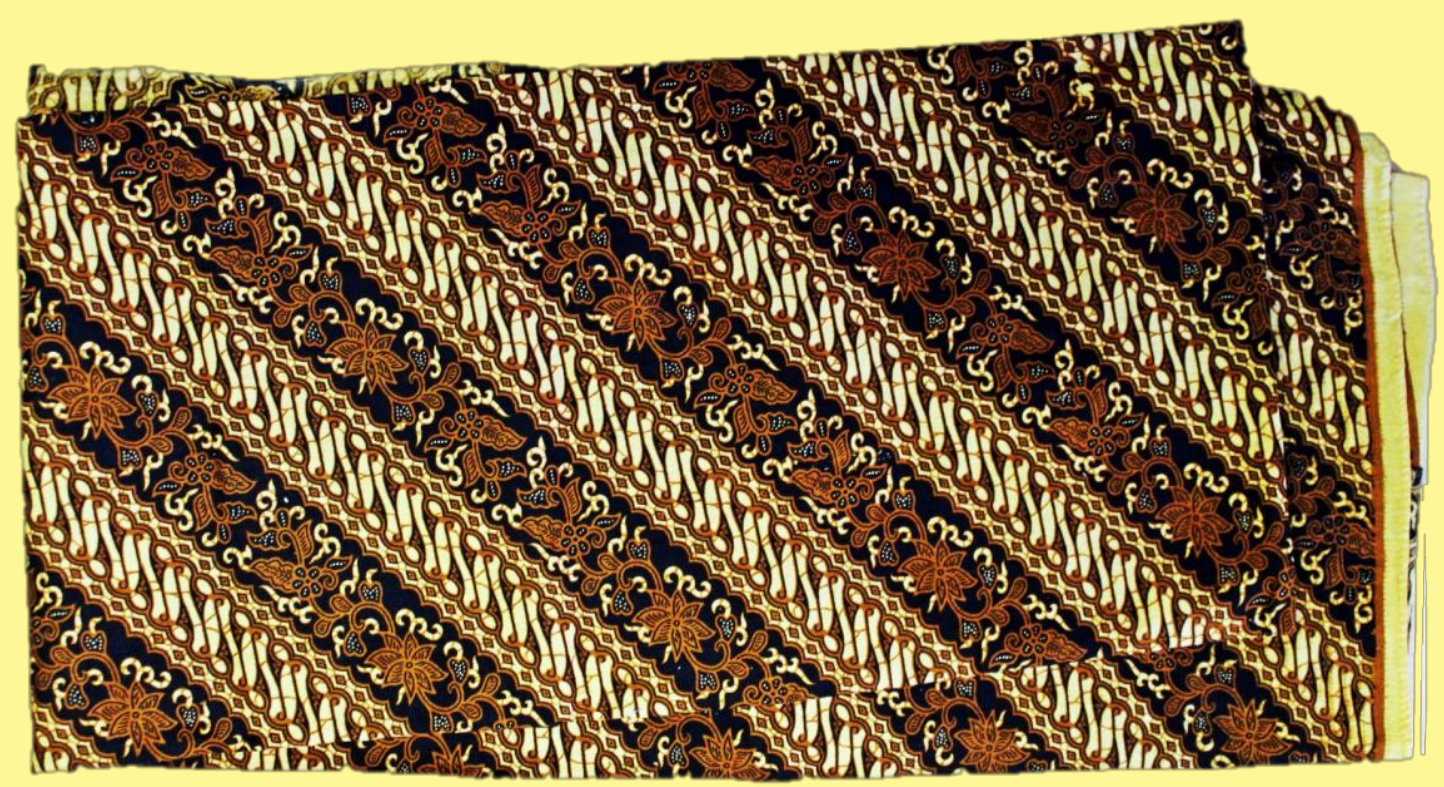

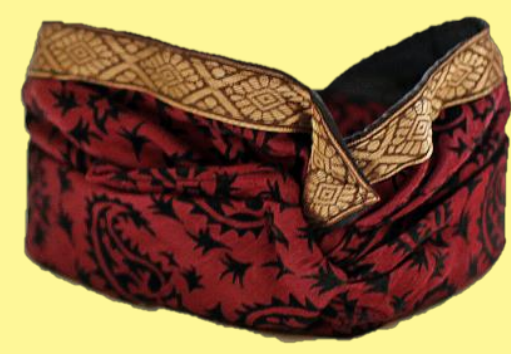

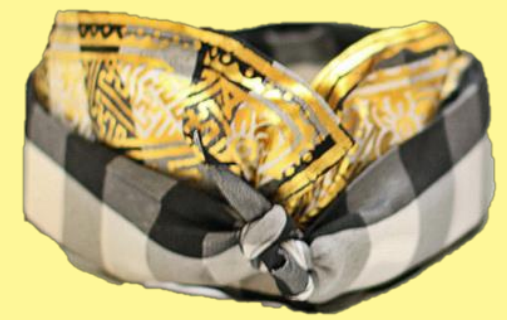

A la izquierda, tela de batik de estilo javanés. Textil. S. XXI. Colección particular. Sobre estas líneas, diferentes udengs de uso cotidiano (el de abajo, con estampado saput poleng). Textil, S. XXI. Colección particular.

Sin embargo, los hombres portaban (y portan) el udeng, un trozo de tela enrollado primorosamente anudado en uno de sus extremos (hoy se fabrican y venden ya anudados). Complemento unisex son las flores, que se colocan en el cabello o tras la oreja, siendo especialmente apreciadas y comunes las plumerias o frangipani, que figuran no solo en la vestimenta sino en la mayoría de las ofrendas. 


\section{LA RELIGIÓN EN BALI}

"Se ha llegado a decir de los balineses que son el pueblo más piadoso de la tierra. Desde su nacimiento hasta su muerte no piensan más que en adorar a las potencias místicas que los dominan, a fin de establecer entre ellos y ellas una feliz y santa armonía." Revista Caras y Caretas, 1932.

Bali es, probablemente, uno de los lugares más religiosos del mundo. La religión no solo inunda la esfera pública de la isla, sino que la espiritualidad está profundamente arraigada en la mayoría de actos de la vida cotidiana, a pesar de la globalización y el turismo masivo. Una de las mayores particularidades de la isla es su religión hinduista que, llegada probablemente hace casi dos mil años desde el sur de la India, se fusionó con elementos autóctonos, a los que se agregaron algunos elementos budistas durante el periodo de las talasocracias indobudistas (ss. VIII - XII), como el Imperio de Srivijaya, muestra de lo cual quedan todavía templos en Bali, como la popular Goa Gajah, o Cueva del Elefante. Estas singularidades se reforzaron a partir del s. XIV y especialmente desde el s. XVI, momento en que, tras la conquista islámica de la gran mayoría de las cortes importantes de Sumatra, Borneo y Java -de las que Bali dependía cultural y económicamente-, muchos de sus nobles $\mathrm{y}$ artistas se refugiaron en la isla. No obstante, hay que tener en cuenta que, tras el asentamiento colonial holandés y, especialmente tras la Independencia de Indonesia (que permitía libertad religiosa pero solo reconocía los cultos monoteístas), la religión balinesa ha sufrido importantes adaptaciones, como el auge del culto a Acintya, considerado como Dios supremo y del cual las otras deidades no son sino encarnaciones.

Así pues, muchas nociones del hinduismo (como las ideas de dharma, reencarnación o la omnipresencia de demonios, de los que hay que proteger cualquier ámbito público y privado) son elementales para comprender la espiritualidad de la isla, pero estas son tamizadas por la presencia de creencias y personajes locales. Por ejemplo, algunos de los dioses más venerados tradicionalmente han combinado elementos hinduistas con otros locales, como es el caso de Dewi Sri, deidad del arroz y Diosa Madre por excelencia.
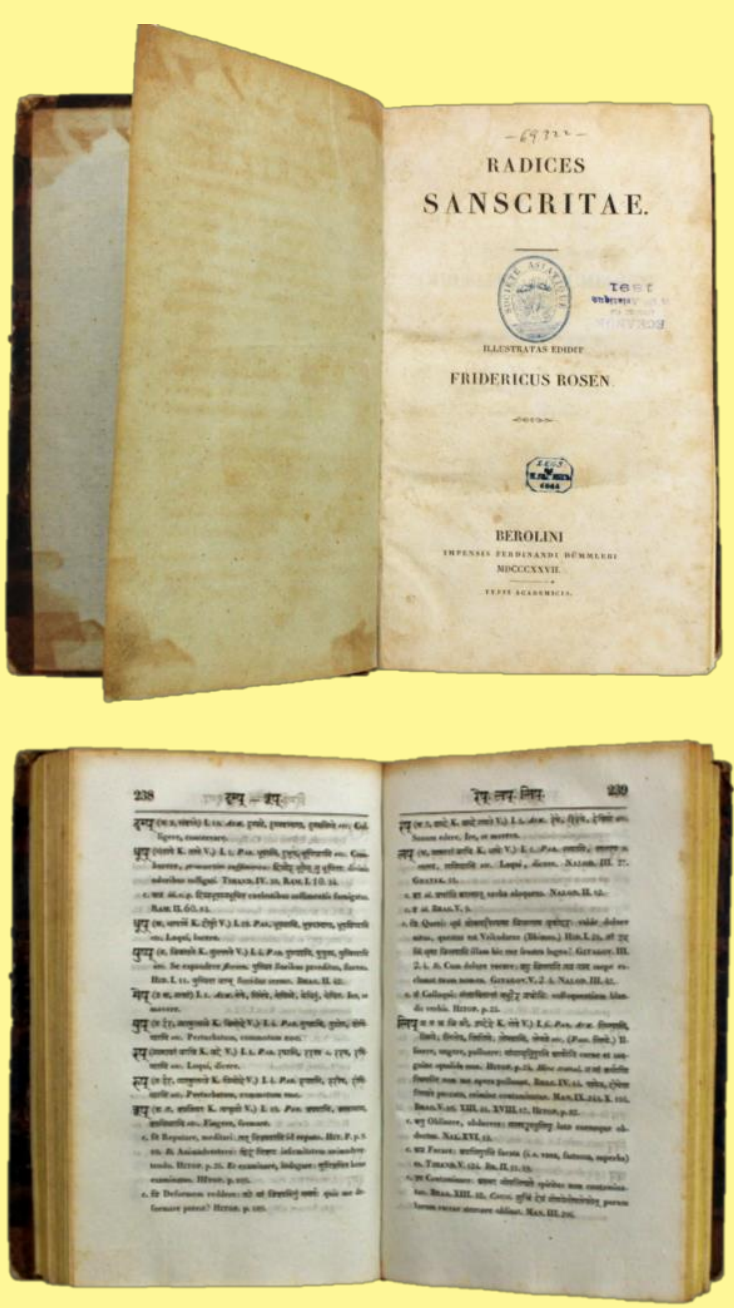

Radices sanscritae. Illustratas edidit Fridericus Rosen (Rosen, Friedrich August, Berlín, Impensis Ferdinandi Dümmleri, 1827), Colección de la Biblioteca de la Universidad de Zaragoza. 


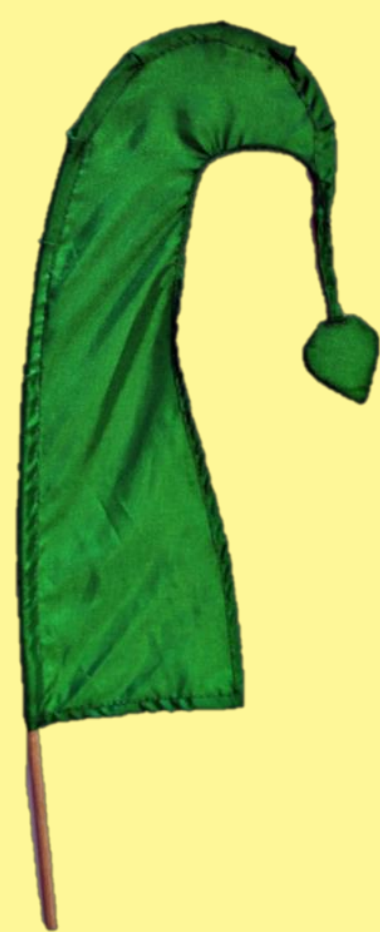

Penjor ornamental o de tipo comercial. Madera y Textil. $S$. XXI. Colección particular.

Su nombre, que proviene del sánscrito no significa otra cosa que "Diosa sagrada", pero al ser diosa del arroz (el alimento básico en Bali y base de su economía), lo es también, por extensión, de la fertilidad, la prosperidad, la riqueza, $\mathrm{y}$, la vida, $\mathrm{y}$, por tanto, tiene también control sobre sus opuestos (la pobreza, el hambre, la muerte...). Su culto es omnipresente y sus representaciones adoptan múltiples formas, desde las ahora casi desaparecidas estatuillas hechas con kepeng -monedas chinas-, que refuerzan la idea de la prosperidad, a las omnipresentes tjilís, figuras femeninas estilizadas que aparecen en altares y ofrendas de todo tipo, hechas en materiales tan variados como la hoja de palma (lontar) o pasteles de arroz glutinoso. Su figura está tanto o más presente que otras más asociadas a las artes plásticas o escénicas, como el Rangda y Barong (que dejan ver la obsesión balinesa por el tema de la magia, y los demonios como los hyang o leyaks) o los personajes de los ciclos literarios hinduistas como Arjuna o Rama.

En realidad, arte, espectáculo y religión son tres conceptos que no pueden entenderse de forma separada en Bali. Además, muchas de sus manifestaciones artísticas son el producto de las diversas oleadas migratorias que ha tenido Bali a lo largo de la historia, y que han tenido un diferente componente étnico, religioso y cultural. Por ejemplo, son muy valorados por su carácter decorativo los títeres balineses y javaneses, especialmente los de wayang golek, que en realidad son mucho menos habituales que los de wayang kulit o wayang klitik. Gran parte de los espectáculos musicales y teatrales de Bali tienen su origen cultural en Java, y datan casi siempre de época Mahapajit, momento en el que la tradición hinduista adoptó sus formas artísticas actuales. Así pues, la mayoría de las historias que se representan en las obras de teatro provienen de los grandes textos épicos hinduistas, como el Ramayana y el Mahabharata, probablemente redactados en India durante el s. III a.C. Las historias de los dioses, demonios y héroes hinduistas llegaron a Java y Bali algo más tarde, adaptándose su representación a la moda cortesana javanesa del momento. Así pues, los títeres que representan a personajes del Ramayana

como Rama y Sita (conocidos en Bali conjuntamente como

Ramasinta) o del

Mahabharata, como Arjuna o Dewi Kunti, van vestidos $\mathrm{y}$ tocados como la nobleza javanesa de los siglos XIII-XV.

Estatuilla de la diosa Dewi Sri. Madera policromada, monedas kepeng y cuerda. S $X X$. particular.

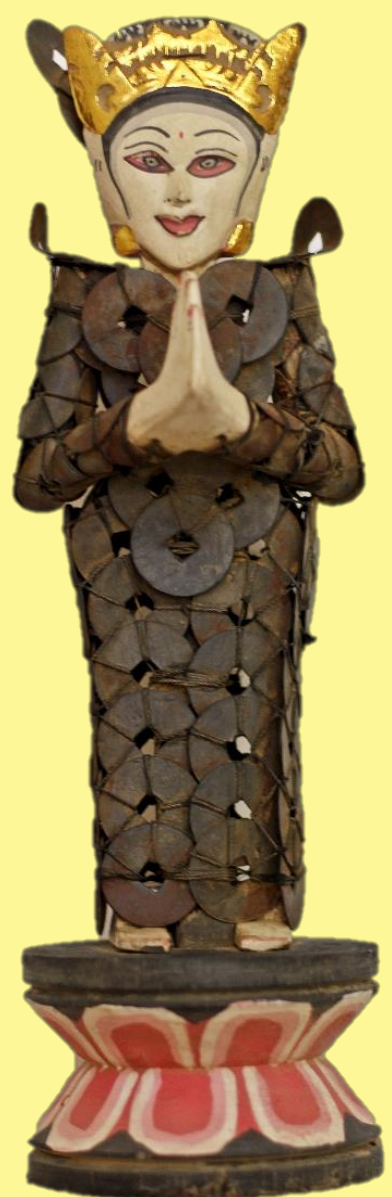



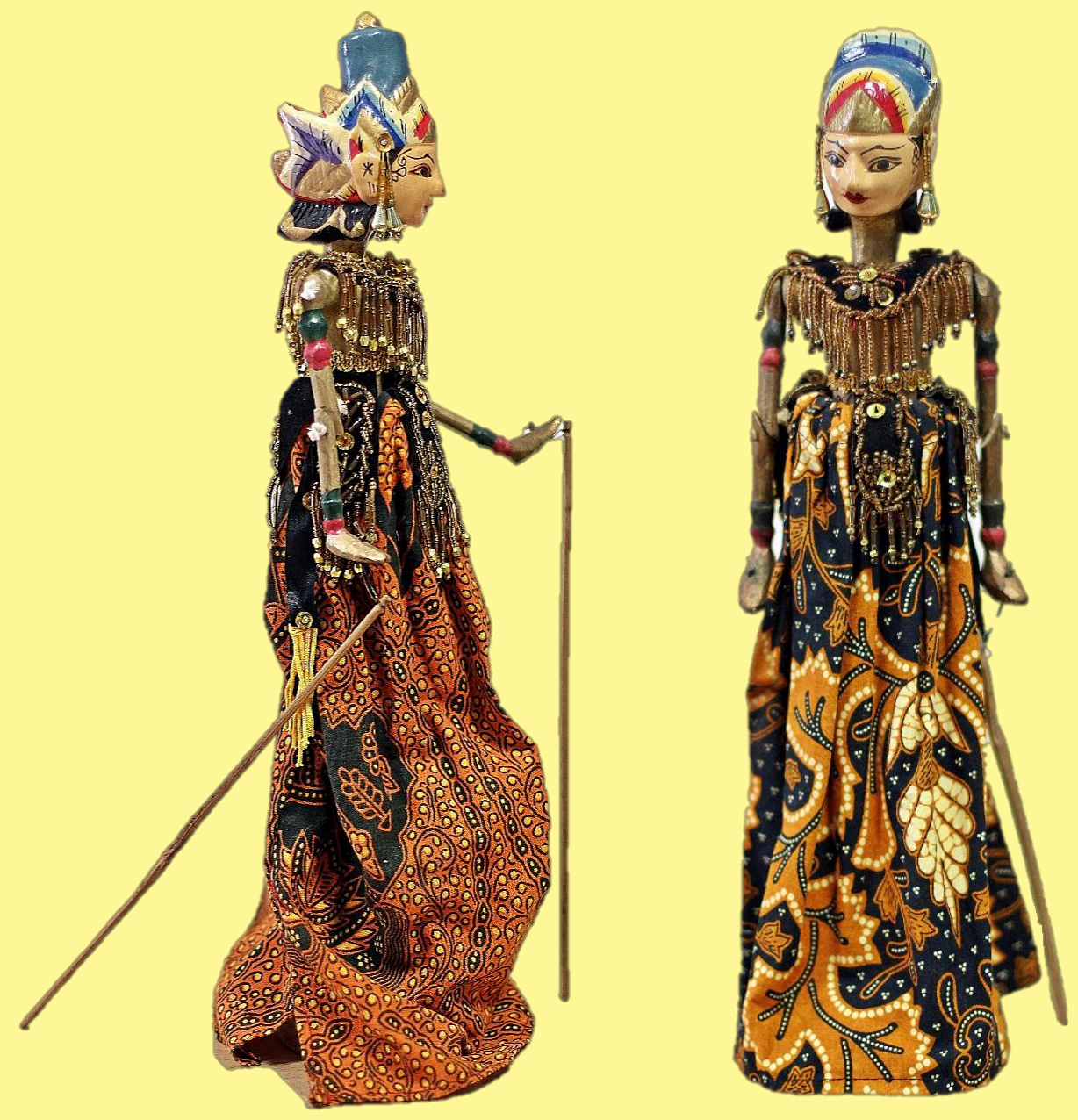

Marionetas para wayang golek (Ramasinta, Rama y Sita). Madera policromada, textil y apliques decorativos. Década de 1980. Colección particular.
Algunos autores han llamado a Bali, y no sin razón, la "isla de los dioses" o, incluso la "isla de los demonios”. Lo cierto es que los templos, altares y objetos sacralizados o considerados sagrados (como el warigin, una higuera de Bengala que ocupaba una posición principal en las aldeas) existen con una profusión que no se da en ningún otro lugar del planeta: no solo cada comunidad tiene, como mínimo, tres templos (pues sus funciones se reparten según su advocación); cualquier casa de cierto nivel económico tendrá también una zona de templo, así como cada hotel o centro comercial deberán tener, al menos, uno. Por pequeña que sea la casa, negocio o incluso puesto callejero, nunca faltará un pequeño altar en el que se coloquen tjilís y se hagan ofrendas de incienso, flores $\mathrm{y}$ otros elementos (como dinero, comida o incluso cigarrillos) un mínimo de tres veces al día, y, así mismo, se dejaran ofrendas en cada entrada y salida de un edificio o recinto (por pequeño que este pueda ser), para disuadir a los demonios de entrar; muchas veces se colocarán estatuas de guardianes para reforzar esta función. Tan importante es el tema de las ofrendas que una de las ocupaciones tradicionales de las mujeres era la confección diaria de muchas de las pequeñas ofrendas de suelo: el auge de la vida moderna y la incorporación de la mujer al mundo laboral de fuera de casa ha hecho que surjan ahora creadoras de ofrendas 
especializadas, que surten a negocios y hoteles. Los altos y llamativos penjor de bambú que decoran calles y templos durante buena parte del año también han encontrado su versión artificial y desacralizada y de carácter decorativo.

Además de altares y ofrendas, Bali está especialmente salpicado de templos, de diferente tamaño, calidad y condición. Con algunas excepciones, la mayoría son recientes o están muy renovados, debido a la fragilidad de los materiales utilizados. Muchos de ellos están asociados a elementos naturales, como el templo de Uluwatu, en lo alto de una gran roca al sur de Bali, del que se dice que es el barco petrificado de Dewi Danu -diosa del agua- y habitado por macacos (a los que se deja hacer a sus anchas por considerarse el ejército del dios Hanúman), o el de Tanah Lot, custodiado por venenosas serpientes marinas, pero sin duda el más famoso e importante es el Pura Besakih, considerado el templo madre de todo Bali. Considerado como una encarnación del agresivo volcán Agung, a cuyos pies se sitúa y cuyas erupciones lleva siglos soportando, es famoso por su tamaño y su gran cantidad de capillas o altares.

El templo balinés típico está compuesto por una serie de elementos recurrentes, como plataformas cubiertas (balé), torres con varios pisos (meru) o altares que pueden variar en cada caso. Como mínimo, cada templo tendrá, al menos, tres niveles de acceso: cuanto más lejos del exterior y del suelo esté un elemento, más sagrado e importante se considerará. Todos los elementos de un templo son módulos separados, pero siempre están rodeados de algún tipo de cerca que los define como terreno sagrado y por una gran puerta al cual no podrá accederse con el pecho ni las piernas descubiertas. En el patio exterior suelen desarrollarse actividades comunitarias, como comidas, festividades o danzas, y muchas veces este acoge la cocina. En el patio intermedio -el ultimo al que se suele poder acceder libremente- suele ubicarse la orquesta, así como el balé kulkul (la torre con el tambor de bronce que hace las veces de campanario); en el patio interior, al que muy pocos y en raras ocasiones se puede acceder, suele haber balés para cantos, ofrendas, reliquias, altares de familias donantes, así como, el menos, un padmasana o trono vacío, alta e intrincada estructura dedicada a Acintya. Algunos templos (especialmente, los relacionados con el reparto del agua, vital en una cultura de regadío), también pueden disponer de piscinas de baño y purificación, como es el caso de Tirta Empul o Tirta Ganga.
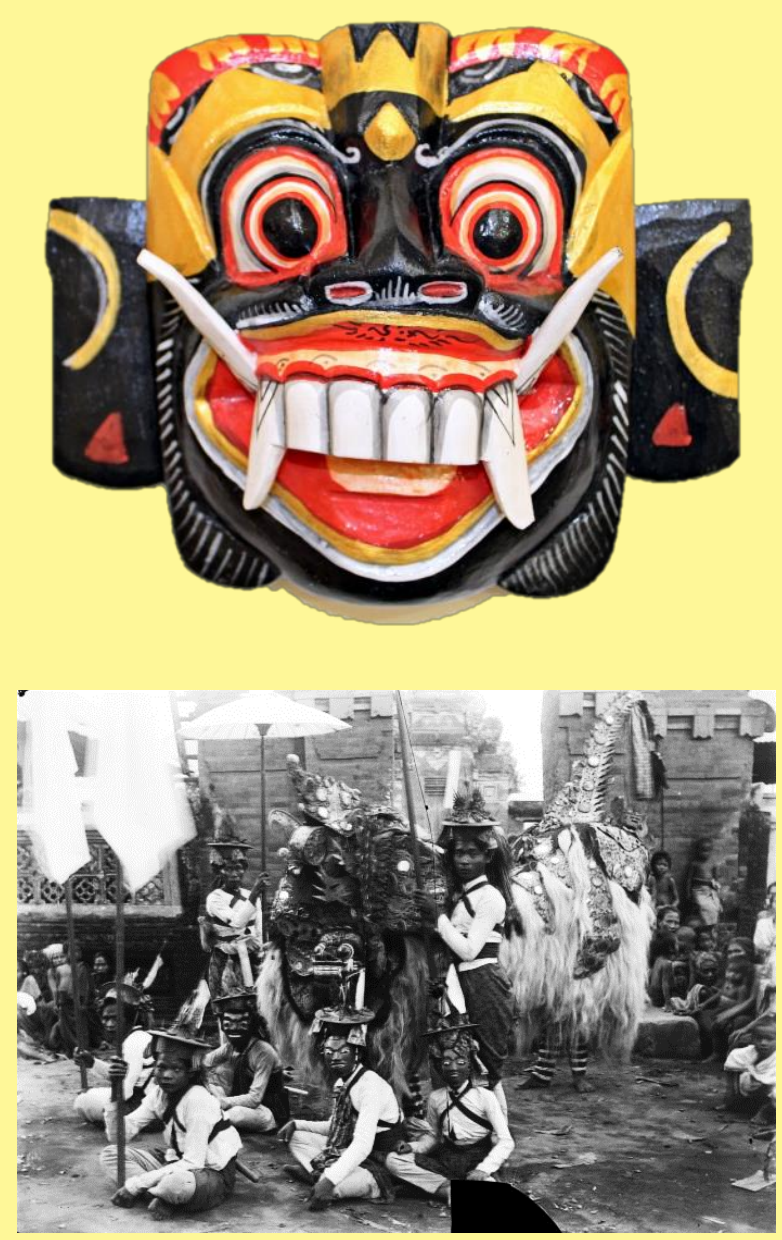

Arriba, Máscara tallada decorativa, estilo topeng. Madera policromada.S. XXI. Colección particular. Debajo, danza del Barong en Ubud (1910-1930), Fotografía de TROPPENMUSEUM, $n^{\circ} 10026826$. 


\section{LAS ARTES EN BALI}

"En Bali parecería que todo el mundo es artista. Príncipes y culís, campesinos y sacerdotes, hombres y mujeres por igual (...) Hasta hace algunos años, los balineses no hacían pinturas ni estatuas sin propósito definitivo. Mucho se ha dicho que no existen palabras en la lengua balinesa para decir "arte" ni "artista". Esto es cierto y tiene lógica; hacer una ofrenda hermosa, labrar la entrada de piedra de un templo y hacer un conjunto de máscaras son labores de igual importancia estética y aunque al artista se le considera miembro preferido de la comunidad, no existe una clase exclusiva de artistas" - Miguel Covarrubias (1937).

A pesar de la omnipresencia y valor del arte en Bali, existen en la isla muy pocos museos (tanto públicos como privados) que se dediquen a salvaguardar su importante patrimonio tradicional. Si bien es difícil distinguir entre arte y artesanía en Bali por los motivos que ya expusiera Covarrubias, las manifestaciones artísticas balinesas reúnen un amplio conjunto de disciplinas que fueron evolucionando junto al devenir histórico de la isla.

Así, remanentes de un primer periodo son las tïlís de toda clase, así como algunas tallas y motivos ornamentales presentes en aldeas del interior: lo mismo podría decirse de las ofrendas monumentales o de la cestería, que repite motivos ya milenarios. La posterior diáspora de los Mahapajit provocó un florecimiento económico y cultural que dotó a la isla de algunas de sus manifestaciones artísticas más características y sobresalientes, como el teatro de títeres o la pintura religiosa, además de buena parte de la escultura, orfebrería y arte textil. No obstante, el mayor cambio en las artes de la isla se produjo en las primeras décadas del s. XX, cuando a ella llegaron artistas y visitantes extranjeros y comenzó a haber, por primera vez, una noción no utilitaria del arte y la artesanía, que desligó, por primera vez, del marco ritual y religioso.

Una excepción sería, tal vez, la arquitectura, prácticamente inmutable desde hace varios siglos y que, con mejor o peor factura, ha repetido modelos muy similares en viviendas, templos y edificios comunitarios hasta época muy reciente. Compartimentada, jerarquizada, con techos bajos, pocas luces y ventanas y destinada a realizar la mayoría de actividades en el exterior, la arquitectura balinesa es un elemento perfecto para entender muchas de las características de su sociedad, inmutable desde hace siglos.

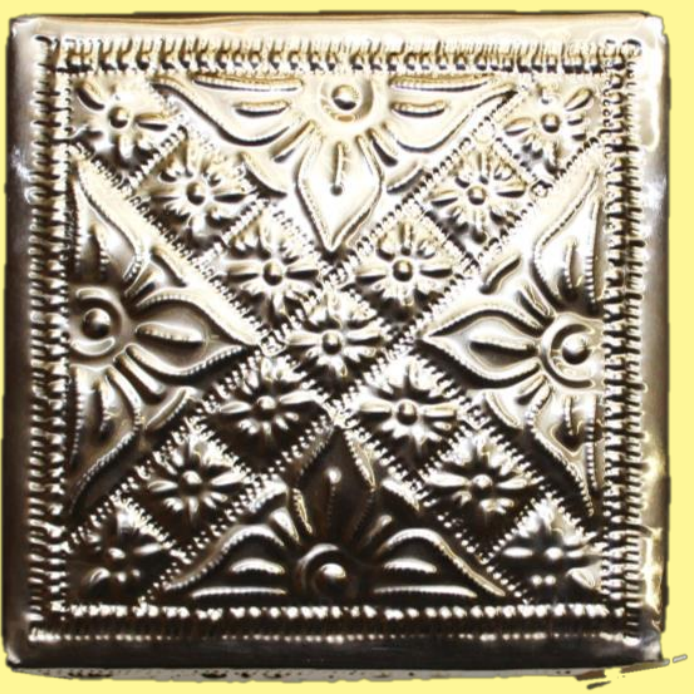

Caja con decoración tradicional de estilo arquitectónico. Hojalata. S. XXI. Colección particular.

En lo que refiere a la pintura, hasta principios de siglo XX únicamente existía un estilo tolerable, el conocido como estilo Kamasan (debido a la aldea en donde se realizaban las mejores obras) o wayang (por el parecido de sus figuras a las del teatro), de carácter religioso y que seguía reglas muy estrictas. Destinado a templos y partes nobles de palacios, trataba 
temas hinduistas o locales (como el ciclo del príncipe Panji), que se pintaban sobre tela o ulatanga (un papel realizado con cortezas), utilizando muy pocos colores y con un estilo bidimensional. En aquellos momentos, no existían una noción "artística" sobre estas pinturas, que se realizaban de manera colectiva para un bien común.

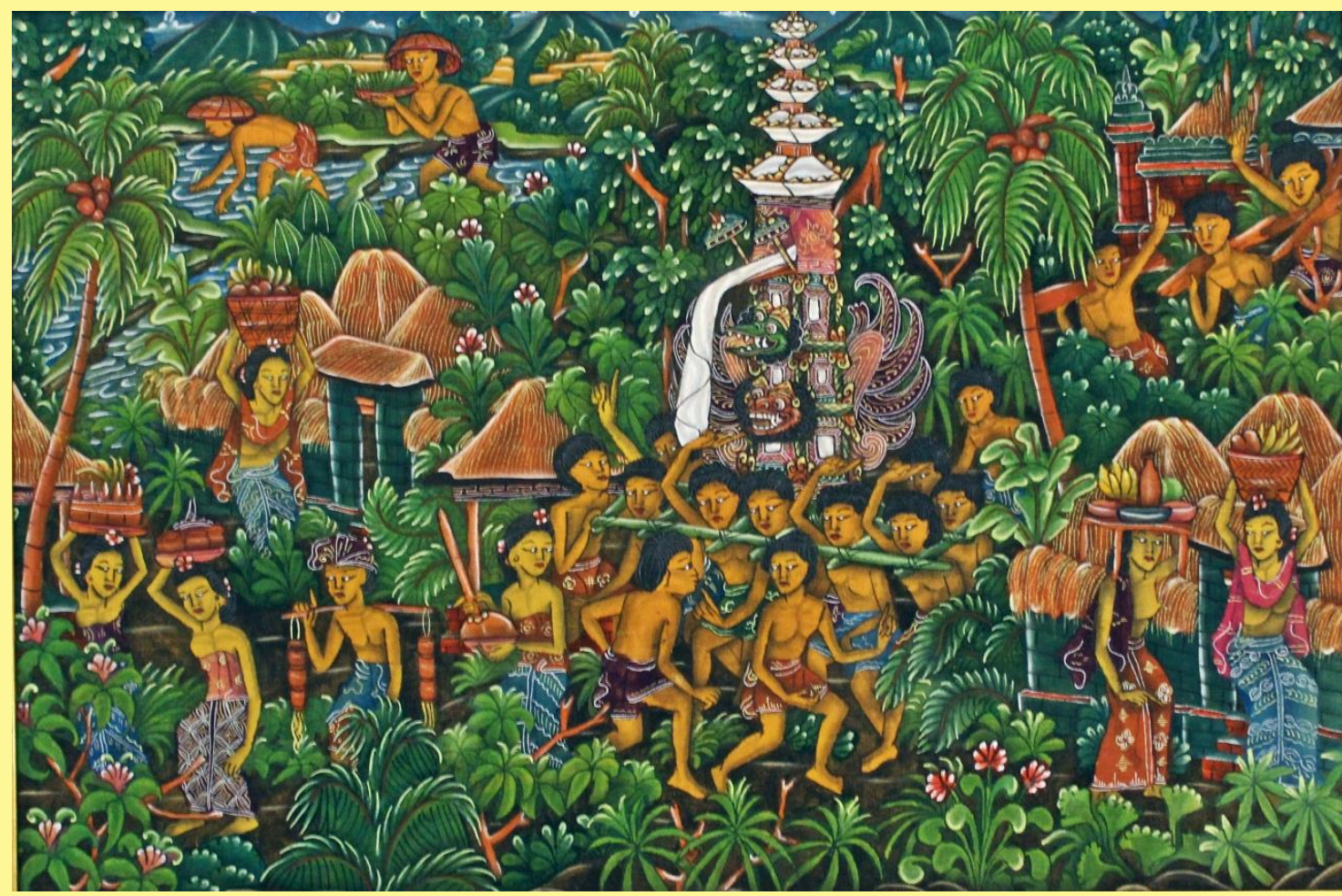

Pintura Sin título (escena aldeana y de cremación). Autor desconocido (Escuela de Batuan). C. 197o.Técnica mixta. Colección particular.

La llegada de visitantes extranjeros favoreció la evolución de la pintura, que dejó desde entonces de limitarse al ámbito religioso y adoptó también funciones decorativas y comerciales; a partir de entonces, diversas zonas de la isla cultivaron estilos distintivos, de entre los que sobresalen el estilo de Ubud, el del Batuan y el Sanur.

El primer foco en evolucionar sería el de Ubud, tradicional centro artístico y cortesano, y lo haría precisamente gracias a la presencia de artistas como Walter Spies y Rudolf Bonnet, que reordenarían la vida cultural de la región. Precisamente sería Spies el primero que animara a los artistas locales a profesionalizarse y a valorarse, fomentando la creación del Pitamaha (literalmente, "gran espíritu”), una cooperativa de artistas plásticos que tenía como objetivo preservar las tradiciones y controlar la calidad de las obras frente al avance del turismo. Gracias a las exposiciones del colectivo, que a veces recibía visitas de artistas extranjeros, el arte balinés comenzaría a ser conocido fuera de sus fronteras. Las novedades del estilo fueron de tipo temático y formal: se incluyó por primera vez la perspectiva, el uso de óleo y gouaches, y se realizaron escenas de la vida cotidiana, centradas en la vida aldeana, simplificando también la narración. Lo refinado del estilo haría que este se convirtiera pronto en el gusto oficial, aprobado y avalado por la nobleza. Pronto, Ubud entraría en franca competencia con otros núcleos artísticos. A Batuan llegaron 
también los nuevos materiales, y se representaron con un mismo tono abigarrado y oscuro escenas legendarias y de la vida cotidiana: tanto fue así, que uno de los mayores atractivos del estilo consistió en la rápida inclusión de elementos modernos (como aviones, coches o bicicletas) en las escenas balinesas. En Sanur, aldea de pescadores, se representarían por primera vez escenas marítimas, con un tono más desenfadado y decorativo ya que su principal mercado sería el turístico, ligado al artista belga Adrian-Jean Le Mayeur y a la tienda de los Neuhaus Brothers. La mayoría de las obras realizadas en Sanur tenía un tono estilizado y decorativo, y eran predominantemente en tinta negra, incluyendo escenas con animales salvajes o de temática erótica. Más adelante, otros movimientos revitalizarían la pintura balinesa tradicional, como la aparición de la miniatura Keliki, o, a partir de los 6o, el Young Artist Painting, auspiciado por el artista holandés Arie Smit.
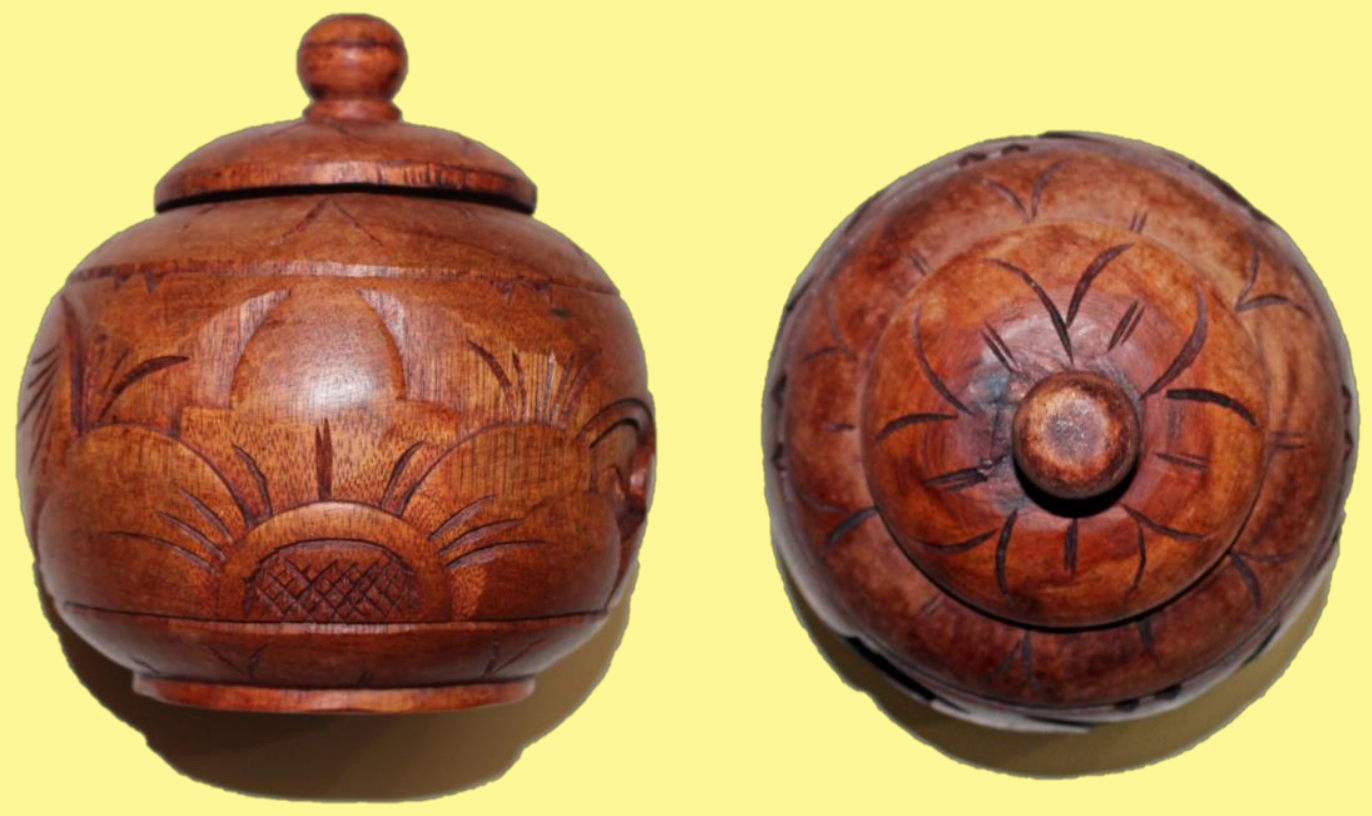

Caja de madera, tallada con estilo arquitectónico. S. XXI. Colección particular.
En cuanto a la escultura, la llegada del turismo también marcaría un antes y un después. Como en el caso de la pintura, la talla tenía un carácter elementalmente religioso, y estaba destinada a decorar templos y/o a representar dioses y guardianes en los mejores hogares. Realizándose tanto relieves como esculturas en bulto redondo, la mayoría de las escenas eran de tipo religioso, pero, dado que la mayoría de esculturas se realizan en una arenisca de muy mala calidad, esto dio pie a que incluso los templos incluyeran escenas modernas en sus renovaciones, con escenas de asaltos turistas, oficiales coloniales emborrachándose o, incluso, del artista Nieuwenkamp paseando en bicicleta. La escultura en madera sufriría una mayor evolución tras su contacto con el exterior, decantándose los nuevos artistas por el uso de líneas más depuradas y de maderas más nobles (en las que la región es excelente), desechando habitualmente la tradicional policromía.

Los balineses son, también, hábiles orfebres, aunque han concentrado sus esfuerzos en un objeto de gran trascendencia bélica y ritual como el kriss o keris, daga de hoja zigzagueante habitual en muchas regiones del sudeste asiático, pero que en Bali se decora con una profusión inaudita: su empuñadura (hulu) se diseña para que adopte la adopte la forma de un dios o un demonio, estando las piezas más 
lujosas forradas de oro y piedras preciosas. En muchos otros casos, algunos objetos que parecen de oro, como los tocados de las bailarinas o algunas marionetas, están realizados, en realidad, en piel de carabao, que después es pintada o recubierta de oro en los mejores casos.
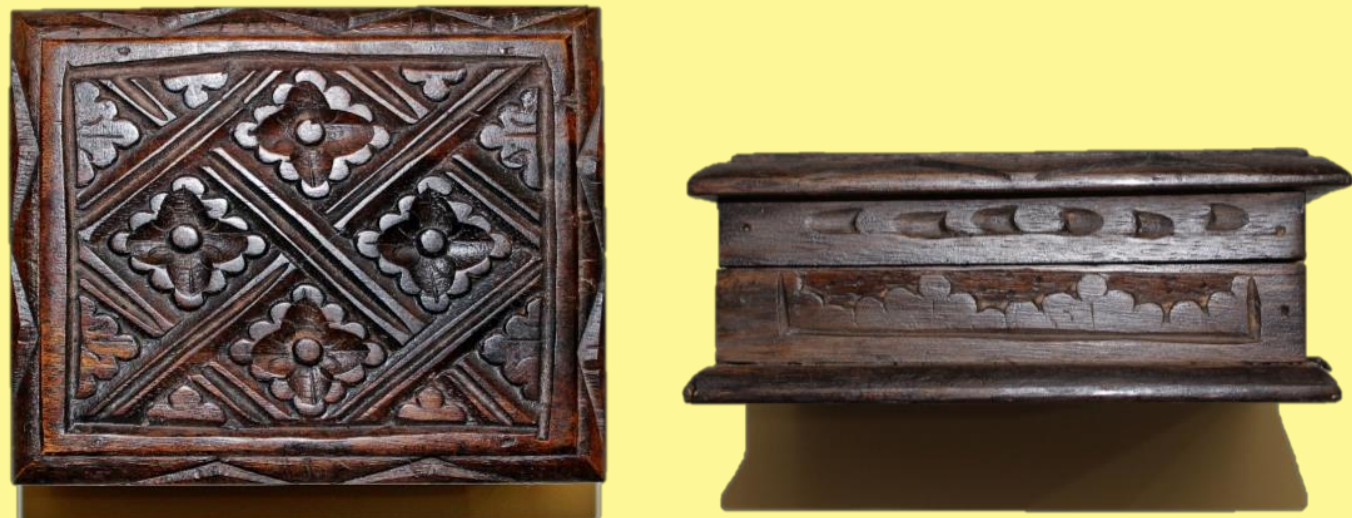

Caja de madera tallada. S. XXI. Colección particular.

Igualmente interesantes y coleccionados son los diferentes estilos textiles que adornan no solo la vestimenta cotidiana y ceremonial, sino que hoy se han extendido a todo tipo de objeto utilitario. La técnica más popular y extendida, aunque de origen javanés, es el batik, que consiste en el teñido parcial de las telas, dejando en negativo las zonas en las que se realizan dibujos mediante la aplicación de cera caliente. A la tradición balinesa pertenecerían, en cambio, tejidos como el ikat y el songket, o telas decoradas con oro como las prada, utilizadas en ocasiones especiales.

A la derecha, ejemplo de ikat doméstico de tipo decorativo. Lino y otros tejidos. S. XXI. Colección particular. En las págins siguientes, sarongs de batik con motivo de pájaros en varios colores (el primero, con imitación de prada),sarong con songket de imitación y sarong con motivos vegetales cortesanos. Textil. S. XXI. Colección particular.

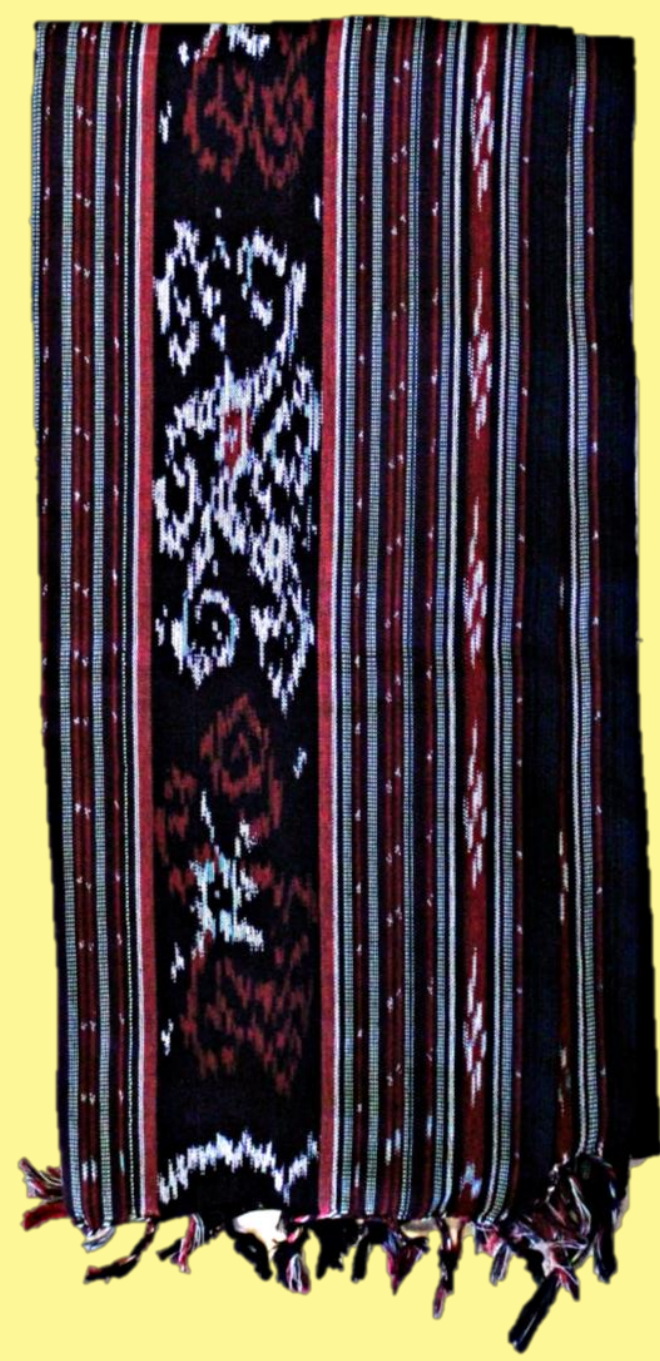



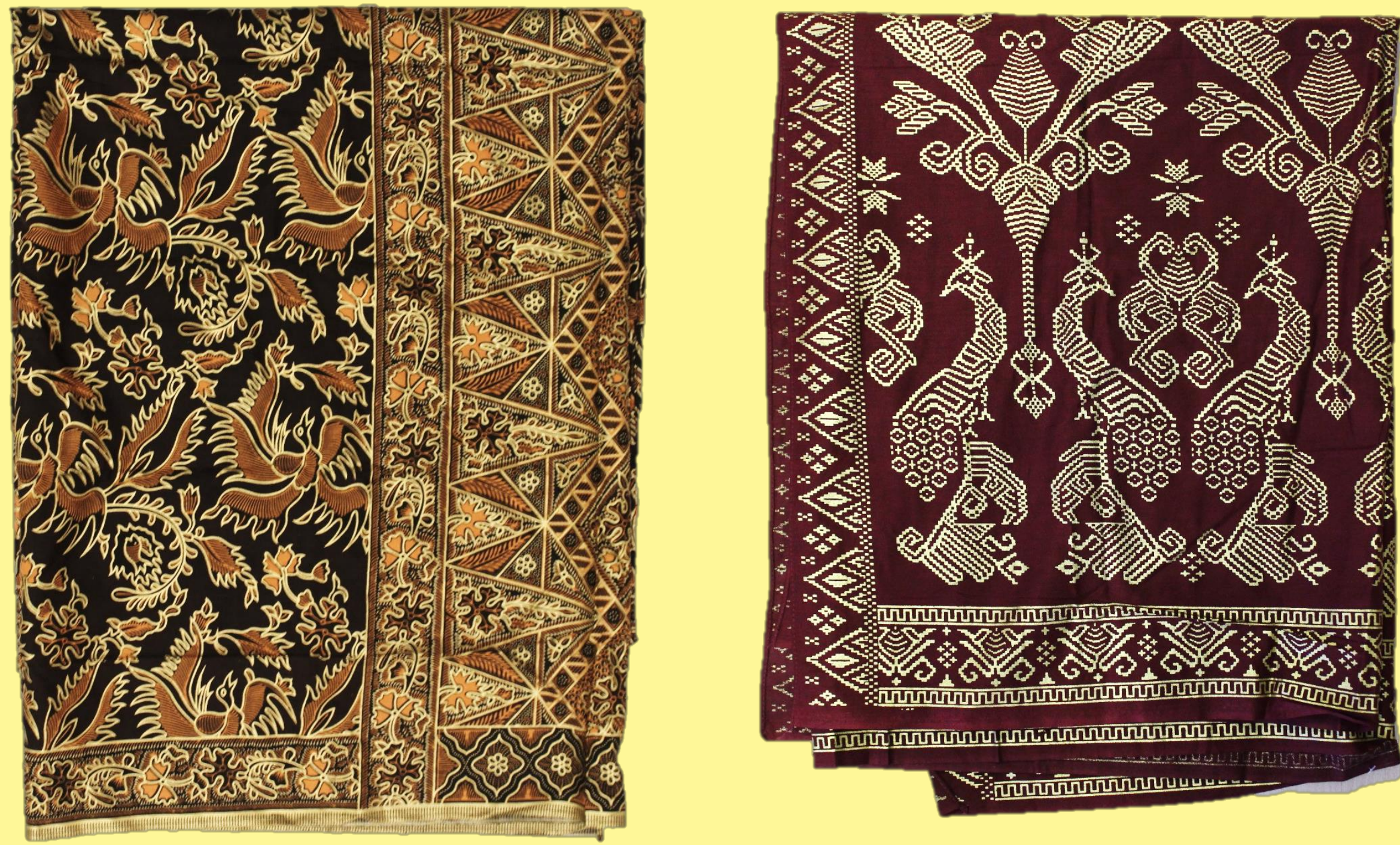

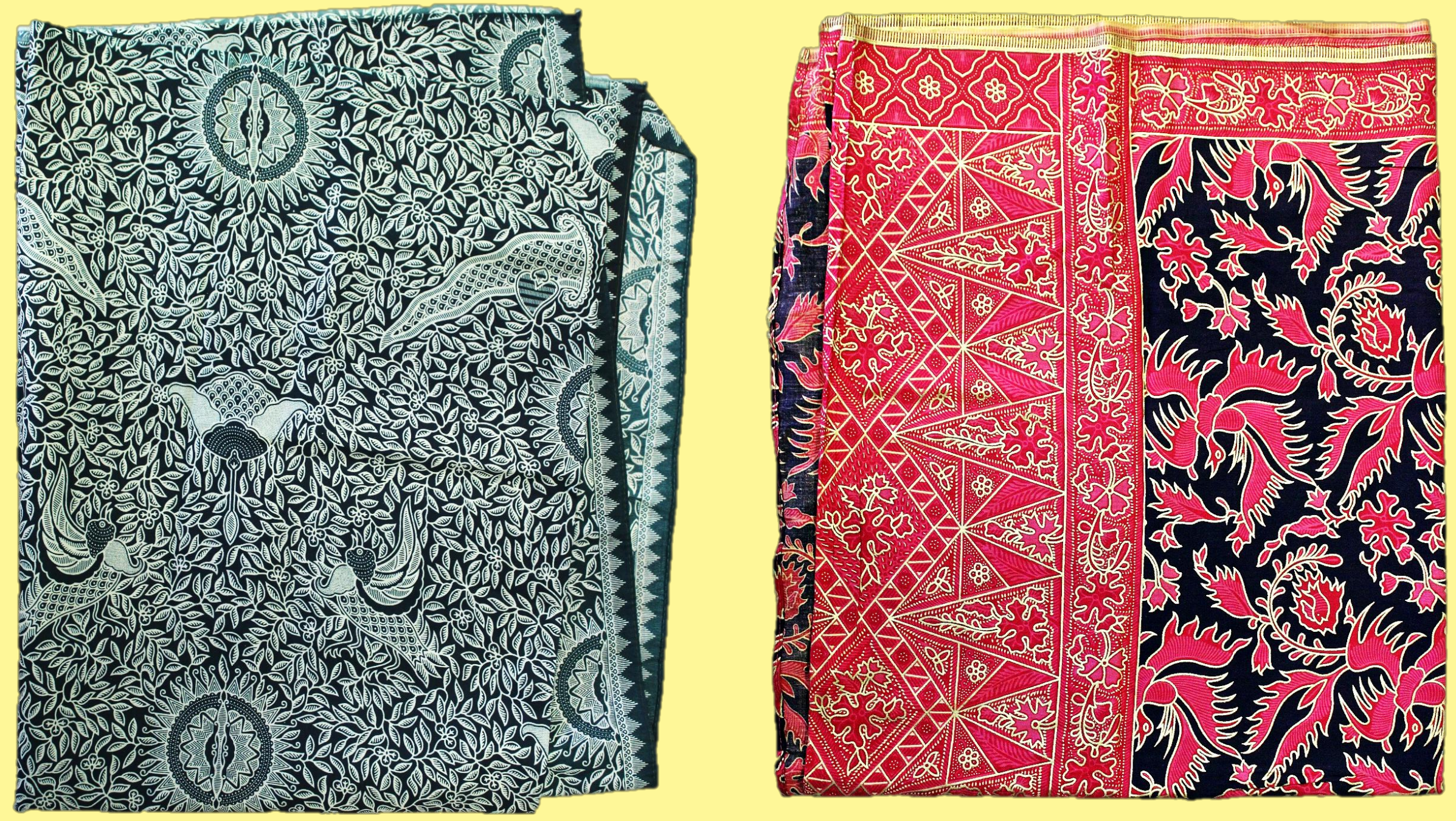


\section{LAS ARTES ESCÉNICAS EN BALI}

"Esta lección (....) en realidad, es fruto de un largo y paciente aprendizaje que ha de comenzar necesariamente en los primeros años. No solo los brazos y el torso han de moverse de modo perfectamente determinado, sino que la cabeza ha de balancearse en forma imposible de imitar si no se ha adquirido el hábito desde pequeño y los ojos han de moverse de un lado a otro en un momento debido; el abanico de la mano derecha ha de agitarse con arreglo a los cánones precisos, mientras los dedos de la otra mano adoptan las posiciones que vemos reproducidas en las estatuas de los templos hindúes. Y esto ha de realizarse con tan artificiosa naturalidad que nada parezca violento y todo resulte suave y gracioso.” - Julio Palacios (1935).

Aquel que quiera disfrutar de las espectaculares artes escénicas de la isla debe tener en cuenta que, con la salvedad de alguna manifestación moderna y orientada al turismo, estas están profundamente vinculadas al ámbito religioso. Además de danzas exclusivamente religiosas, como los sanghyang (en el que las jóvenes bailarinas entran en trance) o los pendet (destinados a realizar ofrendas), gran mayoría de las representaciones de danza se realizaban en templos y con alguna intención religiosa. A pesar de esto, fueron, y son, uno de los principales atractivos de la cultura balinesa, incesantemente retratados en pinturas, fotografías y películas.

También durante esa época debió llegar el gamelán, forma tradicional de orquesta en Java y Bali. Formada por diversos instrumentos, se cree que fue durante esta época cuando los diferentes tipos de metalófonos, como el pemadé que aquí se expone, adoptaron su forma actual. De hecho, gamelán es una palabra javanesa (la versión balinesa sería gambelán) que deriva de gamel, nombre que reciben los mazos con los que se golpean los metalófonos. Diferentes regiones (Java, Bali, Sunda, Madura...) tienen diferentes versiones de gamelán, pero esta forma de orquesta se considera que es una creación autóctona de la región. 


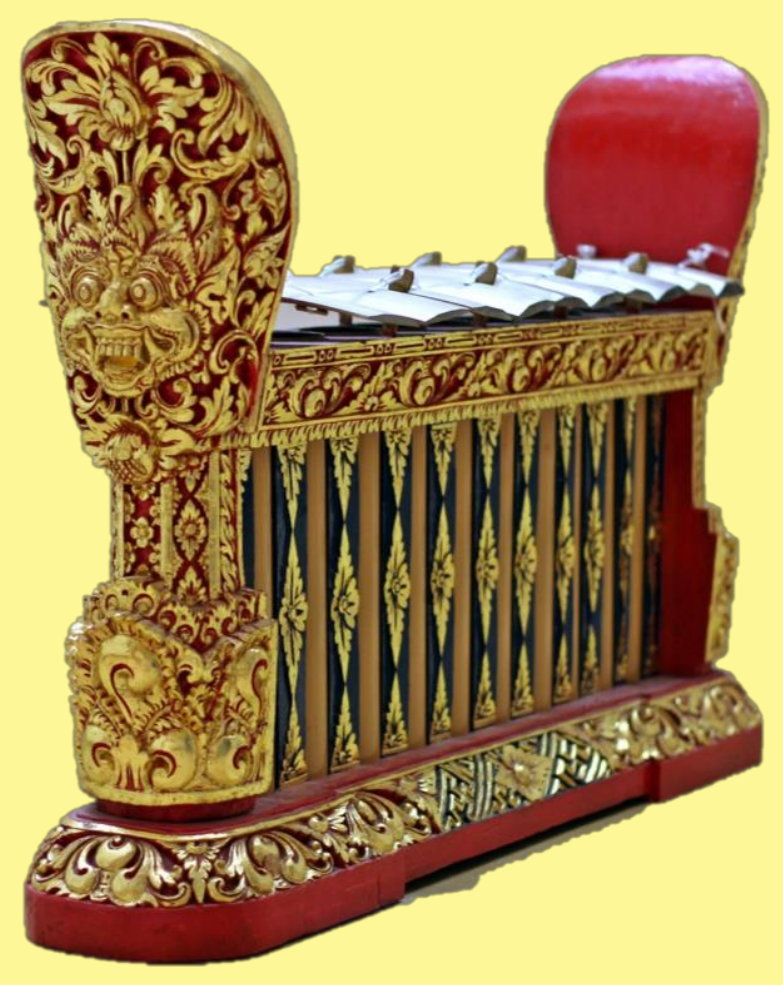

Según los javaneses, el gamelán fue un invento del dios Sang Hyang Guru, que según la tradición gobernó Java en el 230: dado que necesitaba poder llamar y convocar a los dioses, inventó el gong, pero para poder emitir mensajes más complejos le agregó otros instrumentos, creando así el gamelán. Aunque seguramente los metalófonos no se agregaron a la orquesta en Java hasta el s. XII, estas orquestas estuvieron desde un principio -y todavía hoy- asociadas a un uso ceremonial, ya sea de carácter religioso, cortesano o de ocio (elementos que suelen ir unidos). El gamelán balinés tiene muchas diferencias con los de otras regiones: entre ellas, destaca el uso de un tempo más rápido, los instrumentos se construyen por parejas, y los instrumentos se mantienen siempre juntos, en el balé (espacio elevado, cubierto y abierto) en el que también se tocan, ya pertenezcan a un templo, palacio o a la comunidad (banjar); en el caso de pertenecer a una comunidad, se considera que los instrumentos pertenecen al conjunto de la misma, y el balé banjar ocupa un lugar principal en la aldea. Aunque tradicionalmente no se escribían los temas, a partir del siglo XIX algunos palacios javaneses comenzaron a 
registrar algunos temas para favorecer su preservación: durante el periodo de entreguerras, Colin McPhee registró y "reinterpretó" muchas de las composiciones balinesas, lo que ha permitido conservarlas.

En Bali tienen lugar una gran variedad de formas de teatro, danza y música (el canto no es $\tan$ habitual), que a menudo se realizan de forma conjunta. Uno de los mejores ejemplos de arte total es la arja, llamada por los extranjeros "ópera balinesa", considerada uno de los ejemplos más refinados. Sin duda, la historia más popular, más llamativa y representativa es el Tjalong Arang, en la que aparecen los populares personajes de Rangda (una bruja de época del rey Erlangga, y en algunas versiones, su propia madre) y Barong (un león protector, manejado por varios actores), que representan, respectivamente, las fuerzas del mal y del bien. La ya centenaria obra, que combina a la perfección actuación, música y danza, reúne elementos refinados de la tradición cortesana javanesa de época Mahapajit con otros pertenecientes a la "brujería" balinesa y una pantomima fácilmente entendible, por lo que resulta del agrado de turistas y balineses por igual.

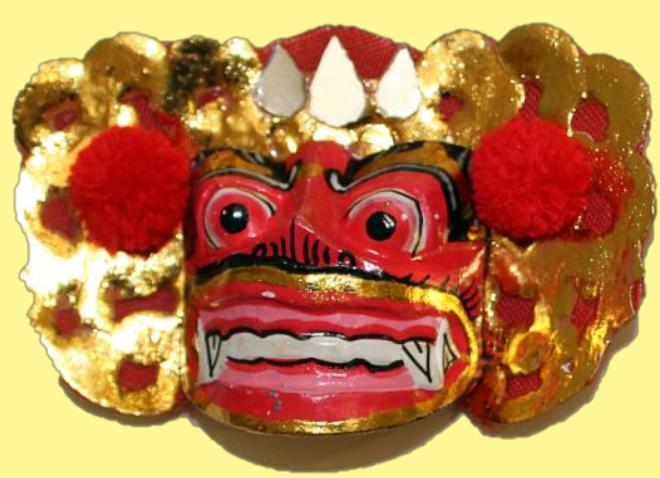

Máscara decorativa con motivos de Barong, de carácter turístico. Técnica mixta. S. XXI. Colección particular.
Fue el baile lo que más atrajo a los visitantes extranjeros en Bali. Seguramente influyera el que la gran mayoría de los bailes están realizados por mujeres (con la excepción de algunas danzas bélicas masculinas, como el baris, o el neotradicional kecak, creado durante el periodo de entreguerras y que imita el canto de un grupo de monos), que tradicionalmente eran vírgenes y de corta edad -pues se las consideraba más ágiles-, que no solo se movían con gracia y delicadeza, sino que aparecían delicadamente ataviadas con telas y accesorios de todo tipo dorados y de colores vibrantes.

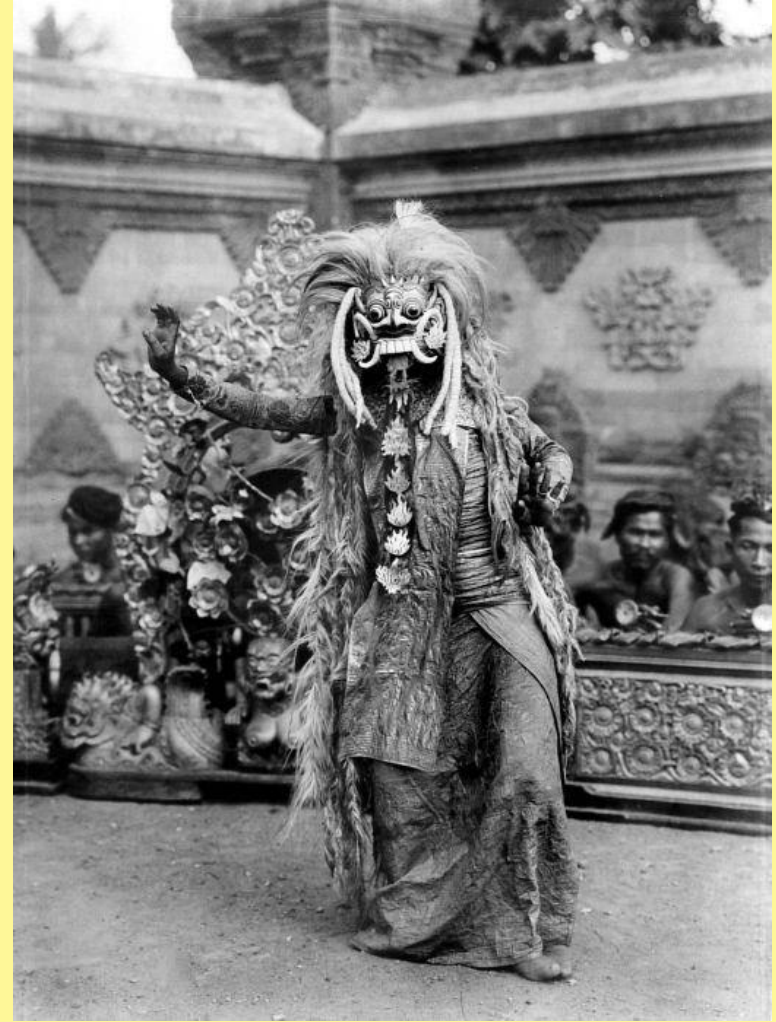

Rangda, personaje protagonista del Tjalon Arang (1929). Fotografía de COLLECTIE TROPENMUSEUM, $n^{\circ} 10004670$.

El más famoso de los estilos de baile sería el regio legong, aunque también era muy admirado el cendrawasih, en el que la bailarina 


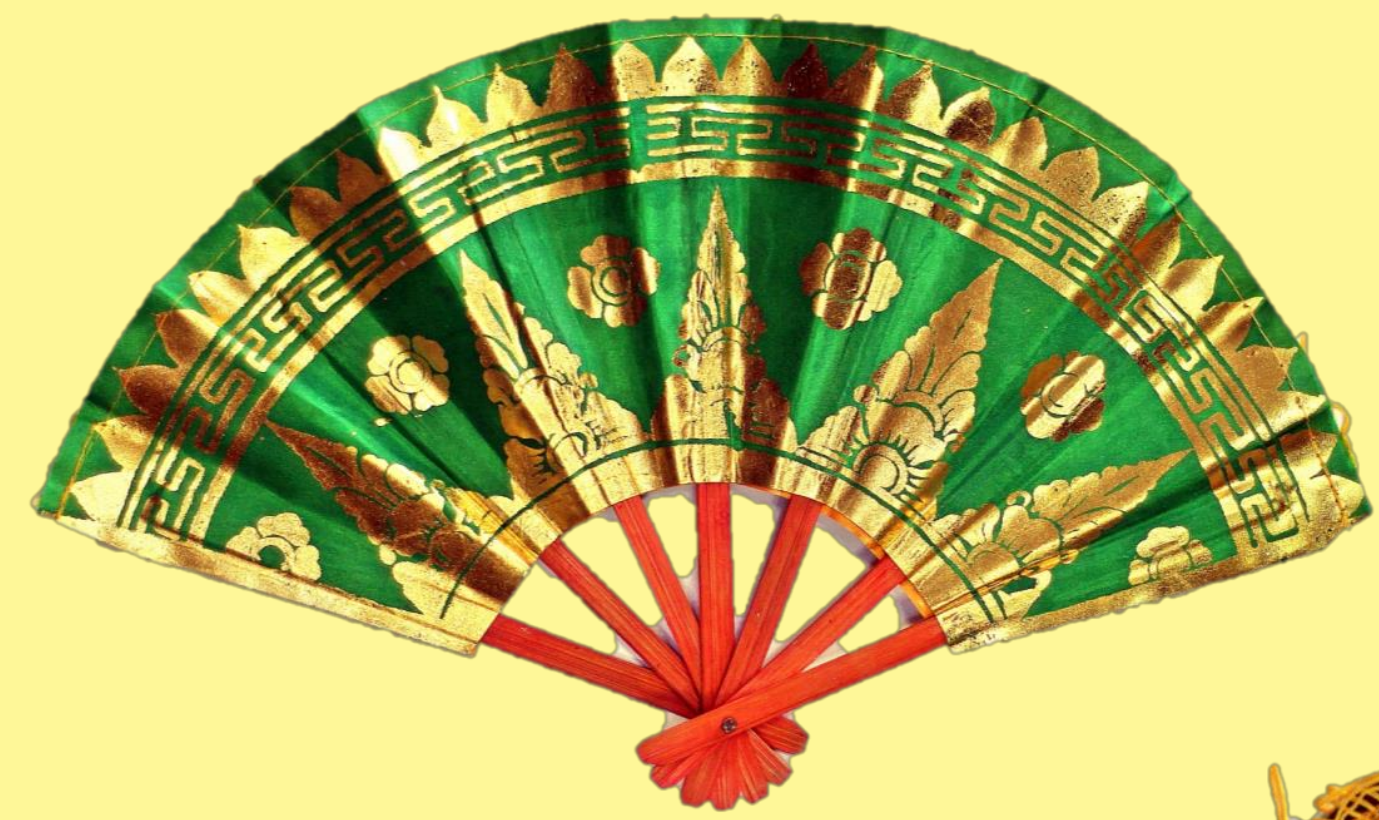

el wayang klitik, con formas similares, pero con marionetas de madera (la palabra klitik es una onomatopeya del sonido que producen) y el wayang golek, con marionetas tridimensionales realizadas en madera y lujosamente vestidas. En los tres casos, las historias narradas suelen ser parecidas: a las historias clásicas del Hinduismo, tomadas del Ramayana (que suelen ser conocidas como Ramasinta, manera local de llamar a la pareja protagonista -Rama y Sita-) y del Mahabharata (especialmente, las historias de Arjuna y los pandawas) se unen a veces nuevos

imita los movimientos del ave del paraíso. Hoy en día, las bailarinas ya no suelen ser tan jóvenes, aunque las mujeres interpretan, a menudo, muchos de los personajes masculinos. Todavía hoy, el aprendizaje de ciertas danzas se considera obligado en escuelas e institutos y está incluido dentro del currículum escolar.

Tanto o más popular que el teatro con actores (wayang orang, en el que destaca el topeng, con actores enmascarados), es el teatro con marionetas, de diversas clases: el wayang kulit, teatro de sombras con marionetas articuladas realizadas en piel de carabao, Abanicos estilo legong (souvenir). Madera y textil policromado. S. XXI. Colección particular.

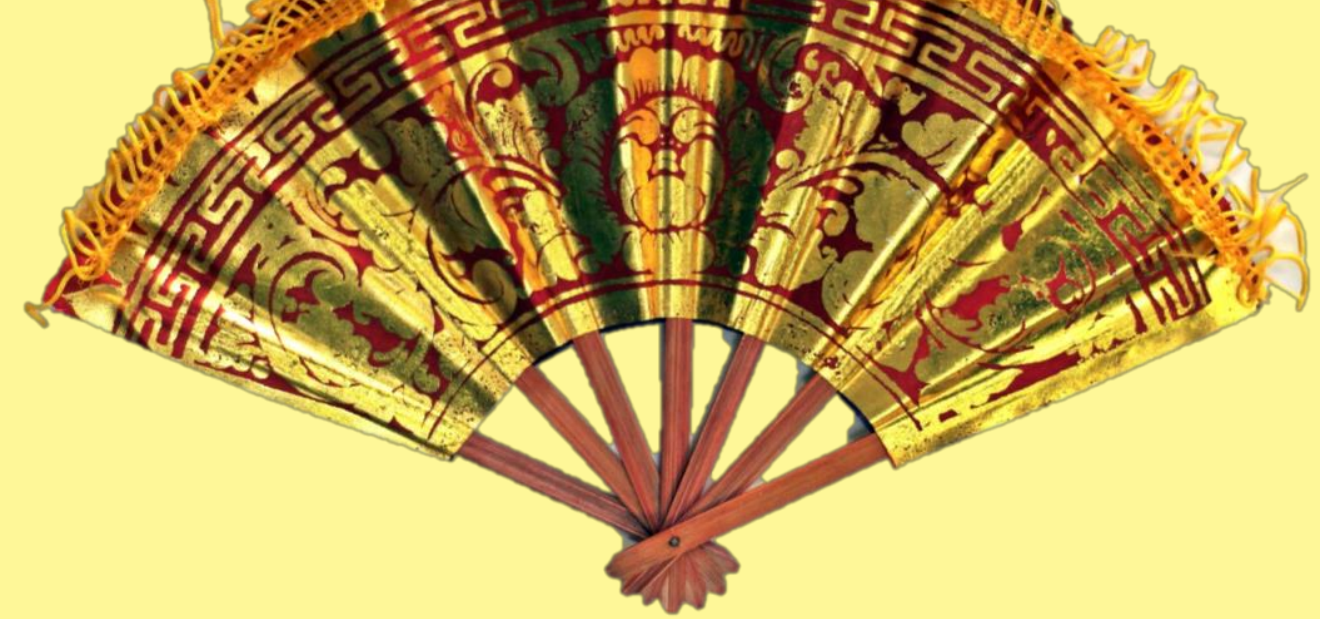




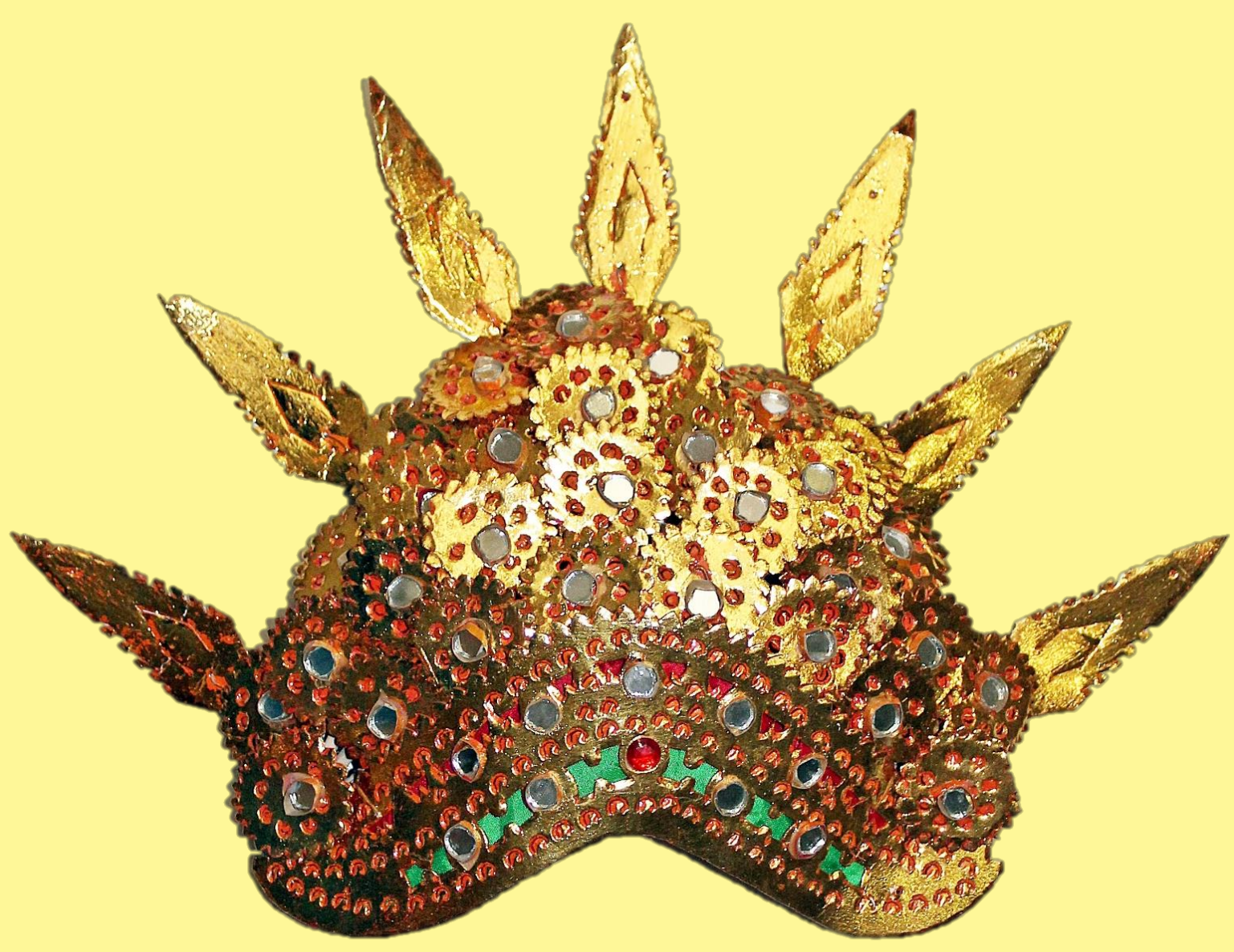

personajes como criados, que, al estar desposeídos de ningún carácter sacro, pueden lanzar todo tipo de chistes e improperios al público, aportando así un tono cómico y crítico a los espectáculos. La mayoría de representaciones de marionetas se llevaban a cabo durante la noche, a la luz de las velas, que servían para provocar las sombras (wayang) que dan nombre al teatro, cuando el dalang (narrador) recitaba la historia y manejaba las marionetas. Al contrario de lo que sucede en otros teatros de sombras, en el caso balinés el público se sienta a ambos lados de la pantalla, por lo que las marionetas suelen estar más y mejor decoradas que en otros lugares de Indonesia.

Tocado para danza legong. Piel de carabao, madera, metal, plástico y textil. S. XXI. Colección particular.

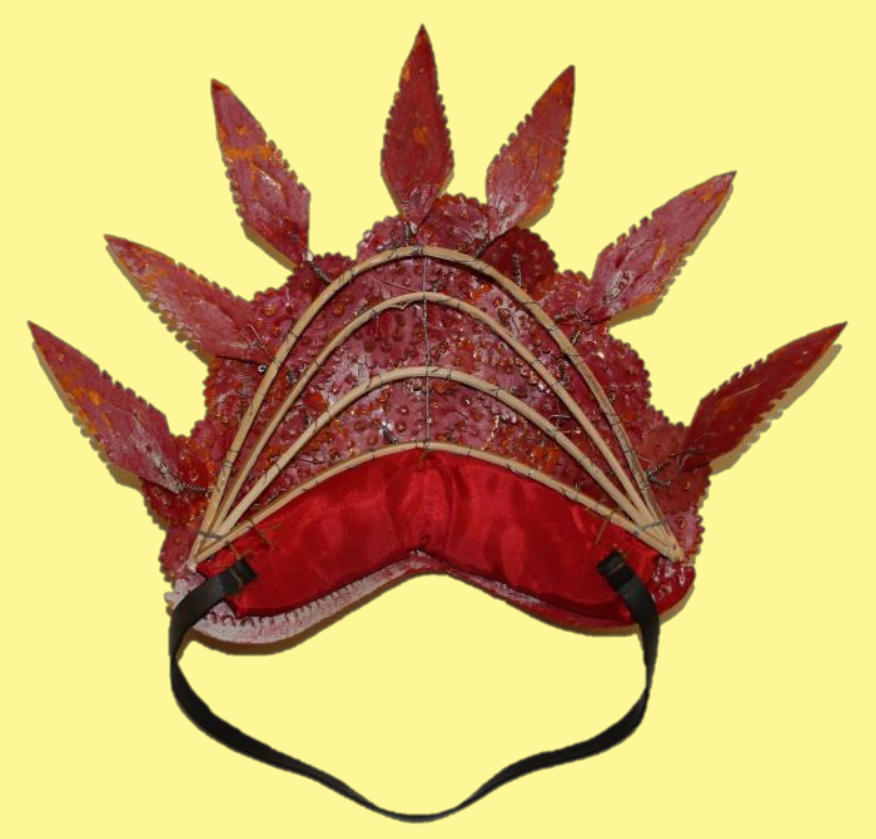




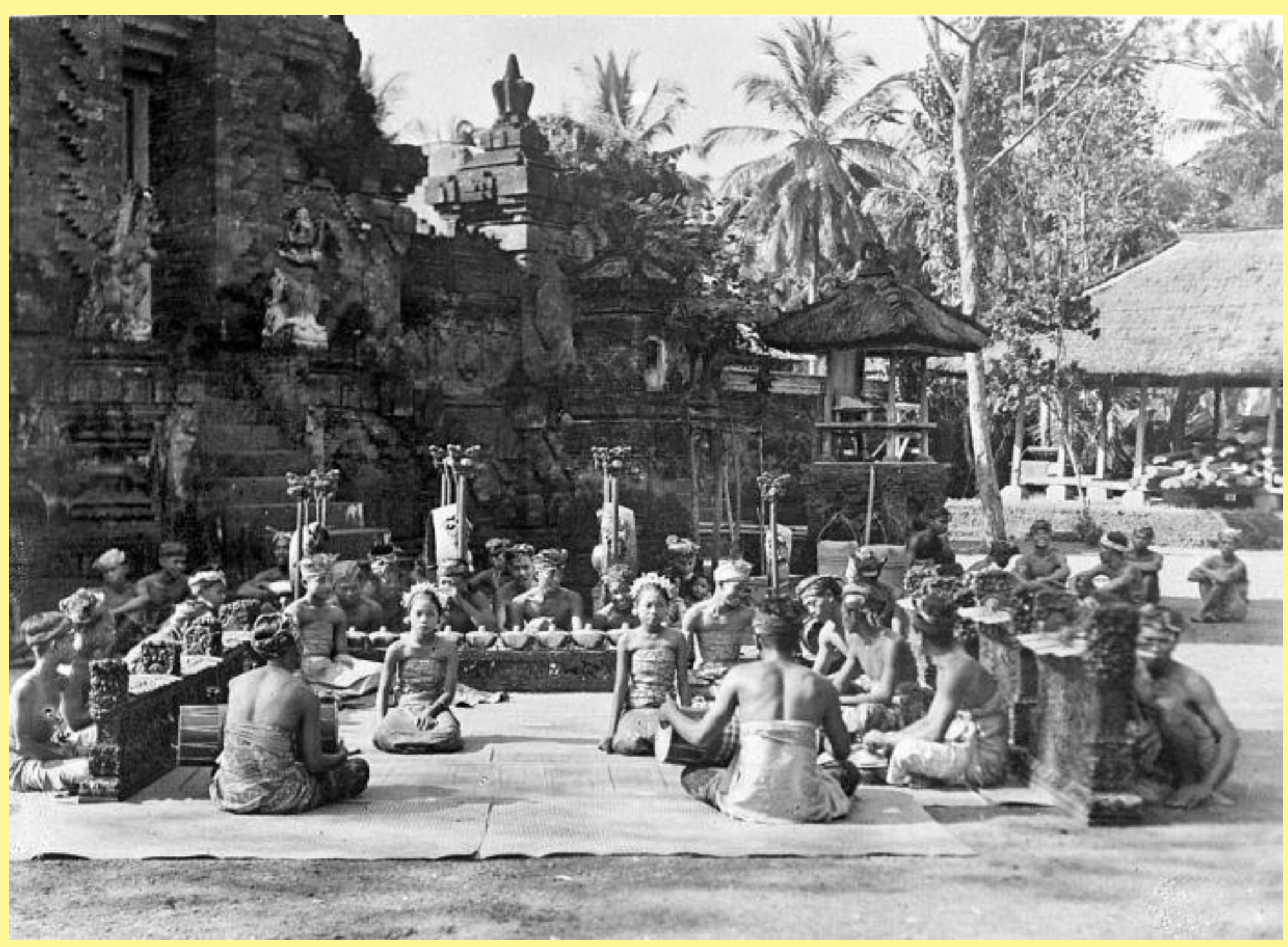

Bailarinas balinesas en una actuación en un templo, frente actuación en un templo, frente Fotografía de COLLECTIE TROPENMUSEUM, 10004669 


\section{LA GASTRONOMÍA BALINESA}

"Para el paladar occidental no es fácil acostumbrarse a la comida balinesa. Además de que siempre se sirve fría, se considera incomible a menos que esté intensamente sazonada (...) Picaba tanto, que incluso yo, un mexicano acostumbrado a comer chile, lloraba y sudaba" - Miguel Covarrubias (1937).

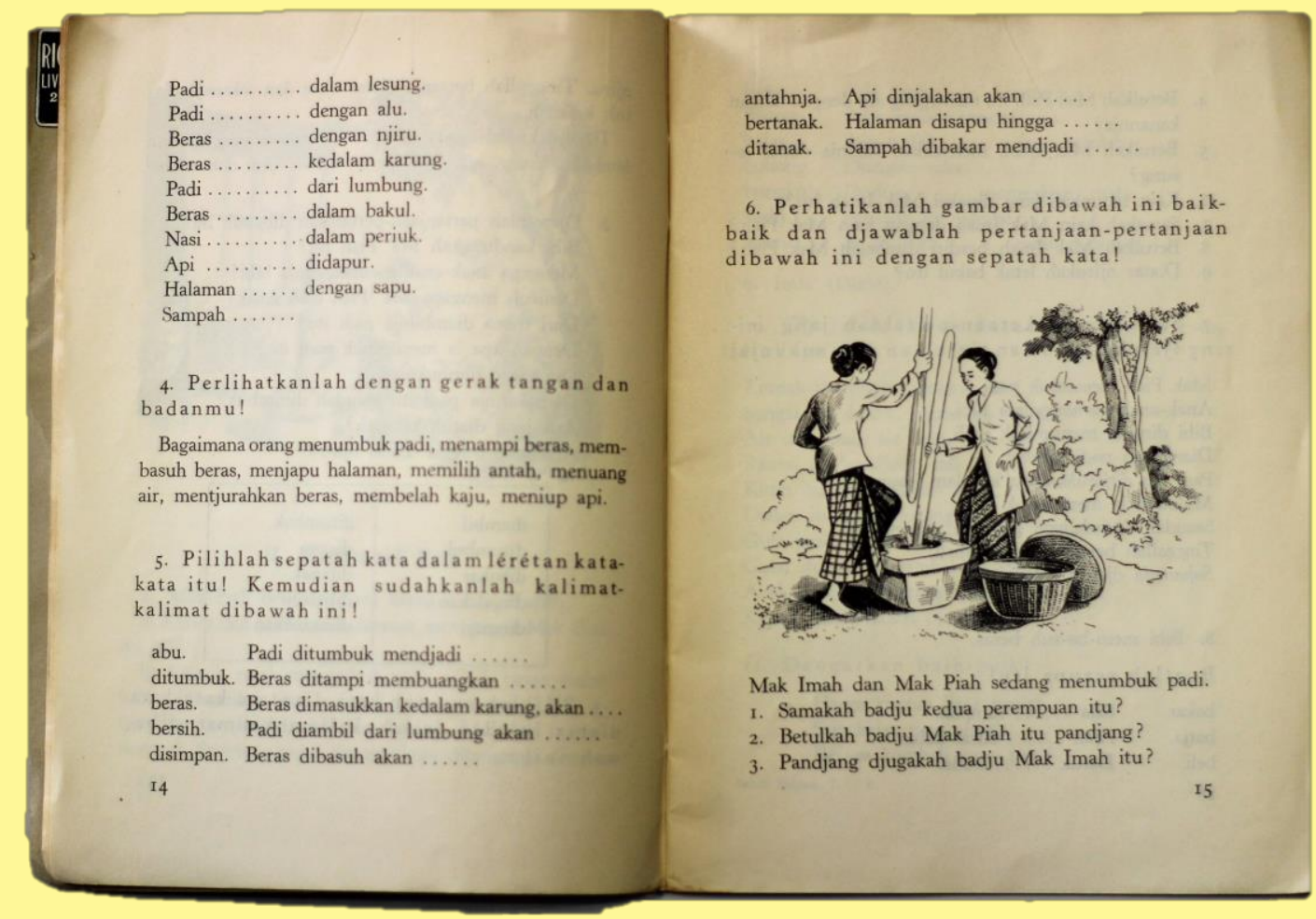

Sendi Bahasa: peladjaran Bahasa Indonesia bagi sekolah rendah (R. Soekardi, Yakarta, J.B. Wolters, 195o). Colección de la Biblioteca de la Universidad de Zaragoza.
La gastronomía balinesa fue uno de los elementos que más sorprendió -y sorprende- a los visitantes extranjeros; tanto es así, que ya autores como Covarrubias o Yates no dudaron en dedicar capítulos de los libros a estos temas, en los que incluso incluyeron detalladas recetas. A pesar de ello, lo cierto es que, como en muchos otros lugares del sudeste asiático, en Bali existe una gran tradición de comida callejera, tanto entre lugareños como visitantes.

Puesto que el arroz es la base de la vida en Bali, también lo es de su gastronomía, y se ingiere en cualquier momento del día, bien como plato principal o como acompañante. De hecho, la palabra nasi ("arroz") sirve para el mismo concepto de "comida", ya que lo raro es que no aparezca. Este puede servirse hervido y blanco y como acompañante, o frito en toda una variedad de platos, de los que el más habitual es el nasi goreng. Desde la década de los 6o, los fideos de trigo (mie), frescos o instantáneos, se han ido introduciendo progresivamente en la dieta, y son un sustituto económico que permite enriquecer las comidas diarias. Una gran cantidad de sabores intensos contrarresta la neutralidad del arroz blanco: se usa la cúrcuma, la pimienta, chiles y varias especias picantes, pero también abunda el uso de ajo y cebolla, la pasta de pescado, la lima y el coco rallado. 


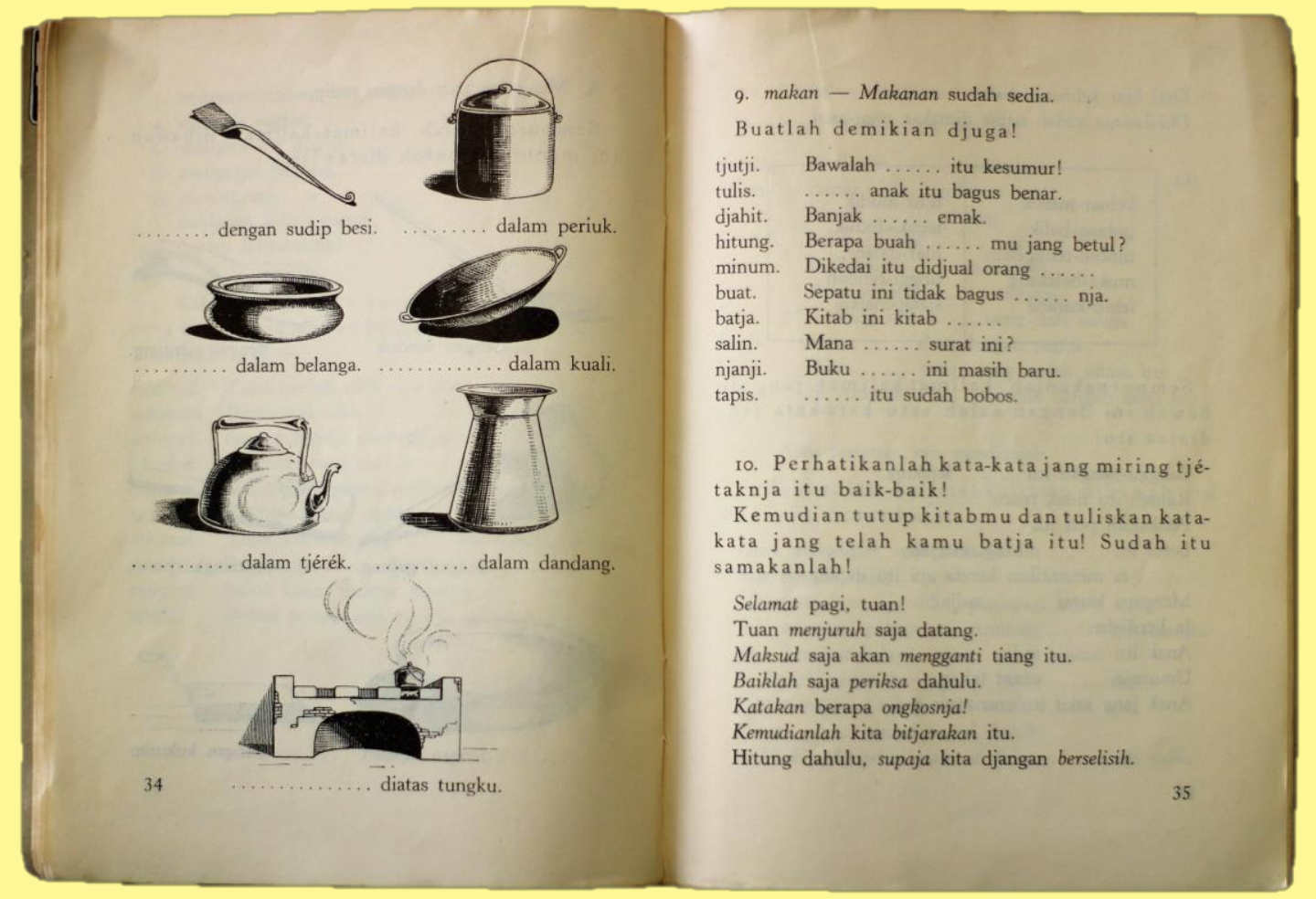

Sendi Bahasa: peladjaran Bahasa Indonesia bagi sekolah rendah (R. Soekardi, Yakarta, J.B. Wolters, 195o). Colección de la Biblioteca de la Universidad de Zaragoza.

Existen pocos tabúes, aunque, tradicionalmente, algunas castas tenían ciertas prohibiciones: los sacerdotes no comían cerdo, ni bebían alcohol (de la misma manera que los escasos musulmanes de la isla) ni podían comer en calles o mercados, y la nobleza superior tenía oficialmente prohibida la carne de res. También muy llamativa para los occidentales resulta que la tradicional forma de servir la comida o portarla consigo: dispuesta o envuelta sobre grandes hojas de plátano, que a veces hacen la parte de decoración.
Frutas, verduras y hortalizas completan la base de la dieta: al arroz se unen el maíz, diversos tubérculos, berenjenas, soja, cacahuetes, tamarindo y una grande y variada cantidad de frutas: algunas, como los plátanos, cocos, papayas o sandías son ahora habituales en nuestras mesas, pero el fruto del árbol del pan, la pitahaya, el rambután, el mangostán, la fruta serpiente (salak) o el oloroso durian seducen y asustan a partes iguales. Estas se ingieren de todas las maneras posibles, especialmente en coco, del que se aprovecha todo (pulpa, agua, aceite...).

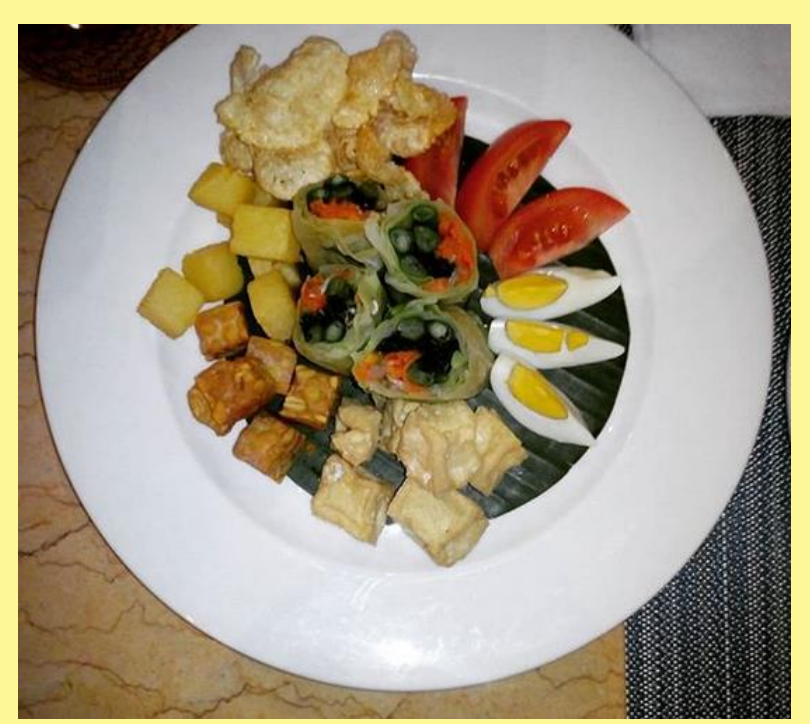

Gado-gado sin mezclar y sin salsa. 
Cada vez se ingiere más carne, siendo el pollo, el pato (barato y útil para el cultivo de arrozal) y el cerdo las más habituales (aunque el cochinillo a la brasa es uno de los platos más complejos y caros); más raros y caros son la vaca o el carabao. Otras delicatessen, hoy prohibidas, eran la carne de pangolín, murciélago, puercoespín y, sobre todo, de tortuga marina. Tampoco era infrecuente la ingesta de jabalíes, lagartijas, calamares, cangrejos e insectos (especialmente, de libélulas y grillos), pero el pescado y el marisco en gran cantidad es un añadido reciente, consecuencia de las mejoras en la pesca; el más habitual suele ser el pez limón, o unas pequeñas langostas de caparazón verde.

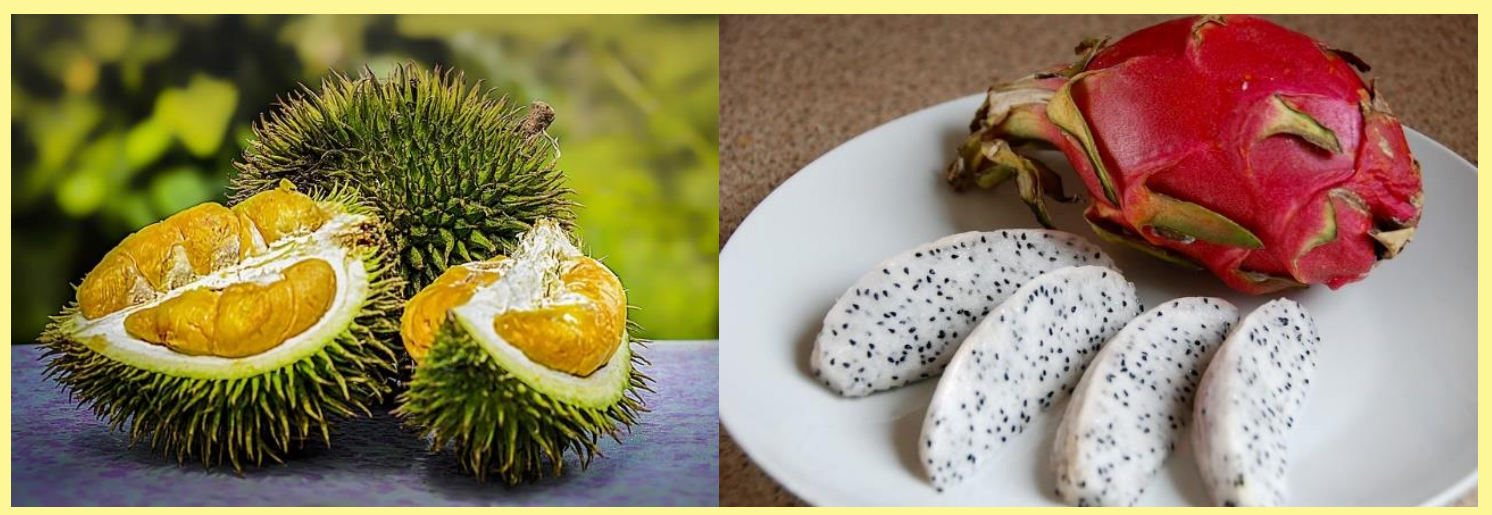

El durian y la pitahaya o fruta dragón son algunos de los elementos más característicos de la isla.

La mayoría de carnes se preparan fuertemente condimentadas, y se cocinan al carbón, excepto cuando se toman salteadas o en sopas. Las preparaciones más habituales con el saté y el lawar, que se hacen con casi todo tipo de platos. El condimento más habitual y típicamente balinés es el sambal, realizado a base de varios chiles picantes, chalotas, e ingredientes que varían como aceite de coco, jengibre, lima y hierba limón.

Hoy en día, las cervezas y cócteles compiten contra licores y preparados locales y el café (del que existen numerosas plantaciones en la isla, especialmente de kopi luwak o "café de civeta", uno de los más caros del mundo) ha ido desplazando al té en el consumo diario, de la misma manera que han cambiado los platos principales, o solo por influjo de Occidente sino por la propia gastronomía indonesia. Así pues, hoy es fácil poder disfrutar de unos socorridos nasi goreng o mie goreng (arroz o fideos salteados con diferentes verduras $\mathrm{y} / \mathrm{o}$ carnes), de un tradicional gado-gado (literalmente "mezclamezcla", una especie de ensalada o plato frío con multitud de ingredientes vegetales), o si, queremos disfrutar de un opíparo manjar, podemos emular a los colonos holandeses y ordenar un rijjsttafel (lit. "mesa de arroz"), que contendrá como mínimo una docena de pequeños platos de todo tipo.

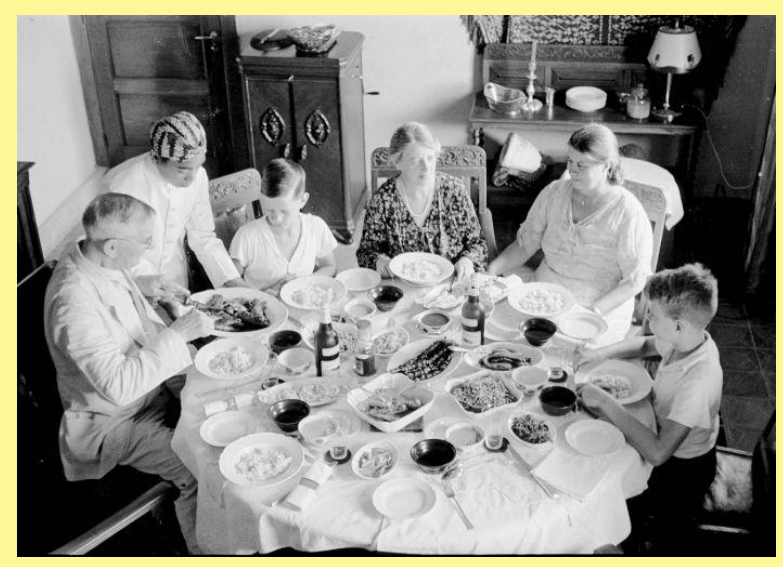

Rijsttafel en una casa colonial holandesa de Bandung (1936), COLLECTIE TROPENMUSEUM $n^{a} 10030167$. 


\section{LAS DANZAS RITUALES EN LA ISLA DE BALI}

\section{Por Ricardo Martorell y Téllez-Girón ${ }^{12}$}

Bali es la hermana menor de la riquísima Java. Todo parece vivir en aquella isla paradisiaca con la fragancia de la pubescencia. Pubertad que sin faltarle la lozanía, su tesoro, encierra los encantos de una juventud en sazón. Pubescencia de los trópicos.

Los balineses -malayos de raza- conservan su civilización de abolengo hindú, con una ejecutoria limpia de injerencias o invasiones extrañas. La avalancha musulmana que en los siglos XV y XVI se adueñó de la expresión geográfica llamada Malasia, haciendo suyas hasta las islas más meridionales del archipiélago filipino, respetó la isla de Bali. Quiero suponer que, como consecuencia de esta exención, sus habitantes no parecen empequeñecidos moralmente al faltarles la libertad de acción de la raza malaya, nacida para correr las aventuras de piraterías; donde el triunfo sin veleidades -como hijo de la fortuna que era- jamás se separaba de los caudillos bravíos de los mares de aquellos confines.

Acaso también por la misma razón, los balineses son, entre todos los pueblos malayos, los más perfectos físicamente. Las mujeres, menudas, con el claroscuro de un bronceado tibio en su piel; al aire todas las curvas y redondeces de su torso, allí, donde los colonizadores dejaron a aquellas gentes «vivir su vida» de paradisíaca e inocente desvergüenza; gráciles y elegantes sus movimientos de danzarinas nonatas; sus ojos de fuego y brillantes, «suave a la vista» sus cabellos. Ellos, de estatura más elevada, son para nosotros hombres de talla media, musculosos, al parecer con una fortaleza de gentes sanas.

El Tjinegara, un paquebot holandés, nos llevó desde Manila -la «perla de Oriente»- hasta Boeleleng, el puerto de Bali. Éramos hasta una treintena de turistas, que no nos habíamos visto

${ }_{12}$ Debido a su gran interés y sorprendente actualidad, reproducimos aquí el capítulo que el desconocido historiador Ricardo Martorell y Téllez-Girón escribió sobre Bali en su libro Trece crónicas de viaje por China, Mongolia, Japón, Filipinas, Bali, Siam y la India (1933). Dado el pronto fallecimiento del autor, su obra ha quedado sin estudiar y sin antes de hallarnos sobre las cubiertas de la motonave holandesa; terminada nuestra visita a la isla, haríamos juntos probablemente la travesía a Sourabaya, y ya en Java, nos desperdigaríamos en distintos grupos para no encontrar a los demás, sino accidentalmente, en la visita de tales ruinas o cuales plantaciones modelos, que hacen de la rica colonia de los Países Bajos un emporio de riqueza.

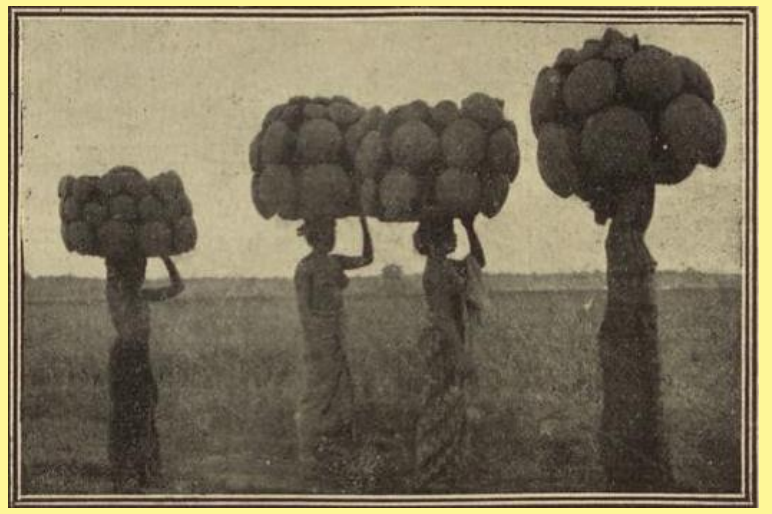

El turismo es un azote moral que, en forma de torrente de oro, padece la hermosa isla. Los extranjeros -americanos en su mayor parteestán haciendo interesado y pedigüeño al indígena: con sus dádi-vas desmoralizan desde el vendedor ambulante a las bailarinas, que ofician ante el templo como servicio divino ofrendado a los dioses; cotizando por unas monedas el dejarse

reeditar. Sirva este capítulo para comenzar a recuperar su reeditar. Sirva este capitulo para comenzar a recuperar su memoria. Por respeto al autor, mantenemos las palabras balinesas escritas según la transcripción holandesa (hoy 
examinar de cerca por los viajeros, antes o después de la ceremonia; hasta para dejarse retratar con sus galas y remedar ante el aparato la pirueta ritual, presentan luego la mano solicitando la recompensa.

-Dos años tan sólo -me decía un cretense, nacionalizado balines que añora los días, cercanos aún, de la existencia placentera y simple de la isla, antes de ser explotada por sus colonizadores como presa del gran turismo - han bastado para transformar a estas gentes. La divina imprevisión de un pueblo que no conoce las privaciones, se torna ahora en avaricia por conseguir dinero. $\mathrm{Y}$ puede usted creerme: cuando estos pueblos sencillos se dan cuenta del valor del dinero, pierden todas sus virtudes. Después de veinticinco años de gozar de las delicias de Bali, tendré que abandonarla para no terminar por odiar este Paraíso. Los pasajeros del Tjinegara, que desembarcamos en Boeleleng, divididos en dos grupos, recorreríamos la isla: unos, en una dirección; otros, siguiendo rumbo opuesto; pero no haríamos visitas «en manada», capitaneados por un guía -siempre he odiado esas excursiones colectivas-. En automóviles, sin formar siquiera caravanas, recorreríamos el circuito turístico; de esta manera, cada uno podría detenerse según sus aficiones, prescindiendo, si no le interesaban, de números que figuraban en el programa; compensándose, en cambio, haciendo parar el automóvil a cada instante para admirar mejor las perspectivas del paisaje tropical, el tipismo de las aldeas de la montaña, o para calmar la sed con el agua blanquecina y fresca de los cocoteros, como una horchata natural.

Yo hacía las etapas en unión de una muchacha americana, de veintitrés años, que daba la vuelta al mundo sin echar de menos acompañantes que la solucionaran las pequeñas molestias y problemas de los grandes viajes; y sin embargo, la expresión ingenua de sus ojos verdes de jade y la perfecta feminidad de su carácter, no harían presumir en ella la decisión y voluntad precisas para emprender y llevar a feliz término su propósito.

iQué atardeceres aquellos de Bail! En el refugio de Kintamani, las brumas vespertinas velaban los gigantes de la isla, antiguos volcanes; a Poniente, con el resplandor rojo, en llamas las nubes que apagaban lentamente aquel incendio, los picos de Tjatoer y Bratan; a Oriente, en la penumbra, el volcán Batoer, y como una sombra vaga, el picacho Teloekbide Abang. Desde la carretera, retorcida en zigzag, para es- calar las cumbres, admirábamos los bancales que escalonaban las laderas. El sol arrancaba reflejos de la lámina de agua, germinadora del arroz. Dijéranse escalinatas de cristal, cuando como gradas descendían desde nuestros pies hasta las profundidades del valle; pero de lejos, en la montaña opuesta, las laderas pa-recían faldas hinchadas por gigantescos miriñaques, orladas de volantes escalonados. Más abajo, los cocoteros movían sus palmas, abanicándose con pereza tropical al soplo de una brisa suave; sus frutos colgaban como ubres prometedoras, y los bambúes gigantes se abrían en haces como las palmas de la corona de la Alteza de Inglaterra.

Todo lo vimos con el interés de una curiosidad infantil y el detenimiento de una madurez prematura: los templos abiertos de muros cuajados de una decoración minuciosa y barroca; los mercados llenos de animación y color local; los paisajes variados de la montaña y la llanura; todo, en suma, cuanto puede gozar el viajero que se detiene por unos días tan sólo en la paradisíaca isla de Bali.

\section{$\approx \approx \approx$}

El cuarto día de nuestra estancia en la isla, presenciamos en Denpásar las danzas rituales. Frecuentemente se reúnen ante el templo del lugar las bailarinas y los actores, interpretando a 
los sones del gamelán ${ }^{13}$ los bailes ofrecidos a los dioses.

Hemos aludido a la significación de la cultura india en la civilización balinesa; los exponentes actuales de aquella cultura reflejan cierta pureza en sus ceremonias y costumbres, acercándose más al modelo primitivo, que al seguido hoy en la misma India. No podemos aplicar este postulado al estado actual de las danzas dramáticorreligiosas de Bali, pues el momento presente puede y debe ser considerado como de evolución, no alcanzando el grado altísimo de simbolismo de este arte en la India, donde "la realidad artística coreográfica se ha estilizado hasta llegarse a una representación ideográfica de las siguientes altas concepciones de espíritu, ideas y sentimientos: Sringara, danza representativa de los seis sentimientos racionales, básicos de la creación; Vir, significación del valor y el heroísmo; Karuna, de la piedad y compasión; Adbhuta, del sentido de lo maravilloso; Hasya, de la risa; Bayhanaka, del miedo; Bibhatsa, sentido de lo grotesco; Raudra, de lo terrible; Shanti, de la paz; Dasya, de la devoción; Sakhya, de la amistad; Watsalya, representativo de la ternura paternal; Madhura, del amor entre cónyuges". ${ }^{14}$

Los tratadistas indios del arte de la danza divídenla en dos sistemas diferentes: Margi y Best; al primero pertenecen exclusivamente los bailes religiosos celebrados en los templos ante los dioses; los del se-gundo son los representados ante los príncipes, con un fin exclusivamente profano.

Las danzas balinesas ejecutadas aisladamente por la danza en si forman un número aparte. Los movimientos y pasos que constituyen el baile son interpretados como parte integrante de la representación dramática. En este sentido no podemos encontrar en la historia del teatro mundial nada más semejante a las danzas dramáticorreligiosas de Bali, que los Místenos religiosos de la Edad Media, base de los teatros nacionales europeos.

En la hermosa isla de la Malasia, los argumentos son historias mitológicas -modernas muchas de ellas-, relatos ampliados de la rica cantera de las leyendas indias. En los Místenos, Autos, Miracleplays, Geistliche Schauspiele o Sacre lieppresentazione; los temas dramáticos son episodios de la vida del Salvador. Por lo tanto, en Europa, como en aquel rincón de la Insulandia, la base de tales representaciones escénicas es y fue religiosa; pues religión y mitología están unidas íntimamente en Bali. Este es el hecho fundamental, aparte de otros no menos representativos, como ser las inmediaciones del templo o el templo mismo el escenario de autos, dramas y danzas.

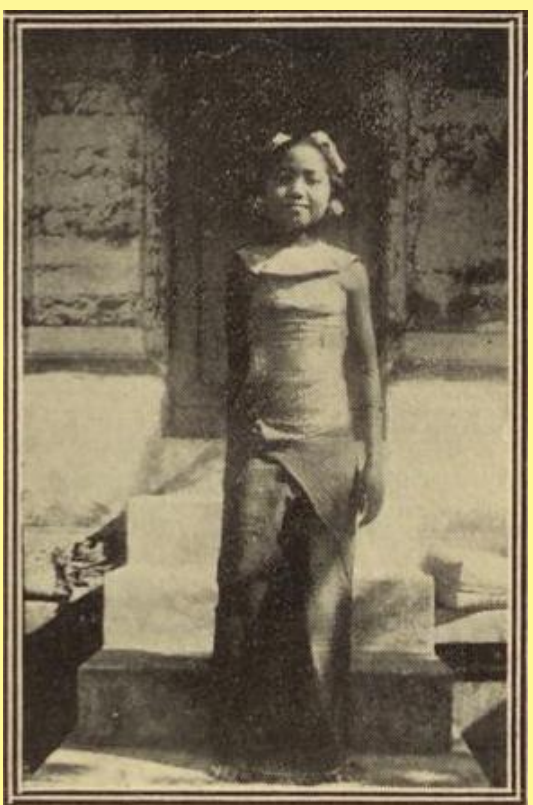

La benjamina de las bailarinas

Ante el templo de Denpásar, frente a sus tapiales, labrados en las historiadas sobrepuertas carátulas, idolillos, pajarracos y hojarasca, trabajados primorosamente en la piedra de arenisca roja y a la sombra de una hermosísima chumbera de Bengala, esos árboles gigantescos que forman una

${ }_{13}$ Nombre con que se designan las agrupaciones musicales u orquestas en Bali y Java

14 Véase Nritanjali Hindu Dancing, by Sri Ragini. New York, 1928. 
verdadera selva: troncos recios unidos al más corpulento y central por un complicado sistema natural de cables vegetales y lianas; ramas sujetas al suelo por otras que, cayendo verticalmente, horadan la tierra para convertirse en raí- ces, al mismo tiempo en soportes y tirantes de aquel gigante vegetal. Nos congregamos en este lugar forasteros y vecinos para presenciar las danzas y representaciones dramáticas.

El gamelán u orquesta nacional formó en cuadro, dejando un espacio ancho en el centro. Los músicos colocaron ante si sus instrumentos, sentándose en el suelo sobre esterillas finas; aquel patio, en cuadro, también estaba esterado. Todos los músicos parecían jóvenes; iban desnudos de la cintura para arriba y cubrían con una especie de pantalón-falda de batik ${ }^{15}$ las extremidades abdominales; se tocaban con unos gorros parecidos a los llamados de legionario, o sean pañuelos del mismo batik, anudados de manera que queden convertidos en pequeños bonetes. Otras veces se los sujetan como nuestros baturros, dejando al aire casi toda la cabeza.

Observé despacio todos y cada uno de los instrumentos del gamelán: en primer lugar, los tres gongs enormes, huecos sus vientres de cobre, pendientes de sencillos bastidores; los kedang, en número de dos - tamboriles en forma de barrilillos, largos, de poco diámetro -; los trompong y gambang, montados sobre mueblecillos bajos de madera, con profusión de tallas de un barroquismo no muy lejano al nuestro y pintados de rojo con filetes dorados. El trompong es el instrumento más importante del gamelán: una serie de cazuelas de distintos tamaños, según la nota que han de producir al ser golpeadas por los palillos empuñados por el músico, se alinean sobre el decorado pupitre; generalmente cada gamelán tiene dos trompong: el principal de ellos es tocado por el músico mayor, al que podríamos calificar de director de orquesta. El gambang no es sino un xilófono: tiene fijas en el mueble hasta diecinueve piezas de madera, planas u oblongas, que producen las distintas notas cuando son golpeadas por los palillos del ejecutante. Este instrumento da el «aire» a la composición.

Muy importante y aparatoso es también el gender. Consiste en un bastidor de madera, del que penden generalmente doce piezas de bronce u otro metal; un tubo de bambú actúa como caja de

${ }_{15}$ Especie de percal fino, con dibujos caprichosos de distintos colores. El batik más apreciado procede de Djokjakarta (Java Central). resonancia. En Denpásar faltaban algunos instrumentos de menor importancia, los cuales, sin ser esenciales, figuran en otros gamelanes más completos.

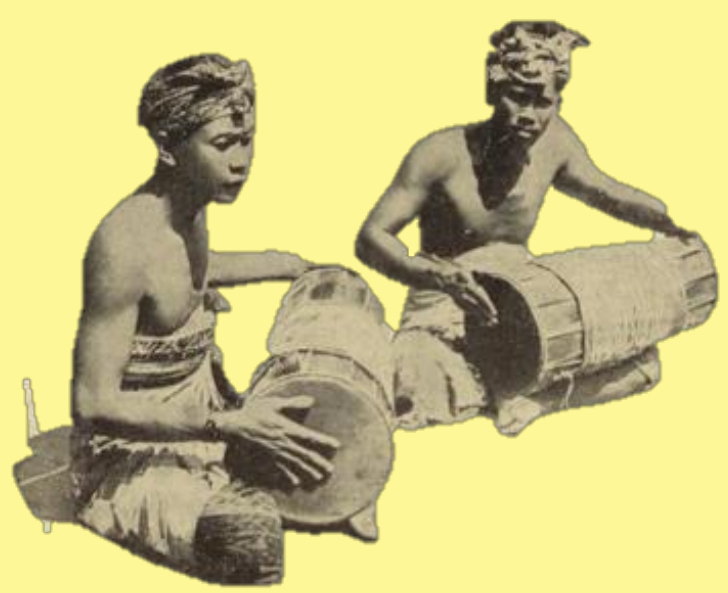

Tocando el kedang

El rahab es, por su tamaño, parecido a nuestros violines. El ejecutante se coloca el instrumento entre las piernas acompañando con sus notas la composición. El gender panerus, pequeño gender; el tjelempung, cítara o arpa inclinada sobre un bastidor de madera, cuyas notas vigorizan y animan la música del gamelán; y los siding, especies de flautas de distinto diapasón: siding pelog y siding slendro. La primera parte 
del programa fue la obertura interpretada por el gamelán: los toques del gender, tenues, como campanas de relojes del siglo XVIII o notas de caja de música; luego intervino el trompong, elevándo-se la frase musical con resonancias de órgano, atropellándose los sonidos. Sin reparar con la vista en los músicos, me imaginaba a los del trompong golpeando las cacerolas, casi saltando de unas a otras los palillos, para producir las distintas notas. Resonaban luego más claras las del gambang: ágiles, sin ampulosidades de cajas de resonancia, matizadas monótonamente con el acompañamiento del kedang al contacto los parches con los dedos rígidos del ejecutante. ${ }^{16}$

Terminado el concierto, salió al cuadro que dejaban libre los instrumentos uno de los músicos, tañedor de uno de segundo orden. Ya en aquel escenario, comenzaron sus danzas. Para nosotros, occidentales, para quienes el baile tiene cuando más uña función estética, pero nunca ritual y sagrada, aquellos movimientos se nos antojaban afeminados y artificiosos; sin embargo, sus contracciones faciales, sus brazos agitados primeramente, jugando después con un abanico, que se pasaba de mano a mano; las contorsiones al sentarse sobre la estera; en una palabra, todas sus acciones respondían a un alto simbolismo religioso. El origen divino de las danzas de la India da a las balinesas, de las que proceden, un origen divino también.

En el XV libro del Código de los Vedas se habla del Natía Shastra y del sabio Bharata, «jefe de los escenarios de los Dioses», quien recibió del propio Brahma, el Creador, la revelación de las artes del drama, la música y el baile para alegría del Universo. En consecuencia, cada movimiento, cada gesto, cada actitud tiene una representación simbólica; el citado libro de la gran bailarina india Sri Ragini, describe hasta dieciocho formas distintas de disponer las manos; cada una de ellas representa seres de la mitología brahmánica, actitudes de los dioses, etc. De repertorio tan vario sólo citaremos aquí la posición llamada Adoha-Chandra (las palmas para adentro y los dedos entrelazados), por representar al fantástico animal Garuda, deidad zoomorfa, de gran importancia en la Mitología balinesa, según tendremos ocasión de comprobar más adelante. ${ }^{16}$ Para aquellos lectores que deseen tener una idea más exacta de la música balinesa reproduciré aquí las palabras de la
señora doña Emilia Scott, competentísima en asuntos musicales, publicadas en la revista InterOcean, en agosto de 1930. Dice así: «Las composiciones javanesas y balinesas son contrapunteadas, polifónicas y se adaptan a leyes fundamentales. Son usados los sistemas primario, binario y rondó. Un grupo de instrumentos interpreta un motivo lento, pesado y
La intervención del bailarín, notabilísima en las danzas indias (Nayaka), ha quedado reducida a una forma episódica en Bali, aunque interesante, para poder establecer la relación existente entre ambas.

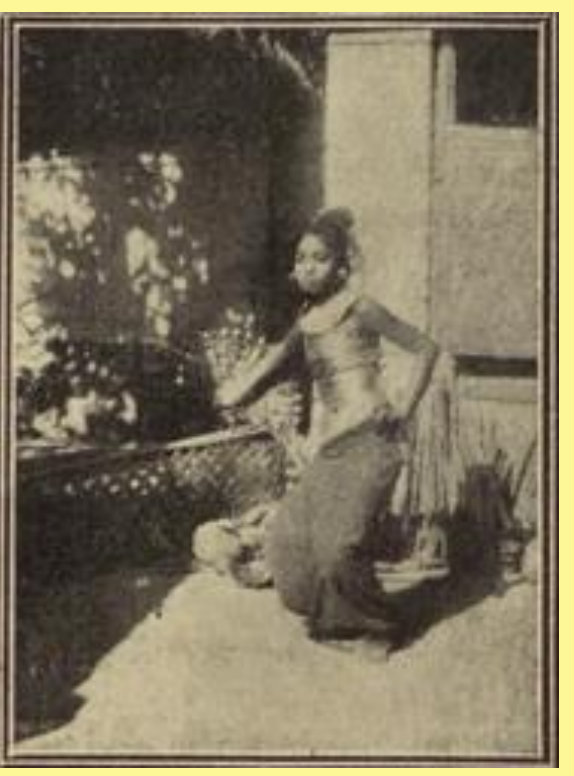

Una bailarina

En seguida comenzó la parte verdaderamente teatral. Es de advertir que en las veladas se representan una parte o acto de varias de las leyendas escénicas del repertorio nacional; no

esquemático; en tanto que otro parafrasea el mismo, y aun uno tercero le florea libremente.... Las composiciones siempre terminan al unísono.» 
suelen interpretarse íntegras, como sucede también, por ejemplo, en el Teatro Japonés de Muñecas de Osaka. ${ }^{17}$

El gamelán se replegó a uno de los rincones para dejar libre el mayor espacio posible; los espectadores, lo mismo los turistas, extraños a aquella sociedad piadosa y primitiva, que los naturales, hombres en su mayoría y chiquillos ligeros de ropa, ensanchamos el rectángulo formado antes dentro de los músicos. Llegaron las bailarinas de Denpásar. Es muy interesante hacer notar que en Bali, muchachas y jóvenes, actúan durante un período determinado de tiempo -tres años generalmente- como agregados al templo de la ciudad, pueblo o aldea donde viven. Las niñas, desde muy tierna edad, se ejercitan en los bailes que luego han de representar con un carácter religioso, pero sólo hasta los catorce años; pasada esta edad, no pueden oficiar «ante los dioses». Es innecesario advertir que en Bali, país tropical, las muchachas a esa edad son verdaderas mujeres, y se envejecen apenas pasan de los veinte años.

Antes de comenzar el espectáculo habíamos concurrido todos los viajeros a unas cabañas espaciosas y limpias, próximas al templo, para ver el tocado de aquellas girls del ballet ritual. Entonces terminaban su toilette, dando los últimos toques al maquillage: no hay exageración alguna en esta frase, pues las muchachas recubren por entero su rostro de unos polvos-pomada, preparación de tocador - producto importado seguramente-, de tono moreno, aunque distinto del color natural de su tez; suprimiendo de la misma manera la brillantez sudorosa de la piel. Se ayudaban mutua- mente en estas y otras tareas.

Lo que más me llamó la atención del tocado de aquellas bailarinas del templo fue contemplar cómo «se hacían» las cejas: aún llegué a tiempo para ver a alguna afeitándoselas, para luego dibujarlas con habilidad de coquetuelas occidentales, sirviéndose para ello de un pincelillo y de tinta china. El trazo grueso en el entrecejo se prolongaba finamente hasta casi llegar a las sienes.

Con alboroto propio de la temprana juventud, terminaban su tocado; se alhajaban con sus joyas pesadas, impropias de aquellas mujercitas menudas: pendientes enormes, cilíndricos, rematados en sus extremos por piedras - cristales tal vez- que agujereaban los lóbulos de las orejas, abriendo en ellos grandes redondeles; ajorcas y brazaletes.

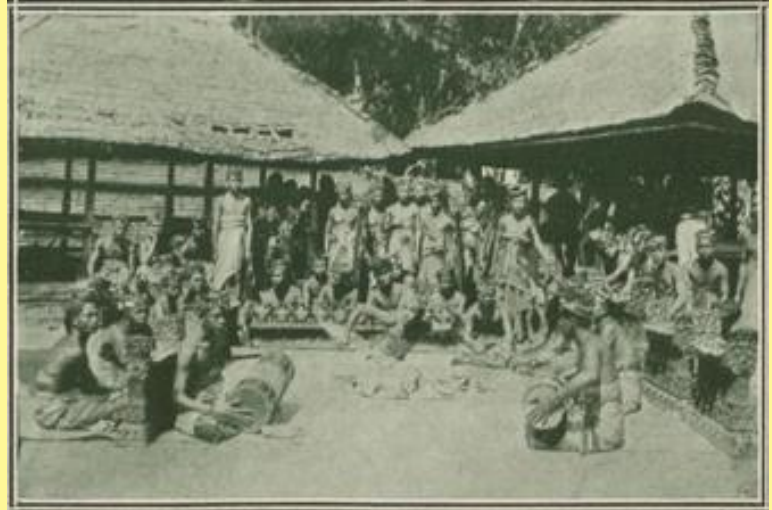

El Gamelán

Los trajes de ceremonia eran interesantes. Tocaban sus cabezas con capillos de cuero fino, rematados en diademas radiales como coronamientos. El capillo es una de las prendas más suntuosas de la indumentaria de las bailarinas, pues la piel, de consistencia suficiente para mantener la rigidez necesaria, tiene calados por vía de adornos, que convierten esta lujosa prenda en un verdadero encaje; aumentando su vistosidad los colores vivos, dorado y rojo, generalmente, y las piedras menudas del frontis.

El traje es más sencillo: una pieza de batik, desceñida por abajo y sujeta a las caderas, las envolvía las piernas; ancha faja de tejido de pulpa, con reflejos dorados, le sostenía los pechos, recogiéndose por bajo de los brazos. Un cinturón

${ }_{17}$ Véase crónica VIII. 
metálico casi colgaba en el arranque de las caderas sobre el arrugado justillo, que parecía de papel. Dejarían descubiertos los hombros y la garganta a no ser por un peto redondo, también de cuero, semejante en su vistosidad al complicado casco; quedaban libres de toda vestimenta los brazos, caídos, ajustados al cuerpo o en forzada pirueta casi grácil.

Dio comienzo la segunda parte de la representación, es decir, la parte escénica del espectáculo. El gamelán tocaba su música mística con resonancias de órgano en el ambiente caldeado por los golpes de los gongs.

Comenzaron a evolucionar dos muchachas, dijérase que gemelas; seguramente las más jóvenes del ballet. Con ser precoz la naturaleza en los trópicos, las existencias de aquellas dos bailarinas apenas si se abrían a la vida como capullos. Se movían gráciles, agitándose a veces como si se retoraieran en el estertor de una agonía musical. Doblaban las caderas con flexibilidad, sin contorsiones; con brazos y manos tejían el complicado simbolismo de las danzas reveladas por Brahma. En el transcurso de la interpretación, una de ellas quedaba inmóvil, reposaba sentada con expresión de tristeza mística; mientras, la otra jugaba con sus posturas, que parecían mimosas por la ternura de su edad. De nuevo evolucionaban juntas, parecían perseguirse: una de ellas ajustaba las palmas de las manos a las caderas de su gemela, recorriendo así el ámbito sombreado por el árbol colosal.

Más tarde leí el argumento de aquella pantomima, digna de un teatro moderno. Se llama Lélong. Un príncipe distinguido y gentil consigue entrar en un harén, buscando a su amada. Allí la encuentra, y la invita a mostrar su evolución espiritual por sucesivas transformaciones. Ella se enoja y queda convertida primero en un pajarraco y luego en una Rangda: la bruja de la mitología balinesa. Al príncipe le agradan esos sucesivos estados tan diferentes, como una muestra de su exquisita espiritualidad. Y termina la pantomima con la unión de ambos en felicísimo matrimonio.

Terminada la representación de Lelong procedióse, tras corto entreacto, a la de otra pieza del teatro balines, escrita no ha muchos años. Llámase Djanger. Salió primero una actriz caracterizada como príncipe que quedó sentada en medio de la escena. Comparecieron luego dieciséis guerreros y otras tantas danzarinas. Bailaron agitándose convulsivamente; sentáronse después en cuadro, moviendo los brazos al compás de la música. Representaba este cuadro al Rey Arjuna, sus guerreros y las esposas de éstos.
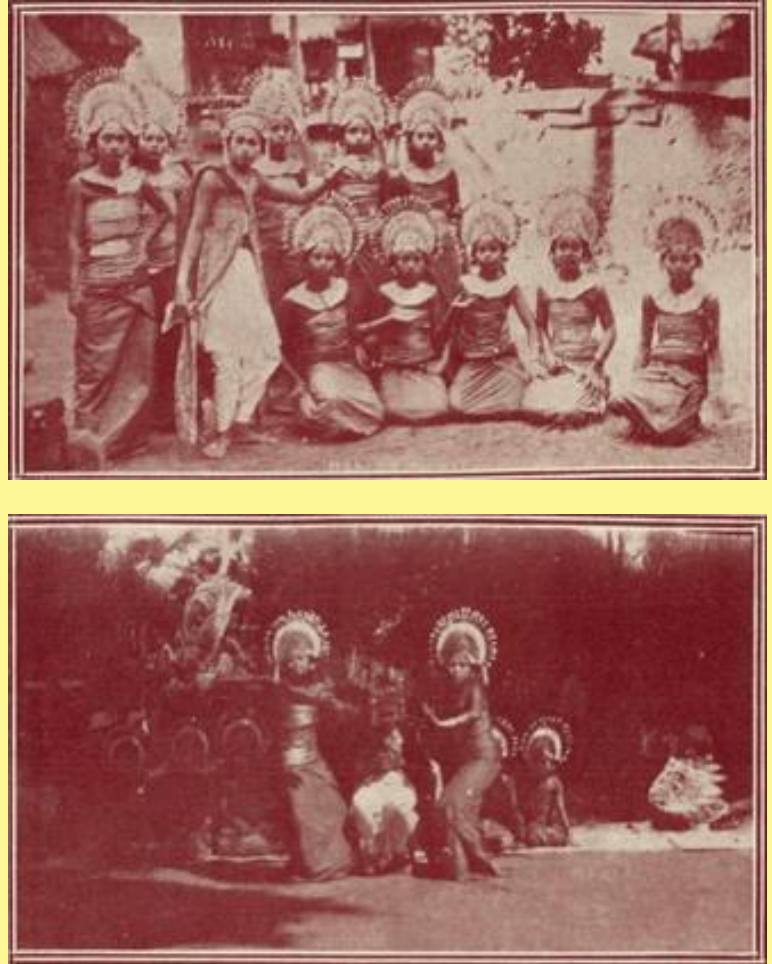

Bailarinas en el templo de Denpásar Y Dos bailarinas de Lélong.

Aquella parte fue sólo un ballet-pantomima; en la segunda quedó solo el Rey. Este cuadro lleva por nombre La Meditación de Arjuna. En la montaña se entrega a las contemplaciones idealistas de su 


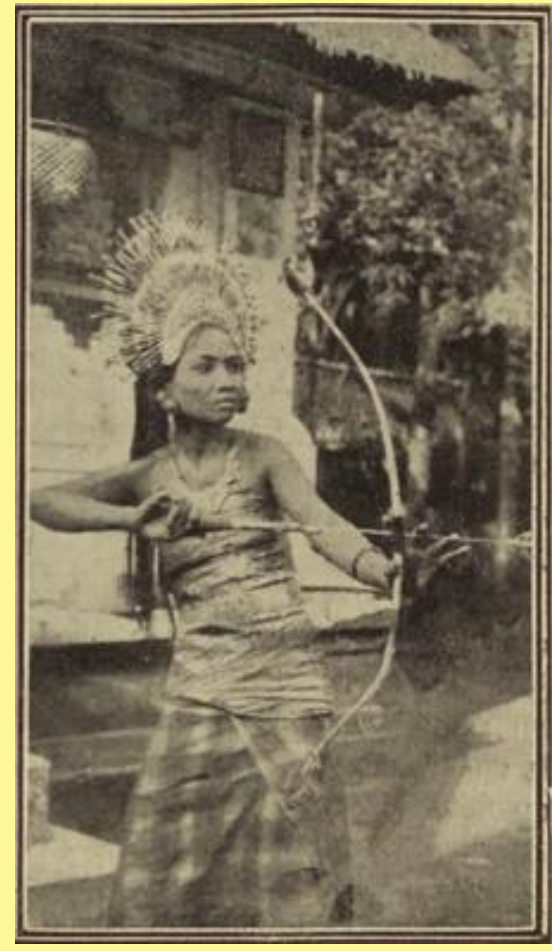

Una escena del Tjalon-arong. espíritu elevado. Vírgenes hermosísimas vienen a turbarle, como una tentación, interrumpiendo sus elucubraciones; en aquel momento preséntase el monstruoso pajarraco Garuda. Arjuna se dispone a la lucha; requiere el arco y sus flechas sagradas, las mismas que usó Rama, el héroe venerado y semilegendario de la épica India, ${ }^{18}$ y con tales armas da muerte al monstruo que ponía en peligro su vida.

La interpretación responde a un sentido realista y melodramático: elementos ambos muy característicos del teatro balinés. En la escena de la Meditación, el Rey o Príncipe Arjuna cantaba en voz queda. Su voz atiplada se modulaba, prolongándose en lamentos de saeta, con el acompañamiento vago de una flauta (suling pelog o siding slendro) y el tan-tan monótono del bedang, semejante a los panderos de los gitanos y vagabundos que recorren el mundo haciendo bailar al oso.

El personaje Arjuna, era interpretado por una de las bailarinas del templo, escogida entre las más antiguas, no tan sólo por tratarse de un papel difícil, sino también porque encarne mejor el personaje, héroe de leyenda. Su traje difería del ya descrito en sustituir el peto redondo por un collar-pendantif; el tocado, sin afectar al lujoso capillo de cuero, dejaba caer el pelo, suelto, poco abundante y lacio, hasta la cintura. El monstruo Garuda lo interpretaba un actor que, con alas de tela pintada, representando plumas, y una máscara de animal imaginario, hacía las veces de monstruo fantástico sin grandes artificios o extravagancias.

${ }_{18}$ Rama es el protagonista del gran poema épico Ramayana, cuyas hazañas describe la inmortal obra. Como el Mahabarata, y prescindiendo del gran valor literario de una y otra, la historiografía tradicional las ha considerado como fuentes tenido por absolutamente fantásticas. Al P. Heras, director del Seminario de Estudios Históricos, dependiente del Saint Xavier's College, de Bombay, espanol y jesuita insigne, que tan alto pone el prestigio de nuestro país, se debe una posicín ecléctica en este pleito de
crítica histórica de la India. Por su iniciativa y bajo su dirección uno de sus discípulos está preparando su tesis doctoral
El fin de tiesta fue la representación de las últimas escenas del drama balines llamado Tjalon-arong, pues de no haber omitido escena alguna, la función se hubiera prolongado hasta bien entrada la tarde, habiéndose comenzado a las ocho de la mañana con la obertura del gamelán. La historia completa de este drama es la siguiente: Una famosa bruja reúne a sus nueve hijas, hermosas criaturas, para darlas cuenta de la acusación que echan sobre ella las gentes de la vecindad. La Rangda afirma ante las nueve muchachas la verdad de las murmuraciones de las gentes: es cierto que ella roba los cuerpos de los cadáveres depositados en el cementerio, y después de descuartizarlos, se alimenta con ellos. Sin embargo, les ruega que no traicionen su sangre y prometan serla fieles. Entonces, las convierte en nueve brujas, y al retirarse la madre a descansar en su cueva, la mayor de las hijas, poseída del genio del mal, víctima del encantamiento de la vieja Rangda, arenga a sus hermanas para que 


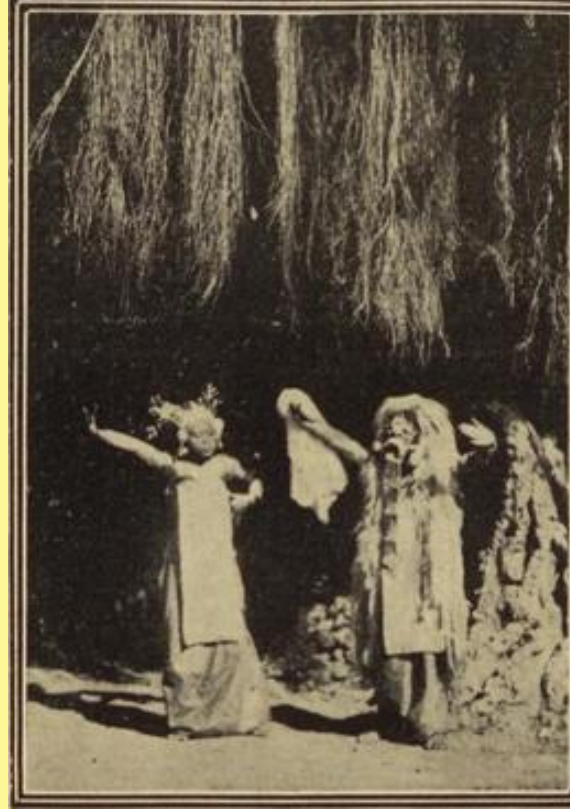

Una escena del Tjalon-arong

salgan dos a dos y busquen como aquélla su alimento entre los muertos.

Entre tanto, el Rey del país envía a un príncipe con la orden de capturar y dar muerte a la nefasta bruja, en castigo a sus maldades. El hijo del soberano, seguido de dos acompañantes, llega a la puerta de la cueva, morada de la Rangda. - Con esta escena dio comienzo la representación que yo presencié -

La monstruosa criatura, verdadero buitre humano, permanecía casi invisible en la sombra del árbol colosal, cerca de la maraña de cables vegetales, troncos y lianas de estropajosa cohesión. De esta manera se pre- tendía simular que estaba escondida en la cueva.

El Príncipe, que encarnaba, como en el papel de Arjuna de la pieza anterior, en una muchacha, pero más joven, avanzaba resueltamente. La bruja salió de su retiro para cortarle el paso. El héroe la descubrió y despojóla de un paño con que parecía empeñada en velar su rostro; empuñando el kris19 la persiguió. Dijérase que triunfaría en su noble lucha; sin embargo, la Rangda, más astuta que su joven enemigo, protegida de los golpes de la acerada arma por la pelambrera que la cubría como horrenda capucha, y utilizando cual arma ofensiva el colmillo que asomaba a sus fauces, como el de un monstruo montaraz, conseguía alcanzarle, y desarmándole le daba muerte; llevando luego su cuerpo inerte colgando de sus brazos, más bien garras de diabólica criatura.

El teatro balines, como otros muchos de la dramática universal, se vale de caretas sólo para la interpretación de ciertos papeles; a diferencia de esos otros aludidos (carátulas romanas, Teatro Nöh, del Japón, etcétera), usados de una manera regular. En Bali, las máscaras puede decirse sustituyen a las caracterizaciones de nuestros actores. La usada en la representación de la Rangda

19 Arma blanca malaya, de hoja con bordes ondulados, que produce heridas difíciles de curar. no es una careta humana, sino de monstruo caprichoso, con ciertos rasgos antropomorfos, de cuya boca sale el tremendo colmillo, arma terrible de la fatídica bruja. La indumentaria no podía apreciarse fácilmente: la larga cabellera, representada por luengas marañas de pelos blancos, con apariencia de plumas, ocultaba casi por entero sus vestiduras.

Aún creo escuchar el grito destemplado del infeliz Príncipe, víctima de la voracidad de la Rangda: más estridente que los toques postreros del gender, finales de la sinfonía del gamelán.

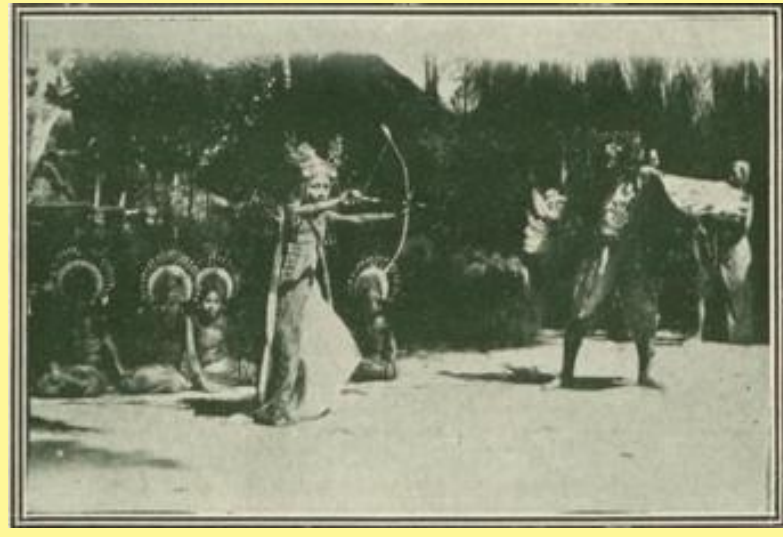

El príncipe Arjuna matando al pájaro mítico Garuda. 


\section{BIBLIOGRAFÍA RECOMENDADA}

- Adriana y Carpenter, Bruce W., Miguel Covarrubias: sketches: Bali-Shanghai. Yakarta, Red \& White Publishing with Island Arts, 2012.

- Arimbawa, I. Made Gede. "Exploitation of Bali Traditional Symbols on Today's Design”, Cultura: International Journal of Philosophy of Culture \& Axiology, vol. 8, n², 2011, pp. 213-214.

- Atkins, Gary. Imagining gay paradise: Bali, Bangkok, and cyber-Singapore. Hong Kong, Hong Kong University Press, 2012.

- Ayala Canseco, Eva María (coord.). Homenaje nacional, Miguel Covarrubias: cuatro miradas = National homage, Miguel Covarrubias: four visions. México D.F., Editorial RM, CONACULTA y Museo Soumaya, 2005.

- $\quad$ Barley, Nigel. Island of demons. Singapur, Monsoon Books, 2009.

- Basset, Catherine. Músicas de Bali a Java: el orden y la fiesta. Tres Cantos, Akal, 1999.

- $\quad$ Baum, Vicki. Amor y muerte en Bali. Barcelona, Planeta, 1959.

- Booz, Patrick R. Nuestro mundo en color: Bali. Madrid, Ediciones J

- Campbell, Siobhan. "Craft and the archive: Museum collections and memory in a Balinese village”, Craft• Material• MeMory, vol. 6, 2014.

- Carpenter, Bruce W. W.o.j. Nieuwenkamp: First European Artist in Bali. Abcoude: Uniepers, 1997.

- Chegaray, Jaques. Bonheur à Bali, lîle des tabous. París. Amiot Dumont, 1953.

- Cocteau, Jean. "Food por the Gods" en Gocher, Jill. Secret Bali: Behind the Tourist Facade. Kuta, Now! Bali Publications, 2012.

- Covarrubias, Miguel. La Isla de Bali. Palma de Mallorca, M. de Olañeta, 2012.

- d'Oliveira Martins, Maria Manuela. Asian shadows. Lisboa, Fundação Oriente, 2013.

- Davison, Julian, Introduction to Balinese Architecture. Singapur, Periplus, 2003.

- $\quad$ de Jasper, J. E. y Pirngadie, Mas. De Inlandsche Kunstnijverheid in Nederlandsch Indië. La Haya, Mouton \& Co, 1912.

- de Marval, Gaspard. Ukiran: Essai de classification des poignées de kris de l'archipel indonésien. Chalet-à-Gobet, G. de Marval, 1993.
- García-Noriega y Nieto, Lucía (coord). Miguel Covarrubias: homenaje. México D.F., Centro Cultural/Arte Contemporáneo, 1987

- Gorer, Geoffrey. Bali and Angkor: a 1930 s pleasure trip looking at life and death. Oxford, Oxford University Press, 1987.

- Joefer, Hans J. (ed.) Bali. Madrid, El País S.A. / Aguilar S.A., 1990.

- Hughes, Alice. "Our Beaches to Adopt Bali Modes”, New York Journal and American, jueves 30 de diciembre de 1937.

- Juynboll, Hendrick Herman. Kawi Balineesch - Nederlandsch glossarium: op het oudjavaansche Ramayana. La Haya, Martinus Nijhoff, 1902.

- Koke, Louise Garrett. Our Hotel in Bali: How two young Americans made a dream come true: a story of the 1930s, Wellington, January Books, 1987.

- Krause Gregor. Bali: volk, land, tanze, feste, tempel. Munich, Georg Muller Verlag, 1926

- Lindsey, Timothy. The Romance of K'tut Tantri and Indonesia. Sheffield, Equinox Publishing, 1997.

- Medina, Andrés. "Miguel Covarrubias y el romanticismo en la antropología”, Nueva Antropología, v. I, $\mathrm{n}^{\circ}$ 4, 1976. pp. 11-42.

- Mowbray, Nicole, "In search of an exotic isle: Beyond de Eat, Pray, Love phenomenon in Beautiful Bali”, The Mail On Sunday, 21 de junio de 2012. 
- Moss, Allyn. Lessons in living: the life and the discoveries of Margaret Mead. Nueva York, Ladder, 1966.

- Navarette, Sylvia y Tovalín Ahumada, Alberto. Miguel Covarrubias: retorno a los origenes = a return to origins. Mexico D.F., Consejo Cultural UDLA Puebla / CONACULTA-INAH, 2004

- Nieuwenkamp, W.O.J. Bali En Lombok: zijnde verzameling geïllustreerde reisherinneringen en studies omtrent Land en Volk, Kunst en Kunstnijverheid. Amsterdam, De Zwerver.

- Osnes, Beth. The Shadow Puppet Theatre of Malaysia: A Study of Wayang Kulit with Performance Scripts and Puppet Designs. Jefferson, McFarland \& Co., Publishers, 2010.

- Paintings, Water Colors, Drawings of Bali by Miguel Covarrubias. Nueva York, Valentine Gallery, 1932.

- Palacios, Julio. Filipinas, orgullo de España: un viaje por las islas de la Malasia. Zaragoza, Diputación General de Aragón, 1998.

- Peiró Márquez, Marisa. "Asia-Pacífico en la obra del artista mexicano Miguel Covarrubias (1904-1957): una introducción”, en Castán Chocharro, Alberto (coord.), Jornadas de Investigadores Predoctorales: La Historia del Arte desde Aragón. Zaragoza, Prensas de la Universidad de Zaragoza, 2016, pp. 311-318. Peiró Márquez, Marisa. “Asia-Pacífico en la obra del artista mexicano Miguel Covarrubias (1904-1957): una introducción”. Tesis Doctoral de la Universidad de Zaragoza, 2018. Disponible en línea en: https://zaguan.unizar.es/record/77093?ln=es

- Poniatowska, Elena, Miguel Covarrubias: vida y mundos. México D.F., Ediciones Era, 2004.

- Powell, Hickman, The Last Paradise. Nueva York, J. Cape and H. Smith, 1930.

- Pringle, Robert. A short history of Bali. Crows Nest, Allen \& Unwin, 2004.

- Sitompul, Jojor Rio. Visual and textual images of women: 193os representations of colonial Bali as produced by men and women travellers. Tesis doctoral de la Universidad de Warwick, 2008.

- Skeat, Walter W. Malay Magic: Being an Introduction to the Folklore and Popular Religion of the Malay Peninsula. Londres, Macmillan, 1900.

- $\quad$ Spies, Walter y de Zoete, Beryl. Dance and Drama in Bali. Londres, Faber and Faber, 1938.

- Tantri, K'tut. Revolt in Paradise. Nueva York, Harper, 1960

- Vickers, Adrian. Bali: Paradise Created. Penguin Books, 1989.
- Vickers, Adrian. Balinese Art: Paintings and Drawings of Bali, 180o-2010. Varsovia, Polish Modern Art Foundation, 2016.

- Wallace, Alfred Russel. The Malay Archipelago: the land of the orang-utan and the bird of paradise: a narrative of travel with studies of man and nature. Londres, Nueva York, Macmillan and Co, 1894.

- Williams, Adriana y Carpenter, Bruce W., Miguel Covarrubias: Sketches: Bali Shanghai. Yakarta, Red \& White Publishing with Island Arts, 2012.

- Williams, Adriana y Chong, Yu-chee. Covarrubias in Bali. Singapur, Editions Didier Millet,

- Williams, Adriana. Covarrubias. Austin, University of Texas Press, 1994. 

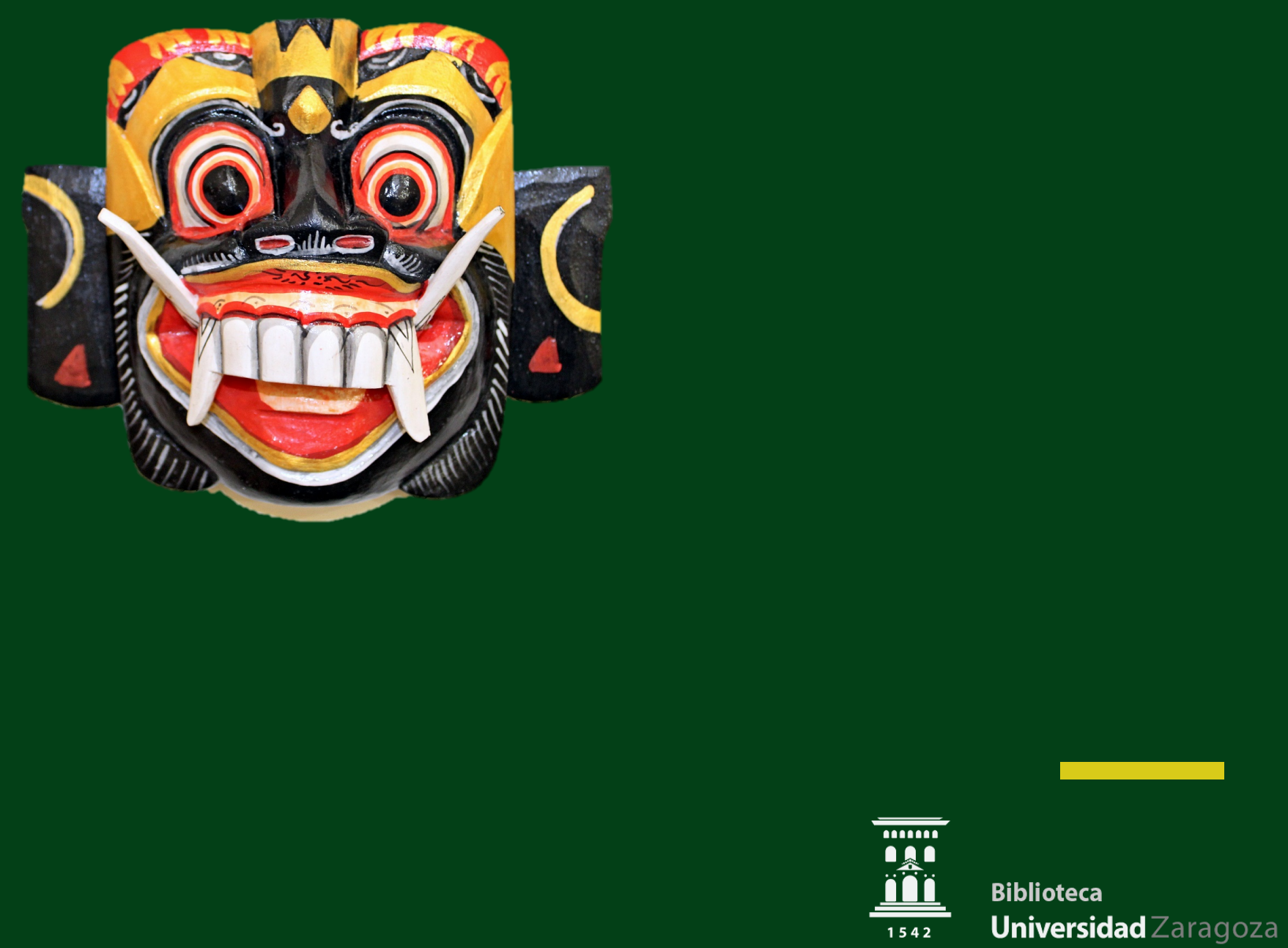